Faculdade de Medicina Veterinária e Zootecnia Departamento de Nutrição e Produção Animal

MARIANA ROSÁRIO FREITAS LOPES

Carne bovina reestruturada com óleo de canola e antioxidante: desenvolvimento e atributos sensoriais 


\section{Carne Bovina Reestruturada com Óleo de Canola e Antioxidante:}

desenvolvimento e atributos sensoriais

Dissertação apresentada ao programa de PósGraduação em Nutrição e Produção Animal da Faculdade de Medicina Veterinária e Zootecnia da Universidade de São Paulo para obtenção do título de mestre em Ciências

\section{Departamento:}

Nutrição e Produção Animal

Área de concentração:

Nutrição e Produção Animal

Orientadora:

Prof $^{a}$. Dr ${ }^{a}$. Angélica Simone Cravo Pereira 
Autorizo a reprodução parcial ou total desta obra, para fins acadêmicos, desde que citada a fonte.

DADOS INTERNACIONAIS DE CATALOGAÇÃO-NA-PUBLICAÇÃO

(Biblioteca Virginie Buff D’Ápice da Faculdade de Medicina Veterinária e Zootecnia da Universidade de São Paulo)

Lopes, Mariana Rosário Freitas

Carne Bovina Reestruturada com Óleo de Canola e Antioxidante: desenvolvimento e atributos sensoriais / Mariana Rosário Freitas Lopes. -2012.

$100 \mathrm{f}$ : : il.

Dissertação (Mestrado) - Universidade de São Paulo. Faculdade de Medicina Veterinária e Zootecnia. Departamento de Nutrição e Produção Animal, Pirassununga, 2012.

Programa de Pós-Graduação: Nutrição e Produção Animal. Área de concentração: Nutrição e Produção Animal.

Orientador: Profa. Dra. Angélica Simone Cravo Pereira.

1. Bife reestruturado. 2. Eritorbato de sódio. 3. Canola. 4. Textura. 5. Oxidação lipídica. I. Título. 


\section{Comissão de Ética no uso de animais}

\section{CERTIFICADO}

Certificamos que o Projeto intitulado "Carne bovina reestruturada com transglutaminase e antioxidante natural: desenvolvimento e atributos sensoriais", protocolado sob o $\mathrm{n}^{\circ} 2143 / 2011$, utilizando 144 (cento e quarenta e quatro) amostras de carne bovina, sob a responsabilidade do(a) Profa. Dra. Angélica Simone Cravo Pereira, está de acordo com os princípios éticos de experimentação animal da "Comissão de Ética no uso de animais" da Faculdade de Medicina Veterinária e Zootecnia da Universidade de São Paulo e foi aprovado em reunião de 04/5/2011.

We certify that the Research "Restructured meat with transglutaminase and natural antioxidant: development and sensory attributes", protocol number 2143/2011, utilizing 144 (one hundred forty four) sample bovine meat, under the responsibility Profa. Dra. Angélica Simone Cravo Pereira, agree with Ethical Principles in Animal Research adopted by "Ethic Committee in the use of animals" of the School of Veterinary Medicine and Animal Science of University of São Paulo and was approved in the meeting of day 05/04/2011.

São Paulo, 05 de maio de 2011.

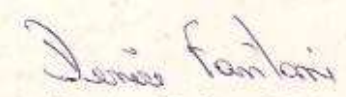

Profa. Dra. Denise Tabacchi Fantoni Presidente 


\section{FOLHA DE AVALIAÇÃO}

Autor: LOPES, Mariana Rosário Freitas

Título: Carne bovina reestruturada com óleo de canola e antioxidante: desenvolvimento e atributos sensoriais

Dissertação apresentada ao programa de Pós-graduação em Nutrição e Produção Animal da Faculdade de Medicina Veterinária e Zootecnia da Universidade de São Paulo para obtenção do título de mestre em Ciências

Data;

1

\section{Banca Examinadora}

Prof. Dr.

Instituição: Julgamento:

Prof. Dr.

Instituição: Julgamento:

Prof. Dr.

Instituição: Julgamento: 
Com muito amor aos meus pais Inês e Luiz Que me deu a vida e me ensinou a vivê-la com dignidade. Por toda dedicação, apoio e amor, em cada etapa conquistada. Obrigada por acreditarem em meus sonhos. Ao meu querido irmão Guilherme que mesmo longe se faz presente, obrigada pela amizade.

- A vocês dedico este trabalho - 


\section{AGRADECIMENTOS}

Em especial à Deus, pelo dom da vida, por guiar meus passos e abrir caminhos para que tudo em minha vida se realizasse.

A minha querida orientadora, $\operatorname{Prof}^{\mathrm{a}}$. $\mathrm{Dr}^{\mathrm{a}}$. Angélica Simone Cravo Pereira, pela amizade, orientação, ensinamentos, paciência, incentivos e por acreditar em mim como profissional.

A Prof ${ }^{a}$. Dra . Mônica Roberta Mazalli, pela orientação e colaboração na realização deste trabalho.

A Faculdade de Medicina Veterinária e Zootecnia da Universidade de São Paulo - Campus Pirassununga, em especial a todos os professores do curso de pós-graduação, pelos ensinamentos e realização deste curso.

Ao Prof. Dr. Júlio Cesar de Carvalho Balieiro pelos ensinamentos e auxílio nas análises estatísticas.

Ao Prof. Marcos Antonio Trindade pelos ensinamentos.

Ao Prof. Dr. Pedro Eduardo de Felício, Sérgio e Mariana Guizzo pela colaboração e disponibilidade dos equipamentos para as análises de textura.

As estagiárias Stephanie, Mariana e Débora pelo auxílio e dedicação neste trabalho.

À equipe de laboratório de Bromatologia e Tecnologia de Produtos de Origem Animal desta faculdade, em especial ao pelos ensinamentos e colaboração.

As Empresas VPJ e All taste, pela cooperação e apoio dedicado, em especial ao Gerente Geral Antônio Augusto pela compreensão, apoio e amizade.

Ao funcionário João Paulo da seção de pós-graduação por todo auxílio, atenção e empenho na realização de suas tarefas.

Ao Caio César Gonçalves pelo apoio e paciência.

Aos amigos de pós-graduação pelas alegrias, descontração e apoio.

A todas as pessoas que de alguma maneira, tornaram possível a realização deste trabalho,

Meu grande abraço. 


\section{RESUMO}

LOPES, M. R. F. Carne bovina reestruturada com óleo de canola e antioxidante: desenvolvimento e atributos sensoriais. [Restructured beef with canola oil and antioxidant: development and sensory attributes]. 2012. $100 \mathrm{f}$. Dissertação (Mestrado em Ciências) - Faculdade de Medicina e Veterinária e Zootecnia, Universidade de São Paulo, Pirassununga, 2012.

As indústrias do setor da carne têm buscado meios para agregar valor através da adição de ingredientes benéficos à saúde e pela utilização de cortes de baixo valor comercial. A produção de carnes reestruturadas e o uso de óleos vegetais em substituição a gordura animal são estratégicas tecnológicas, criando produtos mais adaptados as necessidades do consumidor em termos de conveniência, uniformidade, tamanho de porção, composição, fácil preparação e alimentação saudável. Portanto, objetivou-se avaliar as características quantitativas e qualitativas e a vida útil de bifes reestruturados desenvolvidos com músculo Triceps brachii (miolo da paleta), utilizando a enzima transglutaminase, antioxidante e adição de óleo de canola, de acordo com os tratamentos: (1) controle, (2) adição de $5 \%$ de óleo de canola, (3) adição de eritorbato de sódio e (4) adição de 5\% óleo de canola + eritorbato de sódio. A carne foi cortada e processada com $1 \%$ de $\mathrm{NaCl}$, $0,3 \%$ de tripolifosfato de sódio, $1 \%$ de enzima transglutaminase e $10 \%$ de gordura da carne. Ainda no misturador foram adicionados $5 \%$ de óleo de canola (2 e 4) e $0,05 \%$ de antioxidante ( 3 e 4). Os bifes foram embalados á vácuo individualmente e armazenados congelados a $-18^{\circ} \mathrm{C}$ por até 120 dias. Foram analisados: composição centesimal, $\mathrm{pH}$, perdas durante $\mathrm{o}$ descongelamento e cozimento, análise instrumental da cor, teor de colesterol, oxidação lipídica, textura e análise sensorial Os valores de $\mathrm{pH}$ foram maiores $(\mathrm{P}<0,05)$ aos 120 dias de armazenamento congelado, independente dos tratamentos. A adição de óleo de canola afetou $(P<0,05)$ a composição centesimal dos bifes, com exceção do teor de cinzas que não se alterou $(P>0,05)$. A maior perda de cozimento foi encontrada nos bifes reestruturados formulados com antioxidante mais óleo de canola $(23,66 \%)$, diferindo $(P<0,05)$ do bife reestruturado somente com antioxidante que apresentou a menor perda $(16,34 \%)$, porém não deferiram dos tratamentos controle e com óleo de canola. Não houve diferença $(P>0,05)$ para oxidação lipídica entre os tratamentos aos 0 e 30 dias de armazenamento, já aos 60, 90 e 120 dias, houve 
diferença $(P<0,05)$, onde os tratamentos sem adição de antioxidante tiveram os maiores resultados para TBARS. O tratamento com canola (2) também diferiu do tratamento controle (1) apresentando menores valores de TBARS aos 90 e 120 dias de armazenamento. A adição do óleo de canola e do antioxidante afetou $(P<0,05)$ o teor de colesterol na carne reestruturada crua, aumentou a luminosidade $\left(L^{*}\right)$ e intensidade do amarelo $\left(b^{*}\right)$, mas não influenciou a intensidade de vermelho $\left(\mathrm{a}^{*}\right)$. Os tratamentos com adição de óleo de canola apresentaram os menores valores de dureza. Os bifes reestruturados com adição de óleo de canola e eritorbato de sódio possuem propriedades físico-químicas e sensoriais aceitáveis, podendo ser comercializado como um produto de preparo rápido e possivelmente com maior valor agregado

Palavras-chave: Bife reestruturado. Eritorbato de sódio. Canola. Textura. Oxidação lipídica. 


\section{ABSTRACT}

LOPES, M. R. F. Restructured beef with canola oil and antioxidant: development and sensory attributes. [Carne bovina reestruturada com óleo de canola e antioxidante: desenvolvimento e atributos sensoriais]. 2012. $100 \mathrm{f}$. Dissertação (Mestrado em Ciências) - Faculdade de Medicina e Veterinária e Zootecnia, Universidade de São Paulo, Pirassununga, 2012.

The meat sector industries are looking for ways to add value by adding ingredients beneficial to health and by use the cuts of low commercial value. The restructured meat production and use vegetable oils in place of animal fat are strategic technology, creating products more adapted to the needs of the consumer in terms of convenience, uniformity, portion size, composition, easy preparation and healthy eating. Therefore, the objective was to evaluate the quantitative and qualitative characteristics and shelf life of the restructured beef developed with Triceps brachii, using the enzyme transglutaminase, antioxidant and addition of canola oil, according to the following treatments: (1) control, (2) added 5\% canola oil, (3) added of sodium erythorbate and (4) added of $5 \%$ canola oil + sodium erythorbate. The meat was cut and processed with $1 \% \mathrm{NaCl}, 0.3 \%$ sodium tripolyphosphate, $1 \%$ transglutaminase enzyme and $10 \%$ beef fat. Also in the mixer was added $5 \%$ canola oil (2 and 4 ) and $0.05 \%$ of antioxidant ( 3 and 4 ). The steaks were vacuum packaged individually and stored frozen at $-18^{\circ} \mathrm{C}$ up to 120 days. In the final product were analyzed: chemical composition, $\mathrm{pH}$, losses during thawing and cooking, instrumental analysis of color, cholesterol, lipid oxidation, texture and sensory analysis. The $\mathrm{pH}$ values were higher $(\mathrm{P}<0.05)$ at 120 days of frozen storage for all treatments. The addition of canola oil affected $(P<0.05)$ the chemical composition of restructured steaks, with the exception of ash content did not change $(P>0.05)$. The greatest loss of cooking has been found in restructured steaks formulated with antioxidant more canola oil $(23.66 \%)$ differing $(P<0.05)$ of the restructured steak with only antioxidant that showed the smallest loss (16.34\%), but not differed the control and canola oil treatments. There were no difference $(P>0.05)$ for lipid oxidation between treatments at 0 and 30 days of storage, but at 60,90 and 120 days, there were a difference $(P<0.05)$, where treatments without antioxidant addition had the greatest results for TBARS. Treatment with canola (2) also differed 
from the control treatment (1), exhibited lower TBARS values at 90 and 120 days of storage. The addition of canola oil and antioxidant affected $(P<0.05)$ cholesterol content in raw restructured beef increased the lightness $\left(L^{*}\right)$ and intensity of yellow $(b *)$, but did not influence the intensity of red $\left(a^{*}\right)$. The treatments with the addition of canola oil had the lowest hardness values. The steaks restructured with the addition of canola oil and sodium erythorbate have physicochemical and sensory properties acceptable and can be marketed as a product of rapid preparation and possibly with greater added value.

Keywords: Restructured steak. Sodium erythorbate. Canola. Texture. Lipid oxidation. 


\section{LISTA DE TABELAS}

Tabela 1 - Concentração de colesterol $(\mathrm{mg} / 100 \mathrm{~g})$ na carne bovina.

Tabela 2 - Formulação dos diferentes tratamentos de carne reestruturada bovina.

Tabela 3 - Médias das análises físico-químicas do músculo Triceps brachi. .55

Tabela 4 - Valor do pH entre os tratamentos nos diferentes tempos de armazenamento

Tabela 5 - Médias e erros-padrão dos resultados das análises físico-químicas da carne reestruturada crua.

Tabela 6 - Médias e erros-padrão dos resultados de perdas por cocção da carne reestruturada

Tabela 7 - Médias e erros-padrão dos resultados do valor TBARS (mg malonaldeído/ kg de amostra) da carne reestruturada.

Tabela 8 - Médias e erros-padrão dos resultados de teor de colesterol (mg/100g) da carne reestruturada

Tabela 9 - Resultados das análises microbiológicas da matéria-prima e carne reestruturada crua com 0 e 120 dias, em comparação aos limites da legislação

Tabela 10 - Médias e erros-padrão dos resultados do perfil colorimétrico instrumental da carne reestruturada de acordo com os tratamentos....68

Tabela 11 - Médias e erros-padrão dos resultados dos parâmetros de textura da carne reestruturada avaliada através de TPA.

Tabela 12 - Médias e erros-padrão dos resultados dos parâmetros de textura da carne reestruturada avaliada através da força de cisalhamento

Tabela 13 - Médias e erros-padrão dos resultados da avaliação sensorial da carne reestruturada para os atributos aroma, maciez e suculência

Tabela 14 - Médias e erros-padrão dos resultados da avaliação sensorial da carne reestruturada para o atributo de sabor. 


\section{LISTA DE FIGURAS}

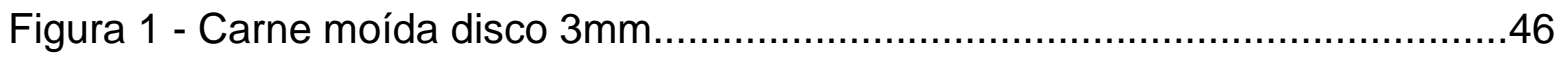

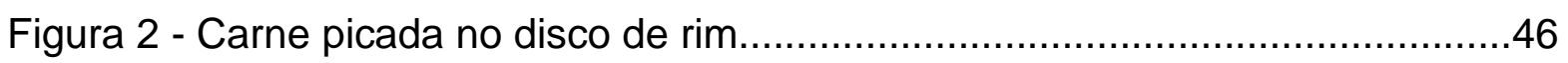

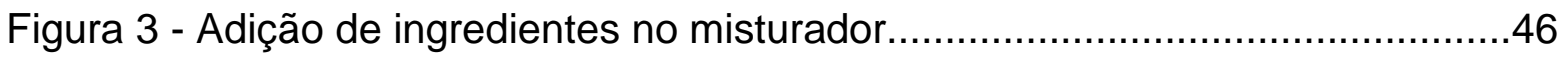

Figura 4 - Bife sendo grelhados em chapa elétrica.............................................49

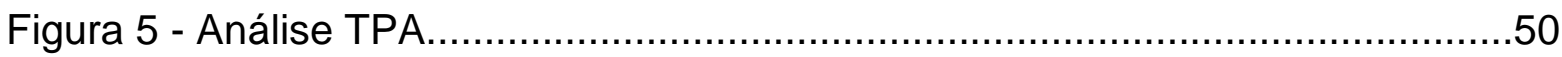

Figura 6 - Análise de cisalhamento com célula de corte plano..............................50

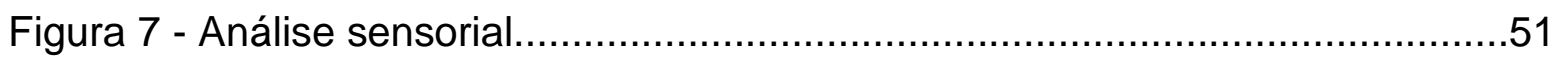

Figura 8 - Interação tratamento $x$ tempo de armazenamento no valor TBARS

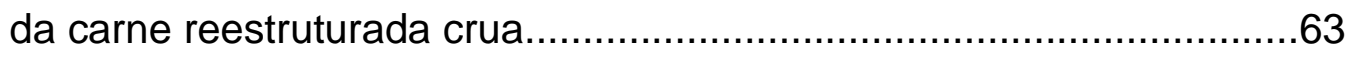

Figura 9 - Valores de $L^{*}$ do músculo Triceps brachii em função do tempo

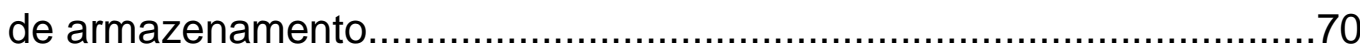

Figura 10 - Valores de b* do músculo Triceps brachii em função do tempo de armazenamento............................................................................. 70

Figura 11 - Distribuição da classe econômica dos consumidores que realizaram

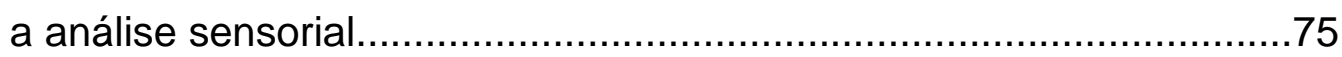




\section{SUMÁRIO}

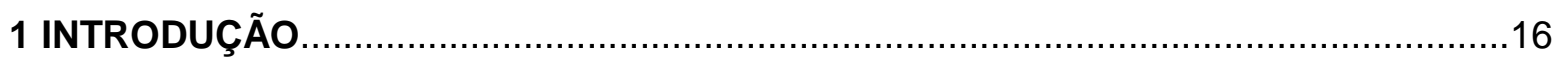

2 OBJETIVO

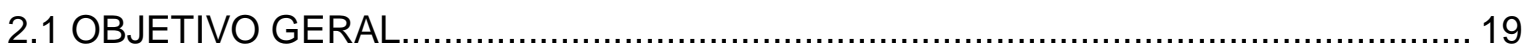

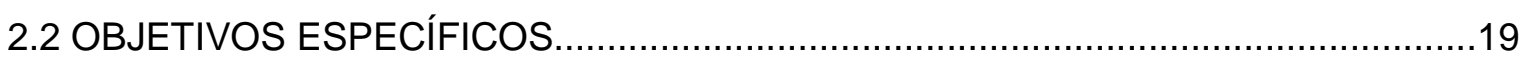

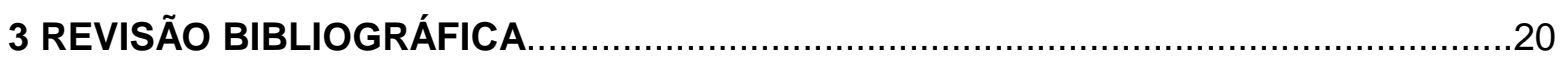

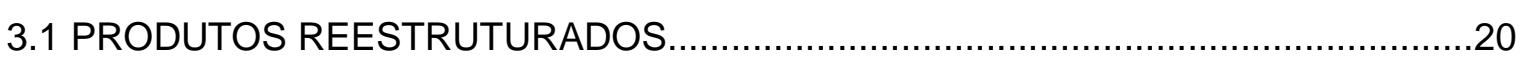

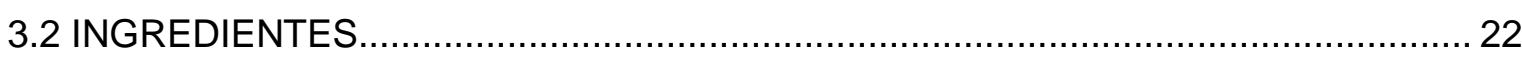

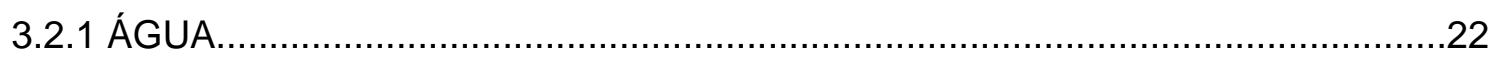

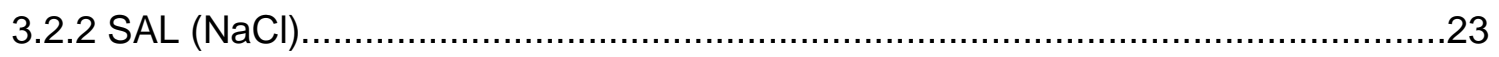

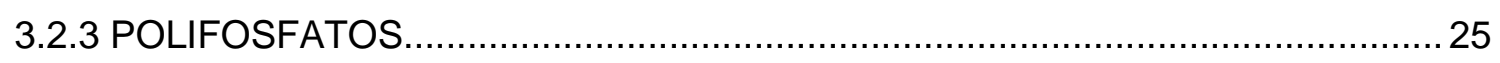

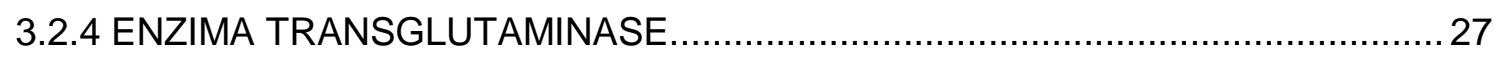

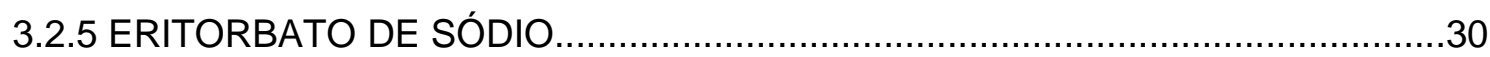

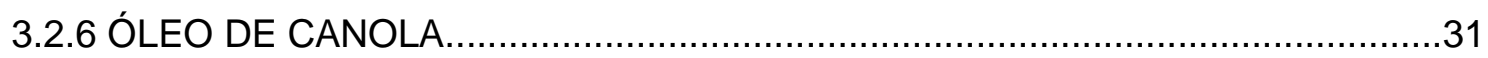

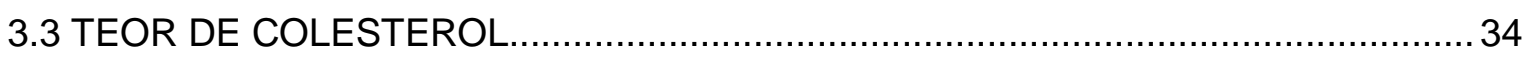

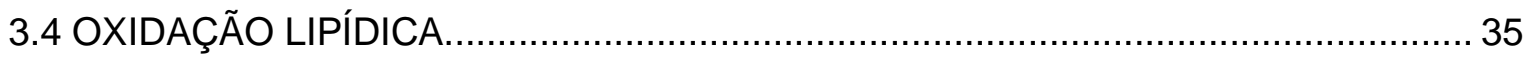

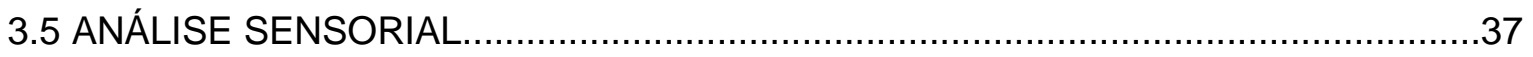

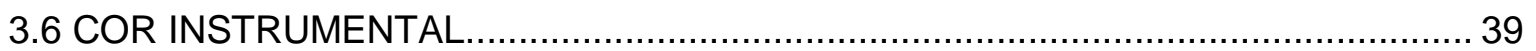

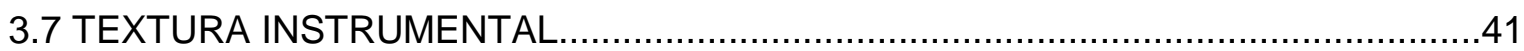

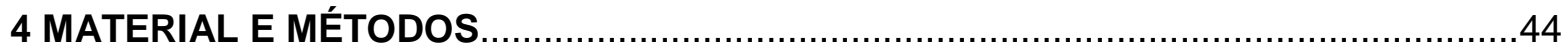

4.1 LOCAL E OBTENÇÃO DE MATÉRIA-PRIMA ........................................................... 44

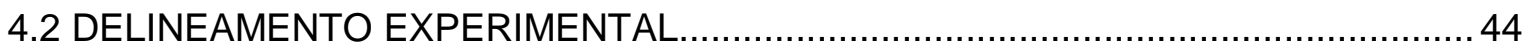

4.3 FORMULAÇÃO DA CARNE REESTRUTURADA E TRATAMENTOS ......................45

4.4 ANÁLISES FÍSICO-QUÍMICAS NA MATÉRIA-PRIMA E NA CARNE

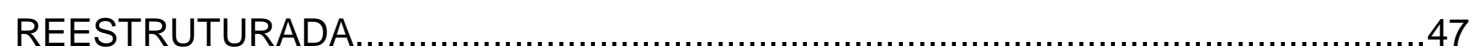

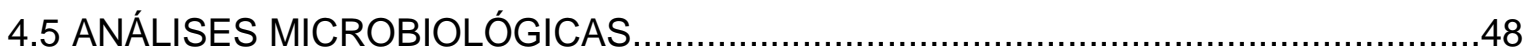

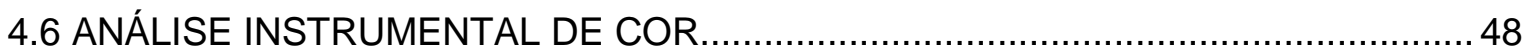

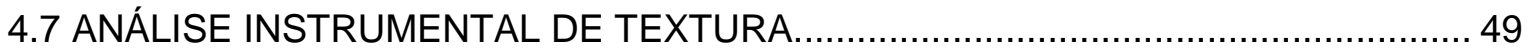

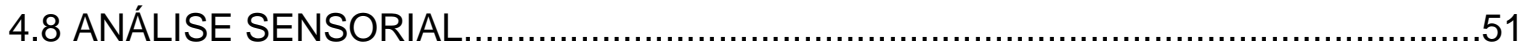

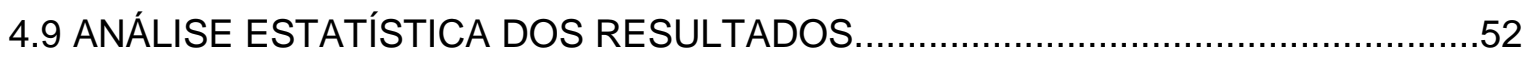

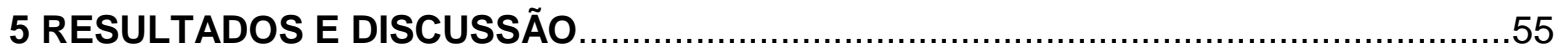

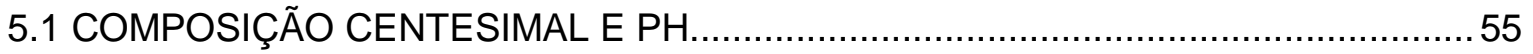




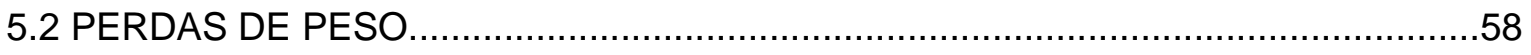

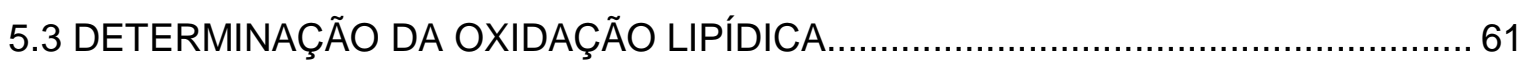

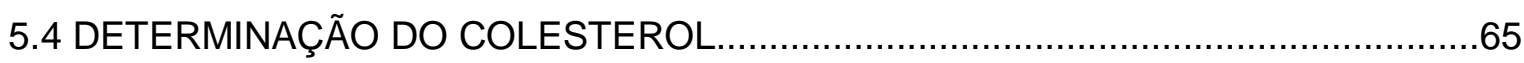

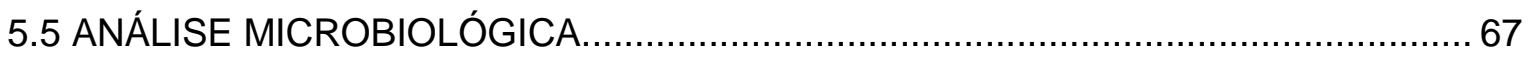

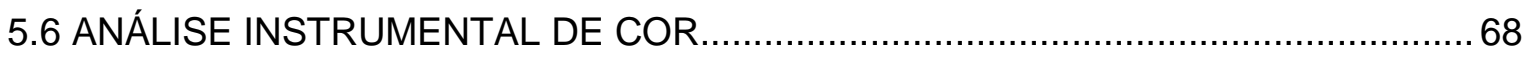

5.7 ANÁLISE INSTRUMENTAL DE TEXTURA................................................... 71

5.7.1 ANÁLISE DE PERFIL DE TEXTURA.................................................... 71

5.7.2 DETERMINAÇÃO DA FORÇA DE CISALHAMENTO ...................................74

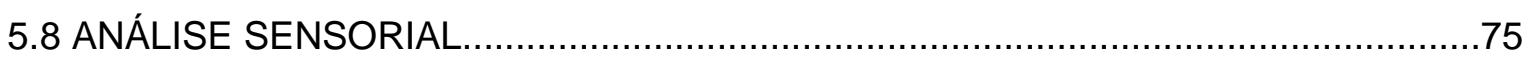

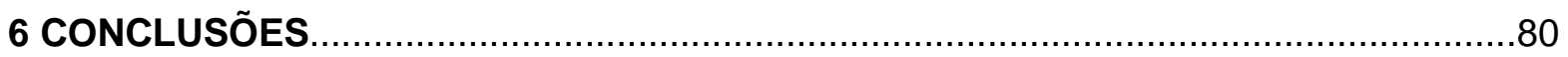

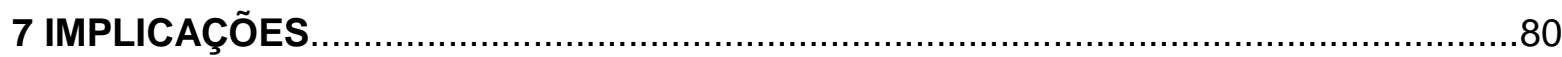

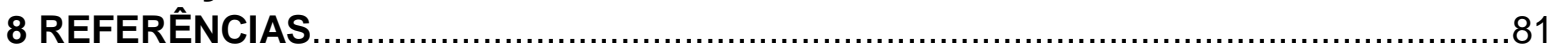




\section{INTRODUÇÃO}

A indústria de carnes está modificando rapidamente, em função das transformações tecnológicas e demanda por alimentos, além de outros fatores.

Aliado ao desafio atual da indústria em reduzir custos por meio do aproveitamento de cortes sem valor comercial, transformando-os em um produto de alto valor comercial e a tendência do mercado atual em desenvolver produtos para um consumidor que busca conveniência, as carnes reestruturadas foram desenvolvidas com o objetivo da criação de novos produtos que podem ser adaptados para as necessidades do consumidor em termos de conveniência, tamanho de porção, composição e fácil preparação, pela mudança dos ingredientes empregados na sua preparação (ESGUERRA, 1994). Além de oferecer vantagens para a indústria cárnea, uma vez que agregam valor pela utilização de peças de músculos íntegros de menor aceitação, criando produtos mais uniformes em relação à forma, cor e textura (FLORES; BOYLE; KASTNER, 2007), especialmente aos cortes do dianteiro bovino.

A indústria geralmente deseja produzir carnes reestruturadas que possam competir com músculos íntegros em relação às características sensoriais como aparência, odor, sabor e textura, importantes para sua aceitação. Em especial a textura dos reestruturados devem se assemelhar à dos cortes íntegros e para isto, a propriedade funcional mais importante é a de ligação entre os fragmentos da carne (SEIDEMAN, 1982).

A ligação entre os fragmentos cárneos é causada pela solubilização das proteínas na superfície destes, que são moldados por compressão na forma desejada e, em seguida, unidos em uma só peça (SMITH, 1982; WESTPHALEN; BRIGGS; LONERGAN, 2005).

Para que melhor ocorra à ligação entre os fragmentos cárneos diferentes sistemas ligantes vêm sendo estudados e dentre os produtos comerciais está à enzima transglutaminase (Activa TG-EB®). Lennon et al. (2006), utilizaram o ligante Activa TM e relataram que 0 ingrediente ativo é a enzima transglutaminase de cadeia cruzada no qual catalisa a polimerização e liga as proteínas da carne. A transglutaminase (MTGase) é uma enzima cálcio independente produzida por uma cepa não-toxigênica e não-patogênica do microrganismo Streptoverticillium 
mobaraense. Essa enzima catalisa reações acil-transferase entre grupos de resíduos de glutamina de proteínas e aminas primárias (acil-aceptores) incluindo o grupo e-amino de resíduos de lisina em certas proteínas, resultando na formação de ligações covalentes intermoleculares (MOTOKI; SEGURO, 1998), que por meio destas ligações a MTGase promove a adesão das partículas cárneas para obtenção de carne reestruturada.

Outra tendência da indústria de carne é a redução no uso de gordura animal em produtos cárneos, uma vez que estão sendo propostas relações entre o alto nível de colesterol, baixa proporção ácido graxo poliinsaturados /saturados (AGPI / AGS) e aumento de doenças cardíacas coronárias com uso de produtos alimentares com alto teor de gordura incluindo-se alguns produtos cárneos (GIESE, 1992). Portanto, trata-se do uso de estratégias que incluem o uso de óleos vegetais como um substituto para as gorduras animais, dando origem a produtos com um melhor perfil de ácidos graxo e menores níveis de colesterol, quando comparados aos tradicionais (TEYE et al., 2006; ÖZVURAL; VURAL, 2008).

Alguns óleos vegetais contêm grandes quantidades de ácidos graxos monoinsaturados (MUFA) e são todos livres de colesterol. MUFA e PUFA podem auxiliar na redução do plasma de lipoproteína de baixa densidade (LDL). Além disso, níveis mais elevados de PUFA podem aumentar a lipoproteína de alta densidade (HDL) e reduzir a incidência de doença cardíaca coronariana (MATTSON; GRUNDY, 1985; MOZAFFARIAN et al., 2005).

Além disso, Serrano, Cofrades, Jiménez-Colmenero (2004) utilizaram carne convencional, pelo sistema de reestruturação (incluindo $\mathrm{NaCl}$ e fosfato), com adição de óleo para produção de carne bovina reestruturada (pré-cozida e congelada) observaram que os produtos tiveram boa aceitabilidade físico-química e propriedades sensoriais.

Polifosfatos ou suas combinações são incorporadas em salsichas e produtos cárneos reestruturados para elevar suas qualidades em relação à capacidade de retenção de água (KNIPE; OLSON; RUST, 1985; ANJANEYULU; SHAMA; KONDAIAH, 1989; BERNTHAL; BOOREN; GRAY, 1991), ligação entre as partículas da carne (DOBSON et al., 1993; MOISEEV; CORNFORTH, 1997), estabilidade de emulsão (KNIPE; OLSON; RUST, 1985), rendimento de cocção (ANJANEYULU; SHAMA; KONDAIAH, 1989; MOISEEV; CORNFORTH, 1997), cor, sabor e textura (SMITH et al., 1973; YOUNG et al., 1987). 
Alguns pesquisadores afirmaram que a carne reestruturada pode apenas ser comercializada pré-cozida ou congelada, pois a estrutura do produto ligado não é muito consistente no estado cru. Produtos cárneos são freqüentemente armazenados em freezer com temperaturas para estender a estabilidade de prateleira por objetivos de compra e distribuição. O armazenamento destes produtos cárneos congelados pode causar mudanças químicas e estruturais, dependendo de suas características (matéria prima, quantidade e tipo de lipídios, antioxidante e uso de acondicionamento protetor) e condições de armazenamento (temperatura, duração e variações de temperatura). Cada mudança, no qual ocorre largamente como um resultado de alterações em suas características protéicas (agregação e desnaturação) e lipídicas (oxidação) produz efeitos indesejáveis sobre algumas características do produto, como textura, gordura, propriedades de ligação de água e cor, no qual reduz a qualidade e a vida de prateleira de produtos cárneos (AWAD; POWRIE; FENNEMA, 1968; MILLER; ACKERMAN; PALUMBO, 1980; BHATTACHARYA; HANNA; MANDIGO, 1988a, BHATTACHARYA; HANNA; MANDIGO, 1988b). 


\section{OBJETIVO}

\subsection{OBJETIVO GERAL}

Objetivou-se avaliar as características quantitativas e qualitativas e a vida útil de bifes reestruturados desenvolvidos com músculo Triceps brachii (miolo da paleta), enriquecido ou não com óleo de canola, com ou sem a utilização de antioxidante.

\subsection{OBJETIVOS ESPECÍFICOS}

$\checkmark \quad$ Elaborar, com a utilização do músculo Triceps brachii como matériaprima, carne bovina reestruturada, e avaliar as suas características sensoriais (aroma, textura, suculência e sabor) e físicas (cor, textura e composição centesimal);

$\checkmark \quad$ Estudar o efeito da adição de antioxidante industrial (eritorbato de sódio) e do óleo de canola na carne reestruturada sob a vida útil do produto armazenado congelado, por meio da análise de oxidação lipídica;

$\checkmark \quad$ Avaliar o efeito da adição de óleo de canola na carne reestruturada quanto às características sensoriais (aroma, textura, suculência, sabor e aceitação) e físico-químicas (cor, perfil de textura, teor de colesterol e composição centesimal). 


\section{REVISÃO BIBLIOGRÁFICA}

\subsection{PRODUTOS REESTRUTURADOS}

Com o processamento da carne busca-se a elaboração de novos produtos com a finalidade de prolongar a vida-de-prateleira, por atuar sobre enzimas e microrganismos de caráter degradativo, atribuindo-se características sensoriais como, cor, sabor e aroma, próprias de cada processo e não modificando significativamente a qualidade nutricional original (ROMANELLI; CASERIL; FILHO, 2002).

No Brasil, o interesse por produtos reestruturados vem crescendo com decorrer dos anos. A elaboração de produtos reestruturados é realizada pela desintegração do músculo através de processos mecânicos, nos quais os pedaços resultantes são misturados, para posteriormente serem formatados em porções específicas (KEETON, 2001).

Os métodos de redução de tamanho mais comumente utilizados são o de moagem fina ou grosseira e fatiamento. Penfield et al. (1992) estudaram o efeito do tamanho dos fragmentos em carne bovina reestruturada com a utilização de músculos do quarto dianteiro e relataram que o aumento da mastigabilidade está associado a produtos utilizando fragmentos maiores.

Entretanto, para obtenção de um produto mais homogêneo e com maior aceitabilidade, faz-se necessário que uma parte da carne seja moída grosseiramente e a outra de forma mais fina, resultando em um reestruturado com maior coesividade (HUFFMAN; CORDRAY, 1982; BERNAL et al., 1988). Esse mesmo processo de cominuição foi utilizado por Schaake et al. (1993).

O músculo é coberto por uma camada de tecido conectivo (epimísio), quando essa camada permanece intacta, pouca ou nenhuma extração de proteínas miofibrilares ocorre, por essa razão é necessário moer o músculo para ocorrer a redução das partículas e aumentar a área de contato para a extração protéica. Essa fase é fundamental no processamento, pois caso não ocorra a extração de proteínas, os pedaços não se ligarão, resultando em um produto com textura 
inconsistente. Após a moagem adiciona-se o sal e o tripolifosfato de sódio juntamente com a água para ocorrer à máxima extração protéica. A água pode ser adicionada na forma de gelo com o objetivo de abaixar a temperatura da carne (OWENS, 2001). Nos processos de moagem e mistura o controle da temperatura é essencial para a obtenção do produto final desejável e para se evitar problemas na coloração e oxidação (PEARSON; DUTSON, 1987). Conforme Mandigo (1982), temperaturas próximas ao ponto de congelamento $\left(-4^{\circ} \mathrm{C}\right)$ auxiliam na solubilização das proteínas miofibrilares (ótima solubilização da miosina), melhoram a eficiência no processo de redução das partículas, tornam o processo de mistura mais efetivo, protegem o sabor e aumentam a vida útil dos produtos. No entanto, a principal função é o controle da formação de coloração indesejável no produto, pois quanto menor a temperatura menor a probabilidade de formação de metamioglobina, responsável pelo escurecimento da carne.

O tempo de mistura também é de suma importância para a qualidade do produto final e está relacionado principalmente à textura e capacidade de ligação, mas também ao resíduo de tecido conjuntivo, rendimento de cozimento, suculência, sabor e maciez. Segundo Owens (2001), se durante o processamento do reestruturado, a carne for extremamente moída e a massa homogeneizada em excesso ocorrerá a desnaturação protéica resultando em um produto com pouca ligação com a água.

De acordo com Mandigo (1982), as duas maiores funções do processo de mistura são: (1) introdução e homogeneização dos ingredientes com a matériaprima, e (2) solubilização das proteínas miofibrilares através da ação mecânica o que é acelerado com o uso de sal. Essas proteínas extraídas auxiliam na ligação do produto (MANDIGO, 1982; TÉLLEZ-LUIS et al., 2002).

Segundo Ghavimi, Althen e Rogers (1987), a habilidade de ligação é o fator mais importante para carne reestruturada, devido à necessidade de manter a integridade estrutural durante os processos de manipulação e distribuição até que chegue à mesa do consumidor e durante o cozimento. 


\subsection{INGREDIENTES}

A crescente demanda do consumidor por produtos naturais e saudáveis tem contribuído para aumentar o interesse pelo estudo dos ingredientes utilizados na fabricação de alimentos. É possível utilizar diversos ingredientes que melhorem as propriedades funcionais das proteínas naturais da carne, aumentando a sua capacidade de retenção de água e formação de gel, resultando em produtos com melhor suculência, estrutura e textura similar ao músculo íntegro (PEARSON; GILLETT, 1996; BARBUT, 2002).

\subsection{1 ÁGUA}

A água é um importante componente dos reestruturados, o teor de umidade varia em função da quantidade de água adicionada durante o preparo e da porção carne magra/gordura presente no reestruturado. Nos diversos estudos com carne bovina reestruturada realizados por Lee, Hendricks e Cornforth (1998), Serrano et al. (2007), Serrano, Cofrades e Jiménez-Colmenero (2004), Lennon et al. (2006), Colmenero et al. (2003), Reverte, Xiong e Moody (2003) o teor de água utilizado foi entre 8 a 15\% em relação ao total do produto.

A água tem a função de solubilizar as proteínas hidrossolúveis e atuar como constituinte de uma salmoura necessária para a solubilização das proteínas miofribilares. Nas fibras musculares estão localizadas as proteínas miofibrilares, actina e miosina, que são solúveis em meio com água contendo sal, o qual permite atingir-se a força iônica necessária para a sua solubilização. Durante o processo de cominuição, as proteínas são liberadas formando um gel. Este gel formado condiciona a capacidade de ligar água e emulsificar gordura na massa. As proteínas sarcoplasmáticas solubilizam-se em água, sem necessidade de adição de sal e permanecem solubilizadas mesmo após a adição deste. As proteínas que são importantes para a ligação de água e gordura são solúveis ao sal. A fim de se obter a solubilização das proteínas, ou promover-se sua hidratação, é necessária a 
adição de água, além do sal. A quantidade de água adicionada definirá a capacidade de liga das proteínas ou sua capacidade emulsificante (LEMOS, 2002).

A água influencia a palatabilidade dos produtos cárneos, contribuindo para sua textura e suculência do produto final.

A relação umidade:proteína deve ser otimizada para cada produto, porque o excesso de água, além de prejudicar a textura pode resultar em um produto de pouca consistência e a falta de água, além de prejudicar a textura, pode elevar os custos do produto.

Uma consideração importante a respeito da água usada no processamento de carnes é que a mesma deve ser tanto quanto possível livre de contaminantes químicos e microbiológicos, e de minerais. Estes atuam como pró-oxidantes (cobre e ferro) e dificultam a dissolução de outros ingredientes da salmoura (LEMOS, 2002).

3.2.2 SAL $(\mathrm{NaCl})$

O cloreto de sódio é o único sal que, dissolvido na água, provoca um sabor salgado puro nos receptores gustativos da língua. O sal $(\mathrm{NaCl})$ tem sido empregado extensivamente pelas indústrias alimentícias, visando melhorar as propriedades funcionais por meio do aumento da absorção de água e da solubilidade protéica, além de contribuir para o sabor dos alimentos (VAN-HEKKEN; STRANGE, 1993).

Em relação às propriedades tecnológicas propriamente ditas, o sal influi sobre a capacidade de retenção de água das proteínas cárneas, especialmente as miofibrilares. Vale acrescentar que os íons cloreto e não o sódio é o principal responsável pela capacidade habilidade do sal de ligar-se a água. Com a adição de sal, aumenta-se a força iônica do meio, permitindo que as proteínas miofibrilares absorvam a água e solubilizem-se. A solubilidade destas proteínas aumenta até uma concentração de sal de cerca de $6 \%$, portanto, quando o teor de sal adicionado é superior a este limite, ocorre a precipitação das proteínas, ocasionando perda da capacidade de retenção de água (LEMOS, 2002).

Segundo Cheftel et al. (1989), a natureza e a concentração de íons exercem efeitos sobre a absorção de água e a solubilidade das proteínas. Assim, 
concentrações salinas compreendidas entre 0,5 e 1M (para os sais neutros), podem elevar a solubilidade da proteína (efeito "salting in") devido ao aumento da solvatação. Essa ação benéfica do sal tem sido aproveitada pelas indústrias alimentícias, que utilizam $\circ \mathrm{NaCl}$ como ingrediente nos alimentos, visando aumentar a solubilidade e a estabilidade, melhorando, assim as propriedades emulsificantes de vários produtos (VAN-HEKKEN; STRANGE, 1993). Por outro lado, quando os níveis de sais são mais elevados, predominam as interações águasal, em detrimento das interações água-proteína (efeito "salting out"), contribuindo para reduzir a solubilidade protéica (CHEFTEL et al., 1989).

O sal atua, ainda, como substância conservante nos produtos cárneos. $O$ efeito conservante do sal é devido ao abaixamento da atividade da água do produto, retardando o crescimento microbiano, ou seja, seu efeito é bacteriostático e não bactericida (LEMOS, 2002).

Téllez-Luis et al. (2002) testaram diferentes formulações em carne reestruturada utilizando apenas MTGase e verificaram que produtos reestruturados apresentam pobre coesividade e aumento no exsudado. No entanto, quando se associou MTGase e $\mathrm{NaCl}$ houve melhoria na aparência em relação às mesmas características,comprovando que o sal é necessário para induzir a interação entre água e proteína durante a elaboração desses produtos.

Em pesquisa realizada por Baublits et al. (2006), os músculos Biceps femoris, Infraspinatus e Longissimus foram injetados com tripolifosfato de sódio e diferentes níveis de sal. Os autores observaram redução das perdas no cozimento,com o aumento do nível de sal, devido a ao aumento de forças iônicas e seu impacto na capacidade de retenção de água. A maciez instrumental e sensorial foi significativamente melhorada assim como a quantidade de tecido conjuntivo detectável diminuiu quando formulados com teor de $1 \%$ de $\mathrm{NaCl}$.

De acordo com os dados de Dimitrakopoulou et al. (2005), o aumento no nível de sal adicionado em um reestruturado suíno aumentou o conteúdo de umidade, porém exerceu um efeito negativo sob a cor do produto, devido a sua ação pró-oxidante diante da mioglobina. 


\subsubsection{POLIFOSFATOS}

Os fosfatos são os estabilizantes mais utilizados em produtos cárneos e na maioria das vezes são obtidos de forma sintética. O ácido ortofosfórico, do qual é derivado o ácido metafosfórico e o ácido pirofosfórico, obtido a partir da condensação de duas moléculas de ácido ortofosfórico, são bastante conhecidos. A condensação de várias moléculas do ácido ortofosfórico dá origem aos ácidos polifosfóricos de cadeia linear e a condensação do ácido metafosfórico origina os ácidos polifosfóricos de cadeia cíclica. Pode-se considerar que a fórmula geral dos ácidos polifosfóricos $[\mathrm{H}(\mathrm{n}+2) \mathrm{PnO}(3 n+1)$ e $(\mathrm{HPO}) \mathrm{n}]$ dos dois tipos, tende a aproximar-se quando "n" aumenta (SHIMP, 1983).

Os fosfatos utilizados no processamento de carnes são sais destes ácidos, que podem ser alcalinos ou ácidos. Dentre os sais alcalinos destacam-se os seguintes: pirofosfato dissódico, pirofosfato tetrassódico, tripolifosfato pentassódico, pentapolifosfato de sódio, hexametafosfato de sódio e os sais de potássio correspondentes (SHIMP, 1983).

Os polifosfatos alcalinos são amplamente utilizados pela indústria frigorífica. A ação destes em melhorar a capacidade de retenção de água na carne é significativa, pois o uso destas substâncias ajusta o $\mathrm{pH}$ do sistema e favorece a expansão das fibras da proteína da carne, permitindo a hidratação da mesma. A água é mantida associada às proteínas miofibrilares, nos sítios hidrofílicos da proteína. Estudos demonstram que o uso do fosfato gera melhorias na textura, suculência e no rendimento dos produtos marinados devido à boa retenção de salmoura. Apenas os fosfatos alcalinos são eficazes para melhorar a retenção de água, pois os fosfatos ácidos podem abaixar o $\mathrm{pH}$ e causar encolhimento maior (OLIVO, 2006).

As carnes geralmente apresentam pH entre 5,4 e 5,8 e o ponto isoéletrico das proteínas situa-se entre 5,1 a 5,2, correspondendo ao $\mathrm{pH}$ onde a capacidade de retenção de água é mínima. As misturas comerciais de polifosfatos utilizadas apresentam pH (em solução aquosa a 1\%) inferior a 9, mas próximo deste valor. Os polifosfatos componentes destas misturas apresentam em solução aquosa $1 \% \mathrm{pH}$ variando de 8,3 a 10,4, com exceção do hexametafosfato, que é utilizado em 
pequenas quantidades, cujo $\mathrm{pH}$ é 6,4, e o pirofosfato ácido com $\mathrm{pH}$ igual a 4,2 (BENDALL, 1972).

Desta forma, a adição de polifosfatos alcalinos, eleva o pH da carne de 0,2 a 0,5 unidades, tendo em vista a quantidade utilizada $(<0,5 \%)$ e o poder tamponante da carne, o que aumenta a capacidade de retenção de água com o deslocamento do $\mathrm{pH}$ do ponto isoelétrico (BENDALL, 1972).

O uso de fosfato de sódio em produtos cárneos tanto de bovino quanto de suíno ou ave aumentou devido ao seu efeito positivo em melhorar funcionalidade, estabilidade durante a estocagem e características sensoriais (MOISEEV; CORNFORTH, 1997).

Polifosfatos são incorporados em reestruturados devido as suas propriedades funcionais por melhorarem a capacidade de retenção de água (CRA), ligação entre os fragmentos da carne, cor, sabor, textura, retardam a rancidez oxidativa e reduzirem as perdas durante o cozimento e conseqüente aumento de rendimento (MOISEEV; CORNFORTH, 1997; LEE; HENDRICK; CORNFORTH, 1998).

Em relação à estabilidade da cor, os fosfatos podem quelar metais de transição formando complexos relativamente solúveis e estáveis podendo assim inibir a peroxidação lipídica em carne crua ou cozida. A atividade quelante pode contribuir para a estabilidade da cor em carne reestruturada devido a oxidação da mioglobina que é acelerada na presença de radicais livres ou baixo pH (GRAY; GOMAA; BUCKLEY, 1996; RASHCHI; FINCH, 2000).

O tripolifosfato de sódio (STPP) é a forma mais popular de fosfatos utilizado na indústria da carne, e é considerado mais efetivo quanto à ligação em carne reestruturada (TROUT; SCHMIDT, 1984). O STPP tem alto poder de penetração e dissolução quando comparado com outros fosfatos (XIONG, 2005). Os tripolifosfatos são usados mais comumente devido sua elevada solubilidade, mas se hidrolisam a pirofosfato na carne, sendo, portanto, o agente realmente efetivo (SOFOS, 1986).

Cipolli (2004) avaliou o efeito da injeção de salmouras contendo tripolifosfato e sal em músculos Tríceps brachii provenientes de carcaças estimuladas eletricamente e desossadas a quente e verificou-se cerca de $25 \%$ de aumento na maciez. A estimulação elétrica, assim como a forma de desossa promoveram efeitos secundários sobre a alteração das características física, sensorial e química 
do músculo Tríceps brachii, quando comparados com a marinação com salmoura contendo polifosfatos.

A adição de 0,4\% de STPP mostrou ser superior para a característica de cor comparado a adição de 0,2\%, e o STPP apresentou ter melhor desempenho em relação à cor quando o bife é exposto em displays de supermercados (BAUBLITS et al., 2005).

\subsubsection{ENZIMA TRANSGLUTAMINASE}

A transglutaminase é uma enzima capaz de melhorar as características funcionais das proteínas, pois catalisa as ligações covalentes entre a lisina e a glutamina, promovendo a adesão de partículas de carne sem necessidade de extração das proteínas miofibrilares. A actina e miosina, dentre muitas outras proteínas, são substratos específicos para esta enzima. Portanto, pode ser utilizada em produtos cárneos, especificamente para produzir reestruturado devido a sua habilidade em ligar os fragmentos cárneos em temperaturas abaixo de $10^{\circ} \mathrm{C}$ (MOTOKI; KUMAZAWA, 2000).

Contudo, esta enzima possibilita a formação de cubos de carne em uma sólida massa muscular, semelhante a um filé, por meio das ligações cruzadas entre as proteínas da carne, que consequentemente, influencia na textura do produto. Por essas razões, o uso de transglutaminase (TGase) é proposto a fim de melhorar as propriedades reológicas de alimentos, podendo ser amplamente utilizada em combinação com proteínas do leite, da soja e do ovo, carne bovina, suína, aves e pescado (PIETRASIK, 2003).

Recentemente, a transglutaminase microbiana (MTGase) adquiriu importância devido às inúmeras aplicações possíveis em alimentos, tornando importante buscar o aumento da disponibilidade e redução de custos de produção. De acordo com estudos baseados na seleção de milhares de microrganismos, linhagens do gênero Streptoverticillium têm a habilidade de produzir a transglutaminase em grandes quantidades devido ao tipo de crescimento micelial no meio de cultura, que é característico do gênero (YAN et al., 2005). Entretanto, sua principal vantagem sobre todas as outras fontes da enzima é de produzir uma 
enzima cálcio independente, e de peso molecular relativamente baixo. Estas características são importantes para a aplicação industrial da enzima (YOKOYAMA; $\mathrm{NIO}$; KIKUCHI, 2004).

Diversos estudos demonstram que a TGase produzida por microrganismos forma ligações cruzadas com a maioria das proteínas dos alimentos, tais como, caseínas, globulinas de soja, glúten, actina, miosina e proteínas dos ovos de forma tão eficiente quanto as TGase de mamíferos (YOKOYAMA; NIO; KIKUCHI, 2004).

Observou-se pH ótimo para a atividade da MTGase entre 5 e 8 . Entretanto, a enzima apresentou alguma atividade em uma faixa de $\mathrm{pH}$ de 4 a 9, podendo ser utilizada em vários processos alimentícios e em uma variedade de produtos como reestruturados, salsichas, produtos injetados, queijos, congelados e sobremesas. A temperatura ótima para atividade enzimática foi de $55^{\circ} \mathrm{C}$ (por $10 \mathrm{~min}$ a $\mathrm{pH} 6,0$ ); ela manteve toda sua atividade quando mantida por 10 min a $40^{\circ} \mathrm{C}$, porém perdeu atividade em apenas alguns minutos a $70^{\circ} \mathrm{C}$. A enzima ainda estava ativa a $10^{\circ} \mathrm{C}$, e manteve atividade residual até perto da temperatura de congelamento. No que diz respeito à especificidade quanto ao substrato, a maioria dos alimentos ricos em proteínas apresentam ligações cruzadas em seus grupos protéicos. Alimentos como globulinas de legumes, glúten de trigo, gema de ovo e albuminas, actinas, miosinas, fibrinas, caseínas de leite, alfa-lactoalbuminas e betalactoglobulina, assim como muitas outras albuminas foram testadas e foram substrato para ligações cruzadas feitas pela MTGase (KANG, et al., 1994; NONAKA et al., 1992, 1997; SEGURO et al., 1995).

A enzima transglutaminase forma ligação de isopeptídeos entre glutamina e resíduos de lisina em proteínas, introduzindo assim ligações covalentes cruzadas intra e intermoleculares. A reação mais importante desta enzima é a ligação cruzada entre proteínas que resulta na formação de e-(g-Glutamil) lisina (KURAISHI; YAMAZAKI; SUSA, 2001). Porém duas outras reações importantes podem ser catalisadas pela transglutaminase: (1) na presença de aminas primárias essa enzima pode atuar nas ligações cruzadas entre grupos amina e glutamina de proteínas (reação acil-transferase) e (2) na ausência de resíduos de lisina ou outras aminas primárias, a água reagirá como nucleófilo, resultando na deaminação de glutaminas. Todas essas reações podem modificar as propriedades funcionais das proteínas cárneas (MOTOKI; SEGURO, 1998; MOTOKI; KUMAZAWA, 2000; OHTSUKA et al., 2001; GERRARD, 2002). 
O uso da transglutaminase pode ser realizado em forma de pó, aplicado diretamente na superfície dos pedaços de músculo, por incorporação nos líquidos de marinação $(0,65$ - 1,5\%) ou por salmouras injetáveis e adição direta $(0,1$ - 0,3\%) em emulsionados tipo salsichas. De acordo com Dimitrakopoulou et al. (2005), a enzima adicionada em carne reestruturada não afeta as perdas no cozimento.

A transglutaminase pode utilizada a fim de melhorar ou modificar as propriedades reológicas e funcionais das proteínas. A polimerização da actomiosina pela transglutaminase é um método viável para reestruturação sem que sejam necessários os métodos de congelamento e/ou cozimento para manter a integridade do produto. O processo de ligação tem início 30 minutos após a aplicação e continua por algumas horas em temperaturas de refrigeração. Dessa maneira, a transglutaminase pode ser aplicada em vários produtos e também pode ser usada combinada a outros ingredientes como sal, fosfatos alcalinos e sais de cura (KEETON, 2001).

O uso de transglutaminase em carne reestruturada forma, após a indução térmica, uma fina rede, devido a mudanças na ultra microestrutura do gel, melhorando as propriedades físicas do produto, como firmeza, elasticidade, coesividade e textura em geral, sendo o controle da quantidade de enzima adicionada, do tempo de reação e da temperatura de fundamental importância para obter a textura desejável (KURAISHI; YAMAZAKI; SUSA, 2001).

Kutemeyer et al. (2005) concluíram que a adição de íons monovalentes (como $\mathrm{NaCl}$ ) aumenta a atividade da enzima e a estabilidade térmica da transglutaminase. Os resultados confirmam o efeito sinergístico do sal sobre a enzima, sendo que os maiores valores de atividade foram medidas quando o sal foi dissolvido na água.

Camargo (1999) analisou diferentes teores de transglutaminase combinados com diferentes teores de sal (0\% TGase e 3,61\% NaCl; 0,75\% MTGase e 2,86\% $\mathrm{NaCl}$ e 1,5\% TGase e 2,11\% $\mathrm{NaCl}$ ) e 1,3\% de tripolifosfato em carne reestruturada de peru. Em relação à força do gel, os resultados indicaram que o nível de 1,5\% de MTGase apresentou força relativamente menor que quando utilizado $0,75 \%$ da enzima. Isto pode ter ocorrido tanto pela falta de substrato quanto pelo fato de a enzima ser substituída pelo sal, e a diminuição deste no meio reduz a atividade enzimática, concluindo seu efeito sinérgico com o sal. Desta forma, o sal e o tripolifosfato agregam valor funcional à atividade enzimática da transglutaminase. 


\subsubsection{ERITORBATO DE SÓDIO}

A produção de radicais livres é controlada nos seres vivos por diversos compostos antioxidantes, os quais podem ter origem endógena ou serem provenientes da dieta alimentar e outras fontes. Os antioxidantes estabilizam ou desativam os radicais livres antes que ataquem os alvos biológicos nas células (ATOUl et al., 2005; BARREIROS et al., 2006).

De forma geral, denominam-se antioxidantes as substâncias, que presentes em concentrações baixas, comparadas ao substrato oxidável, retardam significativamente ou inibem a oxidação do substrato. Os radicais formados a partir de antioxidantes não são reativos para propagar a reação em cadeia, sendo neutralizados por reação com outro radical, formando produtos estáveis ou podem ser reciclados por outro antioxidante (ATOUI et al., 2005; OMONI; ALUKO, 2005; BARREIROS et al., 2006).

Dentre os antioxidantes, o eritorbato de sódio é o sal sódico do ácido eritórbico ou ácido isoascórbico, que é um isômero do ácido ascórbico. O eritorbato de sódio é utilizado em produtos cárneos com as funções principais de agir como seqüestrador de oxigênio, mudar o potencial redox do sistema e/ou reduzir a oxidação indesejável dos produtos (TOMPKIN; CHISTIANSEN; SHAPARIS, 1978).

O eritorbato de sódio é um sal sódico do ácido eritórbico ou ácido isoascórbico, que é um isômero do ácido ascórbico, são produtos sintéticos, sem ação de vitamina C. O eritorbato e o ascorbato de sódio são utilizados em produtos cárneos com as funções principais de agir como seqüestrador de oxigênio, mudar o potencial redox do sistema e assim, acelerar a formação da cor e estabilizar a cor característica de carnes curadas com nitrito (COUNSELL; HORNIG, 1981). Além da reação com o nitrito, o eritorbato por si só apresenta um forte efeito antioxidante, prevenindo o desenvolvimento de rancidez oxidativa, quando aplicado em concentrações acima de 100 ppm, sendo que em concentrações mais baixas pode acelerar o desenvolvimento da rancidez oxidativa (GRAY; PEARSON, 1987). Gray e Pearson (1987) demonstraram que a atividade redutora em carnes cruas apresenta uma função importante na prevenção da oxidação, sendo que a adição de substâncias que proviam elétrons para a metamioglobina mantinham a carne no estado reduzido, efetivamente retardando a oxidação. Segundo estes autores, em 
níveis elevados, os ascorbatos atuariam criando condições redutoras, enquanto que em baixos níveis eles seriam rapidamente exauridos, não conseguindo manter as condições redutoras e acelerando a oxidação.

Trindade et al. (2008) testaram a estabilidade físico-química e microbiológica da carne mecanicamente separada (CMS) de diferentes origens e estocada durante 99 dias a $-18^{\circ} \mathrm{C}$, com prévia mistura de conservante (nitrito de sódio) e antioxidante (eritorbato de sódio) e os resultados encontrados demonstraram que a adição de nitrito isoladamente não impediu a oxidação lipídica, avaliada pelo índice de TBARS e nem a alteração na cor. Por outro lado, observou-se que a adição de nitrito juntamente com eritorbato foi efetiva na redução dos problemas de oxidação lipídica na CMS, na preservação da cor vermelha desejável ( $\left.\mathrm{a}^{*}\right)$ ao longo do tempo e na estabilidade microbiológica de microrganismos mesófilos e psicrotróficos.

\subsection{6 ÓLEO DE CANOLA}

Óleos e gorduras desempenham papéis funcionais e sensoriais vitais em vários produtos alimentares. As gorduras interagem com outros ingredientes a fim de melhorar a textura, o sabor e auxiliar na sensação geral de lubrificação dos alimentos (GIESE, 1996).

A crescente ênfase em assuntos relacionados à saúde levou a indústria alimentícia, principalmente nos últimos anos a esforçar-se para desenvolver novos alimentos com melhores propriedades funcionais, palatabilidade e valor nutricional. Atualmente, a indústria da carne tem utilizado ingredientes nutracêuticos, reduzindo o uso de gorduras animais em substituição por óleos vegetais para atingir esse objetivo. A adição de óleos vegetais (por exemplo, óleo de canola e azeites) e fibra dietética (por exemplo, a partir de farelo de arroz e nozes) em produtos de carne é desejável, não só por suas propriedades nutricionais e benefícios à saúde (ÁLVAREZ et al., 2011), mas também para a sua melhoria tecnológica relacionada com a textura e propriedades de gelificação de proteínas (FERNÁNDEZ-GINÉS et al., 2005).

O nome canola provém da sigla em inglês Canadian Oil Low Acid, que significa "óleo canadense com baixo teor ácido". O ácido em questão é o erúcico, 
cujo conteúdo é inferior a $2 \%$ no óleo, nível saudável, de acordo com estudos do Canadá - um dos países que mais produz, consome e exporta óleo de canola (BELL, 1993). Segundo Muhammad et al. (1991) o ácido erúcico e glucosinolatos presentes no óleo de canola possuem sabor amargo.

A canola é uma cultura alternativa de inverno que se adequa bem às nossas condições climáticas, foi desenvolvida a partir do melhoramento da colza (Brassica campestris e Brassica napus) constituindo-se em fonte protéica promissora (GALDIOLI et al., 2002). A canola detém atualmente a terceira posição entre as culturas oleaginosas e consiste em uma importante fonte de óleo vegetal (ASHRAF; MCNEILLY, 2004).

No agronegócio mundial, a canola tem grande importância, mas ainda é muito pouco cultivada no Brasil. O maior produtor mundial de canola é a China, seguida da União Européia e do Canadá, sendo que a produção global chega a 25 milhões toneladas. No Brasil, o cultivo da canola em 2004, chegou a 15 mil hectares, com uma produção estimada em 18 mil toneladas. O Rio Grande do Sul é o maior produtor da oleaginosa, concentrando $74 \%$ da produção nacional (TOMM, 2004).

A canola (Brassica napus L. e Brassica rapa L.) pertence à família das crucíferas, gênero brássica. Os grãos possuem em torno de $38 \%$ de óleo, reconhecido como excelente fonte de ácido linolênico (ROWGHANI et al., 2007), além de possuir os mais baixos níveis de ácidos graxos saturados de quaisquer outros óleos vegetais convencionais (GIESE, 1996). Em virtude dessas suas qualidades, o óleo de canola tem conquistado espaço no mercado ano após ano e inclusive tem sido comercializado a preços mais altos (D'OLIVEIRA, 1997), apresentando um aumento na demanda de consumidores preocupados com a dieta (GROMBACHER; NELSON, 1992). Segundo Furuya et al. (1997), o óleo de canola apresenta aproximadamente 58\% de ácido oléico (C18:1), 22\% de ácido linoléico (C18:2) e 10\% de ácido linolênico (C18:3); seu teor de ácidos graxos poliinsaturados é maior que o dos óleos de amendoim e dendê e menor que o dos óleos de soja, girassol, milho e algodão.

O emprego de óleo de canola na alimentação humana proporciona efeitos benéficos na composição lipídica do sangue, com aumento significativo de ácido $\alpha$ linolênico e EPA no plasma, assim como aumento nos teores de EPA e DHA nas plaquetas (CORNER et al., 1990). O óleo de canola também pode ser convertido 
para o altamente insaturado ácido graxo ómega-3 eicosapentaenóico (EPA) e ácido docosahexaenóico (DHA) no corpo (GUSTAFSSON et al., 1994), é uma boa fonte de antioxidante tocoferol (NYDAHL et al., 1995), possuí efeito hipocolesterolêmico (NYDAHL et al., 1995) e efeito antitrombótico (KWON et al., 1991). Awad e Fink (2000) relataram que o fitoesterol no óleo de canola oferece proteção contra cólon, de mama e câncer de próstata.

Outra vantagem importante da canola é a presença de ácidos fenólicos e seus derivados, bem como taninos condensados na sua composição (KRYGIER et al 1982;. NACZK et al. 1994). Naczk et al. (2000) relataram que a casca da canola e da colza contêm até $6 \%$ de taninos condensados. De acordo com Hagerman et al. (1998) o tanino deve ser considerado um antioxidante biológico importante. Portanto, a utilização destas oleaginosas, como uma fonte de antioxidantes naturais podem fornecer um meio para a sua utilização.

Nardin, Graner e Verruma-Bernardi (1999), utilizaram 12,5\% de óleo de canola na elaboração de fiambre de frango e observaram por meio da avaliação sensorial uma tendência, quanto à aceitabilidade, de produtos elaborados com óleos de milho e de canola. Os autores também observaram que a utilização de óleo de canola aumenta o rendimento do produto após o tratamento térmico.

Resende et al. (2010) ao desenvolver patê de tilápia com adição de 18,5\% de óleo de canola, relataram um aumento no teor de extrato etéreo. Porém, o teor de colesterol foi reduzido $(38,68 \mathrm{mg} / 100 \mathrm{~g})$. Também foi observado elevado teor de ácido graxo linolênico (18:3w3) e DHA em decorrência do uso do óleo de canola na formulação, elevando também o somatório dos ácidos graxos da série $\omega 3$ (1,58 $\mathrm{g} / 100 \mathrm{~g}$ ). No entanto, entre os ácidos graxos altamente poliinsaturados não foi observada a presença do EPA.

Marquez et al. (1989) relataram que salsichas com baixos teor de gordura, elaboradas com substituição de $60 \%$ da gordura tradicional da carne por óleo de amendoim, apresentaram menor estabilidade da emulsão, mais firme textura, e cor mais escura. Hammer (1992) produziu salsichas com óleo de oliva e girassol (25\% nível de gordura) e relataram que os produtos apresentaram cor mais clara. Paneras e Bloukas (1994) relataram que salsichas com baixo teor de gordura feitas com azeite, óleos de girassol, milho ou a soja apresentaram menor rendimento de processamento, cor mais escura, textura mais firme, menor suculência, bem como níveis mais baixos de ácidos graxos saturados, calorias e colesterol, em 
comparação com salsicha feitas com gordura suína. Hsu e Yu (2002) constataram que almôndegas com baixo teor de gordura elaboradas com 11 diferentes óleos vegetais, resultaram em similar propriedades texturais e qualidades sensoriais, em comparação às almôndegas elaboradas com gordura suína.

\subsection{TEOR DE COLESTEROL}

O colesterol é a matéria-prima para a síntese de hormônios e vitamina D3, sendo também o constituinte essencial das membranas celulares. É um componente importante da carne, o qual como outros derivados lipídicos, sofre oxidação catalisada pela ação de luz, ar, temperaturas elevadas, radicais livres ou combinações destes (PEARSON et al., 1983; MADRUGA et al., 2004).

O consumo de colesterol, aliado a determinadas condições de desequilíbrio hormonal, estresse e outros fatores pré-condicionantes, está relacionado à ocorrência de doenças em seres humanos, como a formação de cálculos biliares e insuficiência cardíaca. O colesterol participa na formação do sais biliares, e a principal via de excreção do colesterol é através da perda desses sais biliares que escapam à reabsorção no trato digestivo, porém esta fração é muito pequena. Metade do colesterol do organismo tem sua origem na produção endógena e o restante, nos alimentos ingeridos (LEHNINGER, 2000). Portanto, o conhecimento do teor de colesterol da dieta torna-se importante face à dificuldade, de excreção e aos problemas de saúde que podem ser originados pelo acúmulo desta substância nos tecidos humanos.

Os valores de colesterol para alguns cortes bovinos estão expressos na tabela 1. 
Tabela 1 - Concentração de colesterol $(\mathrm{mg} / 100 \mathrm{~g})$ na carne bovina

\section{Carne Bovina}

\section{Crua}

\begin{tabular}{cc}
\hline Contra Filé & $51 \pm 6$ \\
Coxão Duro & $56 \pm 6$ \\
Coxão Mole & $50 \pm 6$ \\
Músculo & $52 \pm 4$ \\
Peito & $51 \pm 6$ \\
\hline Fonte: adaptado de Bragagnolo e Rodriguez-Amaya (1995).
\end{tabular}

\section{Colesterol $(\mathbf{m g} / \mathbf{1 0 0 g})$}

Fonte: adaptado de Bragagnolo e Rodriguez-Amaya (1995).

Costa et al. (2002), verificaram valores de colesterol de $43,07 \mathrm{mg} / 100 \mathrm{~g}$ no músculo Longissimus dorsi em seu estado natural de umidade.

O teor de lipídios em um alimento é a forma como o mesmo se encontra e é de suma importância para a saúde do consumidor, sendo que uma taxa elevada de colesterol no sangue constitui um dos principais fatores de risco para doenças coronarianas. A Associação Americana do Coração recomenda a ingestão diária de $300 \mathrm{mg}$ de colesterol para um homem adulto (PEREIRA et al., 2000), porém estudos recentes recomendam um ingestão ainda menor de colesterol. Ramires (2009) recomendou uma ingestão diária de $180 \mathrm{mg}$ de colesterol.

\subsection{OXIDAÇÃO LIPÍDICA}

A oxidação lipídica é o principal processo pelo qual ocorre perda de qualidade das carnes e seus derivados, depois da deterioração microbiana. Tratase de um fator determinante para a vida útil do produto e limitante na qualidade e aceitabilidade, na medida em que gera produtos indesejáveis do ponto de vista sensorial, degrada vitaminas lipossolúveis e ácidos graxos essenciais e afeta atributos como sabor, cor, textura e valor nutritivo (OSAWA; FELícIO; GONÇALVES, 2005).

Além de componentes intrínsecos pró e antioxidantes do próprio músculo, um número de fatores extrínsecos influencia a oxidação lipídica da carne. Os fatores ambientais como temperatura, luz, nível de oxigênio, grau de insaturação 
dos ácidos graxos, presença de metais e enzimas afetam a suscetibilidade dos lipídios do músculo a oxidação (LEE; MEl; DECKER, 1996).

Entre as metodologias analíticas disponíveis para acompanhar e compreender o processo de oxidação lipídica em alimentos se destaca a determinação do valor de substâncias reativas ao ácido 2-tiobarbitúrico (TBARS). 0 método permite quantificar o grau de oxidação lipídica do alimento baseado na reação de cor entre o malonaldeído e o ácido 2-tiobarbitúrico (JO; AHN, 1998).

As substâncias reativas ao ácido 2-tiobarbitúrico são preferencialmente formadas a partir da clivagem de ácidos graxos com duplas ligações. Os hidroperóxidos formados podem originar compostos contendo grupamentos carbonílicos, sendo o malonaldeído o principal alcadienal relacionado com o processo de oxidação lipídica (TARLADGIS; WATTS; YOUNATHAN, 1960), este pode ocasionar distúrbios na saúde, como câncer, aterosclerose, dentre outros.

Os ácidos graxos insaturados da membrana celular são elementos suscetíveis ao ataque dos radicais livres $(\mathrm{HO} \bullet$ ou $\mathrm{HOO} \bullet)$ devido a suas estruturas químicas, que permite a retirada de átomos de hidrogênio de um dos grupos $-\mathrm{CH}_{2}$ da cadeia carbônica e a conseqüente formação de um radical livre (-C•-), iniciandose o processo de peroxidação lipídica (COMBS, 1992).

A oxidação lipídica pode resultar ainda em rancidez da carne, deterioração da cor, textura e sabor da carne fresca, congelada e cozida. Está diretamente relacionada com a oxidação do pigmento, contudo esta associação não está bem esclarecida. Do ponto de vista da cor da carne, pode ser que radicais produzidos durante a oxidação lipídica atuem diretamente, na oxidação do pigmento, danificando os sistemas de redução do pigmento (LIU et al., 1995). Além disso, a presença de agentes oxidativos na carne resulta no desenvolvimento de sabores estranhos na carne ("off-flavors") devido à oxidação das duplas ligações da gordura, denominada oxidação lipídica (autoxidação) juntamente com outros processos de degradação da carne armazenada e posteriormente cozida (TROUT, 2003).

Esse processo de degradação é importante não somente em relação à alteração da cor da carne, mas também em relação a outras características importantes, tais como, sabor, aroma, perdas por gotejamento e produção de compostos prejudiciais à saúde humana. 


\subsection{ANÁLISE SENSORIAL}

Testes afetivos são uma importante ferramenta, pois acessam diretamente a opinião (preferência e/ou aceitabilidade) do consumidor já estabelecido ou potencial de um produto, sobre características específicas do produto ou idéias sobre 0 mesmo e, por isso são também chamados de testes de consumidor. Os testes afetivos são usados principalmente por fabricantes de produtos de venda direta ao consumidor, mas podem também ser uma importante estratégica para fabricantes de ingredientes como aromas, corantes, aditivos, misturas de pré-preparo de alimentos dentre outros (FERREIRA, 2000).

A avaliação subjetiva de textura de carne é acompanhada simultaneamente de características incluindo maciez, suculência e fibras residuais. Destas, a maciez é a mais importante para o consumidor e exerce forte influência sobre a aceitabilidade destes produtos (SZCZESNIAK; TORGESON, 1965).

Escalas bipolares de oito ou nove pontos são as mais indicadas para carne e seus derivados por serem superiores explicativamente aos provadores, especificamente para os atributos de maciez e suculência, por exemplo, extremamente duro (um) e extremamente macia (nove), e extremamente seco (um) e extremamente suculento (nove) (SZCZESNIAK; TORGESON, 1965).

Em fast-foods frequentemente preparam-se bifes (reestruturados, nugetts, hambúrgueres, etc.) no estado congelado, já os consumidores usualmente os cozinham na forma resfriada ou descongelada (AMSA, 1995). As diretrizes da AMSA (1995) sugerem que independente do tipo de carne e/ou produto avaliado, deve-se utilizar métodos de cocção comuns aos praticados pelos consumidores.

A preferência para carne é mais fortemente afetada por mudanças na aparência preferivelmente cor e na textura, e em menor extensão por mudanças no sabor. É difícil generalizar se os atributos de aparência ou de textura são os mais importantes. Os atributos de aparência, incluindo cor, descrevem grande parte das variações no material, porém alguns atributos são confundidos com os de textura (RIVISK, 1994).

Estudos com consumidores demonstram que a maciez é um fator muito importante de qualidade quando se considera a qualidade geral de carne e seus produtos. Os mm. Psoas major e Longissimus dorsi são considerados os mais 
macios e de alta qualidade. Embora bifes provenientes de músculos do quarto dianteiro, como os mm. Biceps femoris e Supraspinatus sejam classificados como duros outros cortes como m. Infraspinatus possuem maciez intermediária (HUFFMAN et al., 1996).

Ruiz et al. (1993) avaliaram sensorialmente carne bovina reestruturada produzida a partir de 10 músculos e relataram que os $\mathrm{mm}$. Infraspinatus, Triceps brachii, Biceps brachii e Supraspinatus são de fácil utilização por serem de fácil identificação, acessibilidade, e apresentam alto rendimento de desossa, em torno de $75 \%$. Ruiz et al. (1993) e Carmack et al. (1995) descreveram que em geral, os músculos provenientes do quarto dianteiro (especialmente da paleta) são considerados mais suculentos e palatáveis que alguns músculos provenientes do coxão. Carmack et al. (1995) avaliaram 12 músculos utilizando escala de 10 pontos (1-menos macia, a 10-mais macia), dentre eles os $\mathrm{mm}$. Supraspinatus, Infraspinatus e Triceps brachii observaram que as médias em relação à maciez para $0 \mathrm{~m}$. Infraspinatus foi de $7,2\left(2^{\circ}\right.$ colocado na classificação entre 12 músculos examinados), m. Triceps brachii 5,8 (7 $7^{\circ}$ colocado) e m. Supraspinatus 5,1 ( $8^{\circ}$ colocado). Em relação à suculência, o m. Infraspinatus apresentou média de 6,6 ( $2^{\circ}$ colocado na classificação entre 12 músculos), m. Supraspinatus 5,1 ( $6^{\circ}$ colocado) e m. Triceps brachii 4,9 (7 colocado).

Em um estudo avaliando-se as variações nas características sensoriais de 11 músculos, os m.Infraspinatus e Triceps brachii apresentaram as melhores notas na avaliação de maciez geral e suculência entre os músculos avaliados, de acordo com Rhee et al. (2004).

Óleos vegetais diferem consideravelmente em relação a cor e sabor (SWERN, 1964) e podem afetar as características de qualidade de produtos cárneos. Produtos cárneos com porcentagens baixas de gordura são muitas vezes rejeitados pelo consumidor, porque eles são considerados menos aceitáveis em sabor e textura em comparação aos produtos tradicionais (KEETON, 1994). Portanto, o fator mais importante durante a substituição da gordura animal por óleo vegetal é não causar alterações de qualidade indesejadas (ZORBA; KURT, 2008). 


\subsection{COR INSTRUMENTAL}

As carnes são compostas de quatro tipos básicos de tecidos, ou seja, tecido muscular, tecido epitelial, tecido nervoso e tecido conjuntivo. O principal componente da carne é o músculo. As proteínas do músculo podem ser divididas em três classes: sarcoplasmáticas, miofibrilares e estromáticas. Dentre as proteínas sarcoplasmáticas destaca-se a mioglobina, a qual é responsável pela respiração do tecido muscular e pela coloração vermelha dos músculos (SGARBIERI, 1996). A quantidade de mioglobina varia de acordo com músculo, espécie e idade do animal (COULATE, 1984).

A cor é um atributo sensorial importante dos alimentos, influindo de forma decisiva na sua aceitação. O consumidor aprende a associar a boa qualidade de um alimento com uma determinada cor que Ihe é característica (SGARBIERI, 1996).

A cor natural das carnes vermelhas é dada pelas proteínas hemoglobina e mioglobina em suas formas oxigenadas (oxihemoglobina $\mathrm{HbO}_{2}$ e oximioglobina $\mathrm{MbO}_{2}$ ) (SGARBIERI, 1996). Estes pigmentos podem reagir com diversos substratos resultando em alterações na sua cor (FORREST et al., 1979; FRANCO, 2003).

A mioglobina é formada por uma porção protéica, denominada globina, e uma porção não protéica, denominada anel ou grupo heme. No centro do grupo heme há um átomo de ferro. A hemoglobina é formada por quatro mioglobinas unidas. Ela forma complexos reversíveis com o oxigênio no pulmão. Estes complexos são distribuídos pelo sangue para os diversos tecidos do animal, onde o oxigênio é absorvido. A mioglobina absorve o oxigênio transportado pela hemoglobina, armazena nos tecidos e o coloca a disposição do metabolismo (FORREST et al., 1979; FENNEMA, 2000).

O átomo de ferro do grupo heme tem seis ligações coordenadas, capazes de aceitar seis pares de elétrons. Quatro pares vêm dos átomos de nitrogênio do núcleo porfirínico, um par provém do $\mathrm{N}$ do anel imidazólico da histidina, o sexto par de elétrons está disponível para formar ligação coordenada com um ligante que determina a cor do complexo. Este ferro pode se encontrar reduzido (ferroso +2 ) ou oxidado (férrico +3 ), estando oxidado não tem a capacidade de ligar-se a outras 
moléculas, inclusive o oxigênio molecular e estando reduzido, reage facilmente com a água e com o oxigênio. Quando a mioglobina, com o ferro no estado ferroso, se une ao oxigênio molecular e forma-se a oximioglobina $\left(\mathrm{MbO}_{2}\right)$, denomina-se de oxigenação. Quando o ferro ferroso se converte em férrico e forma-se metamioglobina $(\mathrm{MMb})$, denomina-se de oxidação da mioglobina. O tecido que foi oxigenado possui cor vermelho brilhante comum. Já o tecido que foi oxidado possui uma cor marrom, que não é desejável. As reações de cor da carne fresca são dinâmicas e determinadas pelo estado do músculo e as porções resultantes de mioglobina, metamioglobina e oximioglobina (SGARBIERI, 1996; FENNEMA, 2000).

A alteração da cor da carne pode ser conseqüência da destruição da mioglobina pelo desenvolvimento bacteriano. Os microrganismos utilizam a mioglobina como nutriente e o grupo hemo se separa da proteína. Assim, desenvolve-se uma coloração verde, que também pode ocorrer devido o crescimento de microrganismos no centro do produto, onde o baixo potencial de óxido-redução propicia o acúmulo de peróxido de hidrogênio. $O$ microrganismo mais comum nesse tipo de esverdeamento é o Lactobacillus viridescens. Esta deterioração pode ainda ser causada por bactérias produtoras de peróxido de hidrogênio como Lactobacillus fructivorans e Lactobacillus jensenii. A produção de $\mathrm{H}_{2} \mathrm{~S}$ ocorre geralmente em carnes frescas quando armazenadas em embalagens a vácuo ou impermeáveis a trocas gasosas e mantidas entre $1^{\circ} \mathrm{C}$ e $5^{\circ} \mathrm{C}$, reagindo com a mioglobina, formando a sulfomioglobina de coloração verde. Entre os microrganismos causadores dessa alteração, estão Pseudomonas mephitica, Shewanella putrefaciens e Lactobacillus sake. (FORREST et al., 1979; FRANCO, 2003).

Mancini e Hunt (2005), em revisão sobre cor, afirmaram que a decisão de compra de carne é mais influenciada no primeiro momento pela cor e os consumidores as usa como um indicador de frescor e sanidade. Desta forma, é necessário utilizar uma matéria-prima o mais fresca possível para a fabricação de seus produtos, pois os processos de manipulação e corte promovem maior exposição desta ao oxigênio e pode resultar em um produto com menor vida útil, devido à descoloração. 
Velho et al. (2009) avaliaram o perfil de consumidores de carne bovina e observaram que apesar da baixa renda familiar entre as pessoas questionadas, 0 atributo que mais determina a compra de carne bovina pelos consumidores é a cor. Segundo esse autor, a cor é o atributo mais facilmente perceptível pelo consumidor.

Grunert (1997) analisou como os consumidores avaliam a qualidade da carne bovina em situações de compra na França, Alemanha, Espanha e Inglaterra e concluiu que a avaliação da qualidade é baseada na coloração e conteúdo de gordura da carne, não havendo percepção da relação positiva e direta entre gordura e gosto/maciez. Informações sobre o país de origem, raça e alimentação não possuem efeito sobre a percepção de qualidade da carne por parte dos consumidores pesquisados.

Youssef e Barbut (2011) estudaram os efeitos de redução de gordura e substituição da gordura da carne com óleo de canola ou pré-emulsão óleo de canola e observaram um aumento nos valores de luminosidade e redução do vermelho com o aumento teor de óleo de canola.

\subsection{TEXTURA INSTRUMENTAL}

Por definição, a textura é um atributo que resulta da combinação de todas as propriedades reológicas e estruturais (geométricas e de superfície) de um alimento, perceptível pelos receptores mecânicos, táteis, e eventualmente pelos receptores visuais e auditivos (ABNT, 1993).

Em todo o mundo a qualidade da carne bovina caracteriza-se por ser extremamente inconsistente, sendo a maciez a característica que apresenta a maior variabilidade (RUBENSAM, 1999).

Pesquisas têm sido realizadas enfocando a qualidade de carne bovina nos últimos 20 anos e a maciez é sempre apontada como fator essencial para o julgamento da qualidade do produto (KOOHMARAIE, 1994). Vários fatores influenciam a textura final da carne. Entre eles, destacam-se a maturidade (CULLER et al., 1978), a quantidade e natureza química do colágeno (BAILEY, 1972), a raça, a extensão da proteólise pós-abate (DRANSFIELD, 1994), a 
velocidade de queda do $\mathrm{pH}$, a temperatura da carne no momento do rigor mortis (MARSH, 1977) e os métodos de preparo culinário (APPLE et al., 1999).

O método mais utilizado para se avaliar a textura da carne é o de força de cisalhamento com uso da lâmina de Warner-Bratzler. Outro método existente, porém ainda pouco utilizado para medir a textura da carne, mas muito utilizado em outros alimentos, é a análise do perfil de textura também conhecido como TPA (texture profile analysis), por meio de compressão do alimento com auxílio de uma probe cilíndrica.

Os métodos instrumentais de análise de textura avaliam propriedades mecânicas a partir de forcas aplicadas ao alimento tais como compressão, cisalhamento, corte e tensão. A análise do perfil de textura (TPA) instrumental aplica sucessivas forças deformantes, numa simulação da ação de compressão e corte dos dentes durante a mastigação (LI et al., 1998). A maior vantagem da avaliação do TPA seria que com esta pode-se aferir muitas outras variáveis no segundo ciclo de compressão, como: dureza, elasticidade, coesividade, adesividade, fraturabilidade, resiliência, gomosidade, mastigabilidade, entre outras (HUIDOBRO et al., 2005).

Em se tratando de perfil de textura de carne, os parâmetros aplicáveis a estes produtos foram descritos por Szczesniak e Torgesen (1965) e definidos por Bourne (1982), como segue:

_ Dureza: representada pela altura do primeiro pico. É a força máxima alcançada na primeira compressão para produzir uma deformação. Relaciona-se a força dentro da boca requerida para comprimir uma substância entre os dois dentes molares ou entre a língua e o palato.

_ Elasticidade: grau com o qual um produto volta a sua forma original, depois da primeira compressão e antes da segunda, ou a velocidade em que um material deformado volta à condição não deformada, depois que a força de deformação é removida.

_ Coesividade ou gomosidade: densidade que persiste quando se mastiga para transformar um alimento semi-sólido a um estado pronto para ser deglutido. Grau com o qual uma substância é comprimida entre os dentre antes de romper.

_ Mastigabilidade: espaço de tempo requerido para mastigar uma amostra, a uma velocidade constante de aplicação de força, para reduzi-la a consistência adequada para deglutição. 
Especificamente, em carnes reestruturadas, a textura pode ser muito variada devido à variedade da matéria-prima utilizada e dos diferentes processos de fabricação (PEARSON; DUTSON, 1987). Uma alternativa para medição da textura (força de cisalhamento) de produtos onde há uma grande discrepância na textura ao longo do bife é o teste de cisalhamento utilizando uma célula de corte plano, utilizada por Olivo (1999) em peito de aves, e foi descrita por Shackelford; Wheeler; Koohmaraie (2003). 


\section{MATERIAL E MÉTODOS}

\subsection{LOCAL E OBTENÇÃO DE MATÉRIA-PRIMA}

O projeto foi desenvolvido na Faculdade de Medicina Veterinária e Zootecnia (FMVZ) da Universidade de São Paulo (USP), Campus de Pirassununga - SP.

Os cortes cárneos foram doados pela empresa VPJ Alimentos, oriundos de fêmeas meio sangue Angus e meio sangue Nelore, de aproximadamente 18 meses de idade. A enzima transglutaminase foi doada pela empresa All Taste.

O processamento tecnológico foi realizado no Abatedouro-Escola da Prefeitura do Campus de Pirassununga - SP. As provas microbiológicas foram realizadas pelo Laboratório de Análises Físico-químicas e Microbiológicas Ltda. (Microbial), credenciado pelo Ministério da Agricultura, Pecuária e Abastecimento, em Campinas - SP. As avaliações da composição centesimal, pH e análises instrumentais de cor foram realizadas no Laboratório de Bromatologia, do Departamento de Nutrição e Produção Animal (VNP), na FMVZ/USP. As análises de textura foram realizadas no Laboratório de Carnes e derivados, no Departamento de Tecnologia de Alimentos, na Faculdade de Engenharia de Alimentos da UNICAMP, em Campinas - SP. As análises de colesterol e o valor de TBARS foram realizados no Laboratório de Química, FZEA/USP. As análises sensoriais com painel de consumidores e as análises de perdas ao cozimento foram realizadas na empresa VPJ Alimentos, em Pirassununga - SP.

\subsection{DELINEAMENTO EXPERIMENTAL}

Foram utilizados 4 tratamentos para avaliação das variáveis relacionadas à textura da carne, composição centesimal e colesterol, um delineamento inteiramente casualizado (DIC) e para avaliação dos parâmetros de cor $\left(\mathrm{L}^{*}, \mathrm{a}^{*}\right.$ e b*), $\mathrm{pH}$, perdas ao cozimento, exsudação no descongelamento, análises sensoriais, 
tbars, bem como, as variáveis relacionadas aos aspectos microbiológicos, segundo os tratamentos e tempos, foram adotados um delineamento inteiramente casualizado (DIC), em esquema fatorial $4 \times 3$ ou $4 \times 5$, ou seja, utilizando-se óleo de canola ou antioxidante, utilizando-se os dois e controle, testados em 3 ou 5 tempos.

Para obtenção da comparação entre as médias dos tratamentos e uma estimativa de erro experimental, cada tratamento foi submetido a 5 repetições.

\subsection{FORMULAÇÃO DA CARNE REESTRUTURADA E TRATAMENTOS}

A carne reestruturada foi elaborada a partir do músculo Triceps brachii (miolo da paleta), doado pelo frigorífico VPJ Alimentos, em Pirassununga-SP. O óleo de canola utilizado foi da marca Liza (Cargill) e a enzima transglutaminase (Saprona TG F) foi doada pela All Taste.

Foram desenvolvidos quatro tratamentos de carne reestruturada bovina: (1) controle; (2) adição de 5\% de óleo de canola; (3) adição de eritorbato de sódio; (4) adição de $5 \%$ de óleo de canola e eritorbato de sódio.

Em todos os tratamentos foram adicionados $8 \%$ água, $1 \% \mathrm{NaCl}$ e $0,3 \%$ tripolifosfato de sódio, $1 \%$ de enzima transglutaminase e $10 \%$ de gordura bovina. Os ingredientes e percentuais utilizados nos tratamentos estão apresentados na tabela 2.

Tabela 2 - Formulação dos diferentes tratamentos de carne reestruturada bovina.

\begin{tabular}{cccccccccc}
\hline Tratamento & $\begin{array}{c}\text { Carne } \\
\mathbf{( g )}\end{array}$ & $\begin{array}{c}\text { Gordura } \\
\mathbf{( g )}\end{array}$ & $\begin{array}{c}\text { Sal } \\
\mathbf{( g )}\end{array}$ & $\begin{array}{c}\text { Tripoliofosfato } \\
\mathbf{( g )}\end{array}$ & $\begin{array}{c}\text { Oleo } \\
\mathbf{d e} \\
\text { Canola } \\
\mathbf{( g )}\end{array}$ & $\begin{array}{c}\text { Água } \\
\mathbf{( g )}\end{array}$ & $\begin{array}{c}\text { Enzima } \\
\mathbf{( g )}\end{array}$ & $\begin{array}{c}\text { Eritorbato } \\
\text { de sódio } \\
\mathbf{( g )}\end{array}$ & $\begin{array}{c}\text { Total } \\
\mathbf{( g )}\end{array}$ \\
\hline 1 & 7970 & 1000 & 10 & 30 & - & 800 & 100 & - & 10.000 \\
2 & 7470 & 1000 & $\begin{array}{c}10 \\
0\end{array}$ & 30 & 500 & 800 & 100 & - & 10.000 \\
3 & 7965 & 1000 & $\begin{array}{c}10 \\
0\end{array}$ & 30 & - & 800 & 100 & 5 & 10.000 \\
4 & 7465 & 1000 & $\begin{array}{c}10 \\
0\end{array}$ & 30 & 500 & 800 & 100 & 5 & 10.000 \\
\hline
\end{tabular}


Oitenta por cento da carne magra foi picada em disco de rim (aproximadamente $2 \mathrm{~cm}$ ), os $20 \%$ de carne bovina restante e os $10 \%$ de gordura da fraldinha foram moídos em disco $3 \mathrm{~mm}$ de diâmetro a uma temperatura entre 0 a $4^{\circ} \mathrm{C}$, para melhor homogeneização (Figuras 1, 2 e 3).

Figura 1 - Carne moída disco 3mm

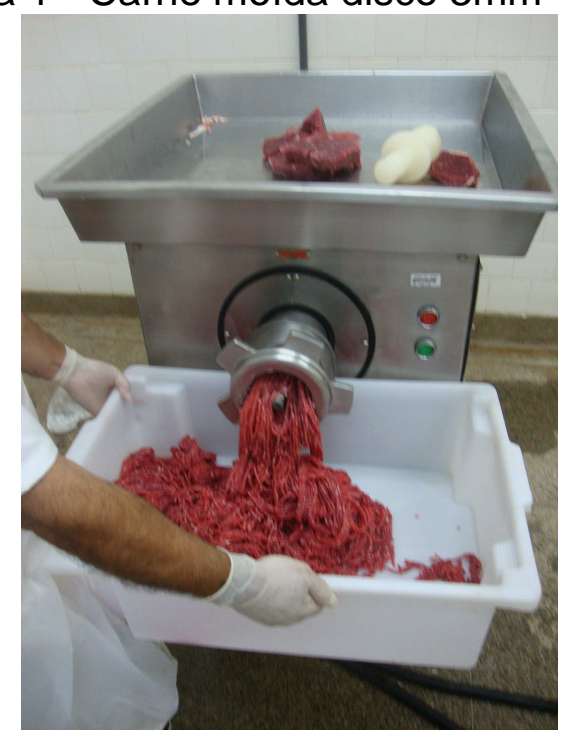

Figura 2 - Carne picada no disco de rim

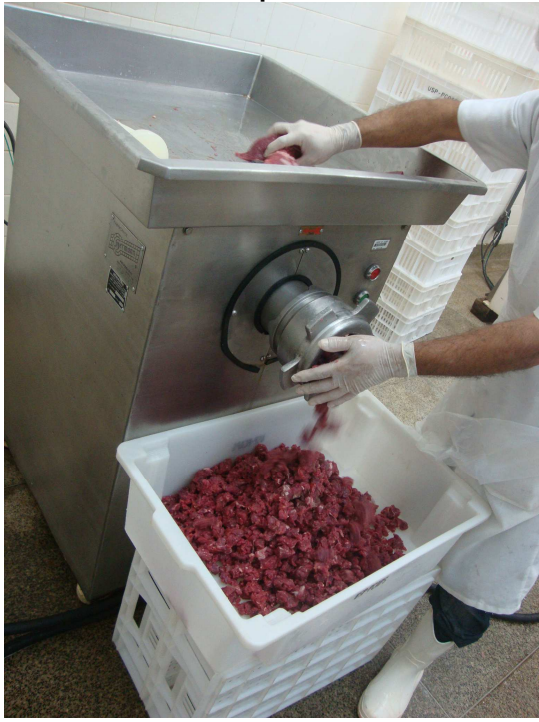

Figura 3 - Adição de ingredientes no misturador

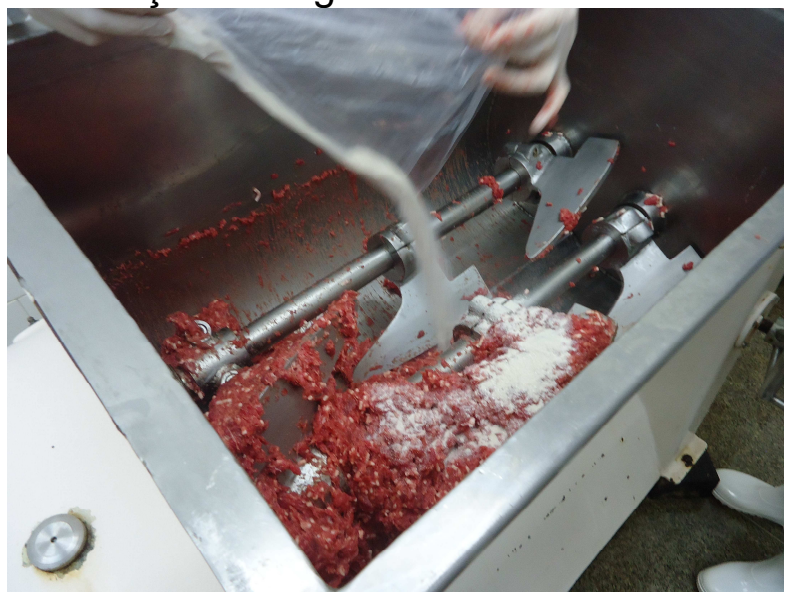

No tratamento controle (1), a carne magra picada e a gordura moída foram colocadas no misturador, onde se adicionou os ingredientes água, sal e tripolifosfato de sódio, misturou-se por 3 minutos (CHEN; TROUT, 1991) e por último a enzima MTGase foi adicionada a seco e misturou-se por mais 3 minutos, para promover a coesão entre os pedaços de carne.

Nos tratamentos com antioxidante (3 e 4), 0,05\% de eritorbato de sódio foi acrescentado junto aos primeiros ingredientes no misturador. Nos tratamentos com 
adição de óleo de canola (2 e 4) uma porção de $20 \%$ da carne e gordura foi levada ao cutter para uma emulsão com o óleo de canola e $20 \%$ de água. Após a emulsão, a porção emulsionada foi adicionada ao restante da carne já misturada à salmoura por 1 minuto e misturou-se por 2 minutos, totalizando 3 minutos. Da mesma forma que para o controle, nos tratamentos 2, 3 e 4 a enzima MTGase foi adicionada a seco por último e misturou-se por mais 3 minutos.

A mistura obtida por meio dos processamentos foi embutida em embalagens de presunto, colocadas em formas quadradas e prensadas, deixadas sob refrigeração para atuação da enzima por 6 horas. Após este período os blocos foram congelados. Depois de congelados os blocos foram desenformados e cortados congelados em serrafita com $2,5 \mathrm{~cm}$ de espessura e as amostras identificadas, embaladas individualmente a vácuo e mantidas congeladas com temperatura de aproximadamente $-18^{\circ} \mathrm{C}$, por um mês (30 dias), 2 meses (60 dias), 3 meses (90 dias) e 4 meses (120 dias), com o objetivo de avaliar a vida útil desses bifes.

\subsection{ANÁLISES FÍSICO-QUÍMICAS NA MATÉRIA-PRIMA E NA CARNE REESTRUTURADA}

As análises físico-químicas foram realizadas de acordo com a metodologia descrita pela Instrução Normativa n.20 de 21/07/2001 do Ministério da Agricultura e do Abastecimento (1999), que oficializa os métodos analíticos físico-químicos para controle de produtos cárneos e ingredientes. Essa metodologia consiste fundamentalmente nos procedimentos de análises publicados pela Association of Analytical Chemists (1998).

Foram analisados no músculo Triceps brachii (miolo da paleta) e nos 4 tratamentos de bife reestruturado cru os seguintes parâmetros físico-químicos para determinar a composição centesimal: umidade - método gravimétrico (estufa); proteínas - método de Kjeldahl; lipídeos - método de Bligh e Dyer e cinzas método de mufla;

$\mathrm{O} \mathrm{pH}$ foi mensurado misturando-se em um béquer de $50 \mathrm{~mL}, 30 \mathrm{~g}$ de amostra homogeneizada com 6 - $10 \mathrm{~mL}$ de água destilada ou deionizada, para 
possibilitar a penetração do eletrodo e realizando-se a leitura com pHmetro previamente calibrado;

A perda ao cozimento foi determinada pesando-se a amostra antes (p1) e depois (p2) do cozimento e aplicando-se a seguinte equação: Perdas no cozimento $(\%)=100 *(p 1-p 2) / p 1$.

A perda por exsudação durante o descongelamento foi determinada pela subtração do peso antes (p1) e depois (p2) do descongelamento.

Determinou-se as substâncias reativas ao ácido tiobarbitúrico (valor TBARS, expresso em $\mathrm{mg}$ de malonaldeído/kg de amostra, por meio do método descrito por Sorensen e Jorgensen (1996), Vyncke (1970) e Vyncke (1975).

O colesterol foi determinado por meio do método adaptado, segundo Saldanha, Mazalli e Bragagnolo (2004).

\subsection{ANÁLISES MICROBIOLÓGICAS}

Foram realizadas as análises microbiológicas em amostras da matéria-prima inicial utilizada e nos tratamentos de carne reestruturada no início e no final do experimento, visando à caracterização da matéria-prima e do produto e a garantia de qualidade e segurança ao consumidor, de acordo com a legislação brasileira.

As análises microbiológicas foram conduzidas de acordo com a Agência Nacional da vigilância Sanitária (2001) para carnes e produtos cárneos. Para produtos cárneos resfriados ou congelados e/ou pré-cozidos e congelados utilizando como matéria-prima a carne bovina são exigidas análises de Salmonella $\mathrm{sp}$, Coliformes a $45^{\circ} \mathrm{C} / \mathrm{g}$, Staphylococcus coagulase positiva/g e Clostridium sulfito redutor a $46^{\circ} \mathrm{C} / \mathrm{g}$, na matéria-prima são exigidas análises de Salmonella sp.

\subsection{ANÁLISE INSTRUMENTAL DE COR}

Para avaliação instrumental de cor as amostras foram descongeladas sob refrigeração com temperatura entre 0 a $5^{\circ} \mathrm{C}$ por 12 horas, desembaladas e 
colocadas em bandejas de alumínio, após 20 minutos de exposição dos cortes ao oxigênio foi realizada a medição. Na superfície de cada bife realizou-se 3 medições, utilizando-se espectrofotômetro portátil MINOLTA, operando no sistema CIE (Comission Internacionale d'le Ecleraige) $\mathrm{L}^{*} \mathrm{a}^{*} \mathrm{~b}^{*}$ ( $\mathrm{L}^{*}$ luminosidade, $\mathrm{a}^{*}$ intensidade de cor vermelha, $b^{*}$ intensidade de cor amarela).

\subsection{ANÁLISE INSTRUMENTAL DE TEXTURA}

A textura da carne reestruturada, após grelhada, foi avaliada pela técnica denominada análise do perfil de textura - TPA (BOURNE, 1978). As amostras foram descongeladas, sob refrigeração, com temperatura entre 0 a $5^{\circ} \mathrm{C}$, por 12 horas, assadas em chapa elétrica a $180^{\circ} \mathrm{C}$, até atingirem a temperatura interna do bife de $71^{\circ} \mathrm{C}$, monitorada com termopares, em seguida esperou-se resfriar até atingir temperatura de $8^{\circ} \mathrm{C}$ (Figura 4).

Figura 4 - Bife sendo grelhados em chapa elétrica

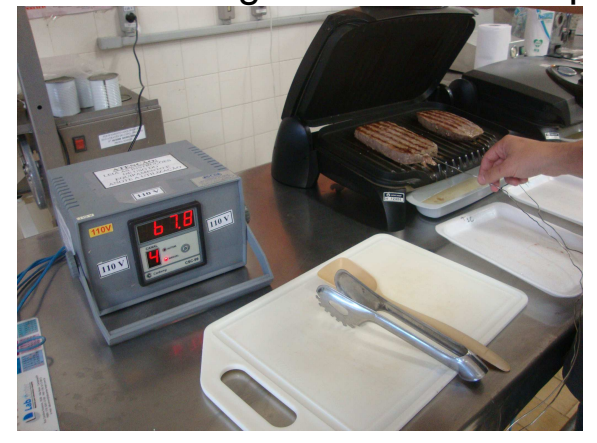

A análise TPA avalia os parâmetros de dureza, elasticidade, coesividade, e mastigabilidade (BOURNE, 1978), com velocidade de $3,4 \mathrm{~mm} / \mathrm{s}$ e compressão de $75 \%$ da altura das amostras, utilizando a probe P35 (FLORES; BOYLE; KASTNER, 2007). Foram retirados 3 cilindros de $2,5 \mathrm{~cm}$ de diâmetro por $2 \mathrm{~cm}$ de espessura de cada bife (Figura 5). 


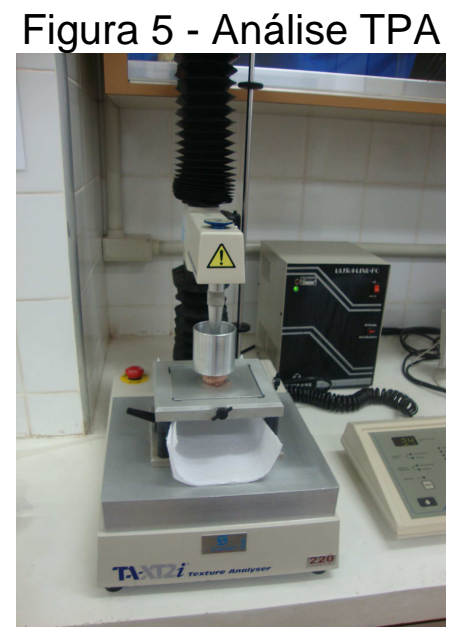

A textura da carne também foi avaliada por meio do teste de cisalhamento, com célula de corte plano (Figura 6), utilizando metodologia descrita por Shackelford, Wheeler e Koohmaraie (2003), com velocidade de $10 \mathrm{~mm} / \mathrm{s}$ e utilizando $25 \mathrm{~mm}$ de profundidade (OLIVO, 1999). Para está análise, as amostras foram grelhadas da mesma forma que as amostras na análise de TPA, sendo depois retiradas 3 fatias de $1 \mathrm{~cm}$ de espessura, $5 \mathrm{~cm}$ de comprimento e $2 \mathrm{~cm}$ de largura de cada bife.

Figura 6 - Análise de cisalhamento com célula de corte plano

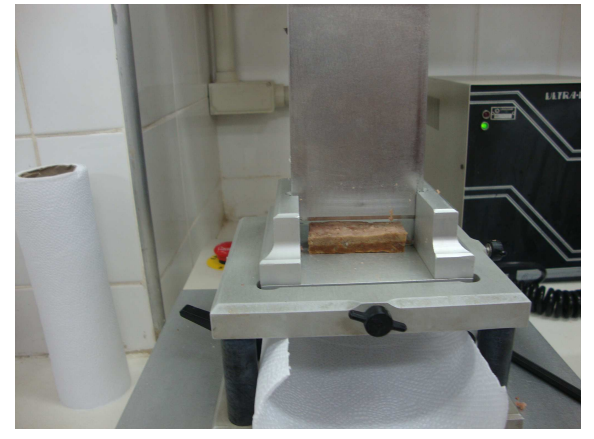

Ambas as análises de TPA e cisalhamento foram realizadas utilizando 0 texturômetro TA-TX2 (Stable Micro Systems Ltda.) com célula de carga de 5kg. A coleta dos dados e a construção das curvas de TPA foram efetuadas pelo programa Texture Expert, versão 1.1 (Stable Micro Systems). 


\subsection{ANÁLISE SENSORIAL}

A análise sensorial foi realizada utilizando-se testes afetivos quantitativos de aceitabilidade (MEILGAARD et al., 1999), com consumidores, onde as amostras foram avaliadas quanto à aceitabilidade do produto para os atributos de aroma, maciez, suculência e sabor (Figura 7).

Figura 7 - Análise sensorial

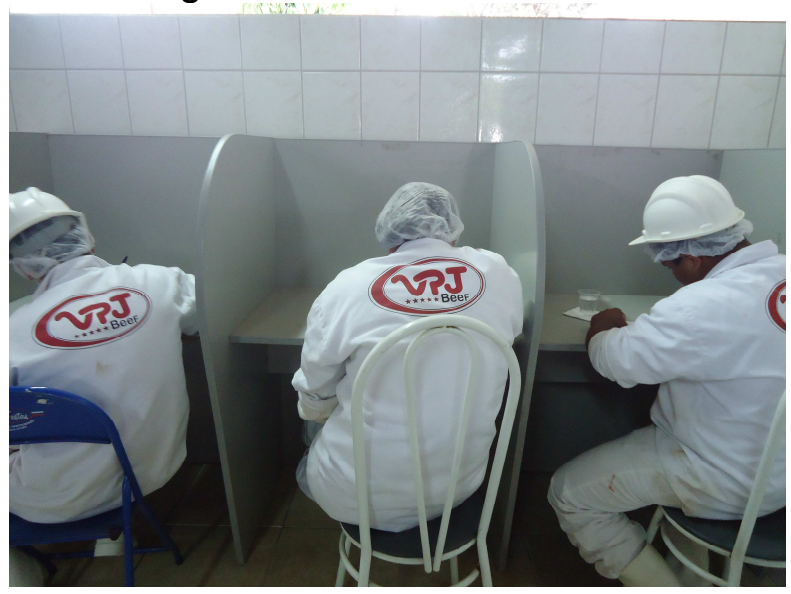

Para avaliação sensorial, os bifes reestruturados foram descongelados sob refrigeração com temperatura entre 0 a $5^{\circ} \mathrm{C}$ por 12 horas, até temperatura de 2$4^{\circ} \mathrm{C}$, assados em chapa elétrica a $180^{\circ} \mathrm{C}$ até atingirem temperatura interna do produto $71^{\circ} \mathrm{C}$ (AMSA, 1995), monitorada com termopares. Em seguida, as amostras foram porcionadas $(1,5 \mathrm{~cm}$ de espessura $\times 1 \mathrm{~cm}$ de comprimento $\times 1 \mathrm{~cm}$ de largura).

Os testes foram conduzidos em cabines individuais em três tempos (0, 60 e 120 dias), em média com 57 provadores. As amostras foram codificadas com número de três dígitos e fornecidas uma de cada vez aos provadores de acordo com o balanceamento das amostras (FERREIRA et al., 2000). Os consumidores avaliaram as amostras e registraram suas notas em fichas utilizando-se escala hedônica de nove pontos ( $9=$ gostei muitíssimo, $5=$ não gostei nem desgostei e 1=desgostei muitíssimo) e a intenção de compra através de escala de cinco pontos (5=certamente compraria, $3=$ talvez comprasse, talvez não comprasse, 
$1=$ certamente não compraria). Foi oferecido água mineral natural para uso antes e entre as amostras, visando limpar o palato.

Além das questões relacionadas à avaliação dos produtos, os consumidores responderam às questões sobre hábitos de consumo de carne bovina e características pessoais relacionadas à idade, definição de classe social e escolaridade. Todos os questionários utilizados encontram-se no anexo 1.

\subsection{ANÁLISE ESTATÍSTICA DOS RESULTADOS}

Para avaliação das variáveis relacionadas à textura da carne, composição centesimal e colesterol foi adotado um delineamento inteiramente casualizado (DIC), de acordo com o modelo "1" abaixo especificado:

Modelo "1":

$$
Y_{i j}=\mu+T_{i}+e_{i j}
$$

em que,

$\mathrm{Y}_{\mathrm{ijkl}}=$ é o valor observado para a variável em questão na repetição i e do tratamento i;

$\mu=$ constante inerente a todas as observações (média);

$\mathrm{T}_{\mathrm{i}}=$ é o efeito do $\mathrm{i}$-ésimo tratamento, sendo $\mathrm{i}=1$ (controle), 2 ( $5 \%$ de óleo de canola), 3 (Antioxidante eritorbato de Sódio) e 4 (Antioxidante $+5 \%$ óleo de canola) ;

$\mathrm{e}_{\mathrm{ij}}=$ é o erro experimental associado a repetição $\mathrm{i}$, e que recebeu o tratamento $\underline{\mathrm{i}}$, suposto NIID $\left(0, \sigma_{e}^{2}\right)$.

Para este modelo, no caso de efeito principal significativo, foram utilizados contrastes específicos avaliados por meio do teste $t$ de Student. Os contrastes a serem testados foram: (i) 1(Controle) versus 2, 3 e 4 (demais tratamentos); (ii) 4(Antioxidante eritorbato de Sódio + 5\% óleo de canola) versus 2 e 3 (Antioxidante eritorbato de Sódio e 5\% óleo de canola); e, (iii) eritorbato de Sódio (3) versus 5\% óleo de canola (2).

Para avaliação dos parâmetros de cor $\left(\mathrm{L}^{*}, \mathrm{a}^{*} \mathrm{e} \mathrm{b}^{*}\right), \mathrm{pH}$, perdas no cozimento, exsudação no descongelamento, T-bars, bem como, as variáveis relacionadas aos aspectos microbiológicos, segundo os tratamentos e tempos, foi adotado um 
Delineamento Inteiramente Casualizado (DIC), em esquema fatorial $4 \times 5$ de acordo com o modelo "2" abaixo especificado:

$$
\text { Modelo "2" : } \quad Y_{i j k l m}=\mu+T_{i}+D_{j}+T D_{i j}+e_{i j k}
$$

em que,

$Y_{\mathrm{ijk} k \mathrm{~m}}=\mathrm{e}$ o valor observado para a variável em estudo na repetição $\underline{\mathrm{k}}$, no díade avaliação i, e no tratamento i ;

$\mu=$ constante inerente a todas as observações (média);

$\mathrm{T}_{\mathrm{i}}$ = é o efeito do $\mathrm{i}$-ésimo tratamento, sendo $\mathrm{i}=1$ (controle), 2 ( $5 \%$ de óleo de canola), 3 (Antioxidante eritorbato de Sódio) e 4 (Antioxidante $+5 \%$ óleo de canola) ;

$D_{j}=$ é o efeito do j-ésimo dia de avaliação, sendo que para os parâmetros de cor $\left(\mathrm{L}^{*}, \mathrm{a}^{*} \mathrm{e} \mathrm{b}^{*}\right), \mathrm{pH}$, perdas no cozimento, exsudação no descongelamento e parâmetros microbiológicos $\mathrm{j}=1$ ( 0 dias), 2 (60 dias) e 3 (120 dias). Já para os parâmetros de t-bars j = 1 (0 dias), 2 (30 dias), 3 (60 dias), 4 (90 dias) e 5 (120 dias).

$T D_{i j}=$ e o efeito da interação do tratamento i com o dia de avaliação j;

$e_{i j k}=$ e o erro experimental associado a repetição a repetição $\underline{k}$, no dia de avaliação I, e no tratamento i, suposto NIID $\left(0, \sigma_{\mathrm{e}}{ }^{2}\right)$.

Para este modelo estatístico avaliado, no caso em que o efeito principal de tratamentos foi significativo, foi utilizado como procedimento de comparações múltiplas o teste $t$ de Student avaliando-se os contrastes acima descritos. Caso o efeito principal de tempo (dias de avaliação) foi significativo, foram utilizadas análises de regressão. Em caso de interações significativas, foram realizados os dois tipos de desdobramentos:

(i) Desdobramento visando avaliar os tratamentos dentro de cada tempo: foi utilizado o Teste $\mathrm{F}$ e, quando necessário, foi aplicado o teste $t$ de Student dentro de cada tempo significativo;

(ii) Desdobramento visando avaliar efeitos dos tempos dentro de cada tratamento avaliado; neste caso, após o teste $F$, foram realizadas as análises de regressão para cada tratamento devido à Interação entre os fatores.

Para avaliação dos diferentes atributos obtidos na análise sensorial (aroma, maciez, suculência e sabor), foram utilizados modelos mistos de acordo com os 
efeitos fixos utilizados no Modelo "2", com a inclusão do efeito aleatório dos provadores, de acordo com as recomendações de O'Mahony (1986).

Todas as análises foram realizadas com auxílio do programa Statistical Analysis System $^{\odot}$, versão 9.1.3 (SAS, 1995), utilizando-se o procedimento o PROC MIXED. 


\section{RESULTADOS E DISCUSSÃO}

\subsection{COMPOSIÇÃO CENTESIMAL E PH}

Os resultados de umidade, lipídios, proteínas, cinzas e $\mathrm{pH}$ final da matériaprima, músculo Triceps brachii (miolo da paleta) estão apresentados na tabela 3, a fim de caracterização do músculo.

Tabela 3 - Médias das análises físico-químicas do músculo Triceps brachii

\begin{tabular}{cccccc}
\hline Músculo & $\begin{array}{c}\text { Umidade } \\
(\mathrm{g} / 100 \mathrm{~g})\end{array}$ & $\begin{array}{c}\text { Lipídios } \\
(\mathrm{g} / 100 \mathrm{~g})\end{array}$ & $\begin{array}{c}\text { Proteínas } \\
(\mathrm{g} / 100 \mathrm{~g})\end{array}$ & $\begin{array}{c}\text { Cinzas } \\
(\mathrm{g} / 100 \mathrm{~g})\end{array}$ & $\mathrm{pH}$ \\
\hline Triceps brachii & 73,31 & 2,31 & 21,03 & 1,82 & 5,47 \\
\hline \hline
\end{tabular}

Os valores de $\mathrm{pH}$ final da carne podem influenciar na maciez, na vida de prateleira do produto e na cor da carne (WATANABE et al., 1996).

Após abate, as reservas de glicogênio são transformadas em ácido lático devido o processo anaeróbico e o acúmulo deste ácido ocasiona a diminuição do pH muscular (LUCHIARI FILHO, 2000). Quando a concentração de glicogênio muscular no momento do abate for insuficiente a queda do pH será comprometida resultando em valores superiores a 6,0, após 24 horas, característica de cortes escuros. Porém se a reserva de glicogênio estiver garantida a queda do $\mathrm{pH}$ será normal resultando em valores de $\mathrm{pH}$ final ao redor de 5,5, após 24 horas, não comprometendo a cor (IMMONEN et al., 2000), um dos principais fatores relacionados a qualidade da carne (FELÍCIO, 2000).

$\mathrm{O}$ pH do músculo Triceps brachii apresentou média de 5,47. Valores de pH final entre 5,4 e 5,8 são considerados normais, ou típicos para a carne bovina (JUDGE et al., 1989; KOOHMARAIE et al., 1991; LUCHIARI FILHO, 2000), valores estes próximos aos encontrados neste experimento. Segundo Immonen et al. (2000) estes valores de $\mathrm{pH}$ final, avaliados 24 horas post-mortem, indicam que não houve comprometimento da qualidade do produto final. 
$\mathrm{Na}$ tabela 4 estão apresentados os valores de $\mathrm{pH}$ em função dos ingredientes utilizados na carne reestruturada crua nos diferentes tempos de armazenamento.

Tabela 4 - Valor do $\mathrm{pH}$ entre os tratamentos nos diferentes tempos de armazenamento

\begin{tabular}{|c|c|c|c|c|}
\hline \multirow{2}{*}{$\begin{array}{c}\text { Tempo } \\
\text { (dias) }\end{array}$} & \multicolumn{4}{|c|}{ Tratamentos } \\
\hline & 1_Controle & 2_Canola & 3_Antioxidante & 4_Canola_Antioxidante \\
\hline 0 & $5,67^{b f} \pm 0,03$ & $5,62^{b f} \pm 0,03$ & $5,55^{b f} \pm 0,03$ & $5,56^{b f} \pm 0,03$ \\
\hline 60 & $5,69^{b f} \pm 0,03$ & $5,57^{b g} \pm 0,03$ & $5,59^{b f g} \pm 0,03$ & $5,51^{\mathrm{bg}} \pm 0,04$ \\
\hline 120 & $5,87^{\text {af }} \pm 0,03$ & $5,94^{a f} \pm 0,03$ & $5,99^{a f} \pm 0,03$ & $5,91^{a f} \pm 0,03$ \\
\hline $\begin{array}{l}a-b \quad \text { Mé } \\
\text { significa } \\
\mathrm{f}-\mathrm{g} \text { Médic } \\
(P>0.05\end{array}$ & $\begin{array}{l}\text { as na mes } \\
\text { lamente }(P>0 \\
\text { na mesma lir }\end{array}$ & $\begin{array}{l}\text { na coluna se } \\
\text { 05). } \\
\text { ha seguidas de }\end{array}$ & guidas de letr & $\begin{array}{l}\text { as iguais não diferem } \\
\text { diferem significativamente }\end{array}$ \\
\hline
\end{tabular}

Ao comparar o $\mathrm{pH}$ da matéria-prima ao da carne reestruturada crua observase que este aumentou, isto porque o tripolifosfato utilizado nas formulações eleva o $\mathrm{pH}$ da carne de 0,2 a 0,5 unidades, tendo em vista a quantidade utilizada e o poder tamponante da carne, o que aumenta a capacidade de retenção de água por meio do deslocamento do ponto isoelétrico das proteínas (BENDALL, 1972). Cestari (2007) relataram valores de $\mathrm{pH}$ mais elevados em carne reestruturada contendo tripolifosfato de sódio. Lee, Hendricks e Cornforth (1998) estudou o efeito do tripolifosfato de sódio sobre as características físico-químicas de carne bovina reestruturada e obteve valor médio de $\mathrm{pH}$ de 5,8, valor este maior quando comparado ao controle.

$\mathrm{Na}$ análise dos resultados da tabela 4 em colunas pode-se observar que para todos os tratamentos houve diferença $(P<0,05)$ em função do tempo de armazenamento, onde aos 120 dias de armazenamento observou-se os maiores valores de $\mathrm{pH}(5,99)$. As pequenas alterações $(\mathrm{P}>0,05)$ no $\mathrm{pH}$ durante os 60 dias de armazenamento a $-18^{\circ} \mathrm{C}$ indicaram que o produto manteve-se estável neste período. De acordo com os dados de $\mathrm{pH}$ de 5,8 a 6,2 sugere-se que a carne apresenta-se aceitável para o consumo, $\mathrm{pH}$ de 6,4 mostra que a carne é 
recomendada apenas para o consumo imediato e $\mathrm{pH}$ acima de 6,4 indica que a carne está em início de decomposição (TERRA; BRUM, 1988). Os bifes reestruturados de carne bovina apresentaram $\mathrm{pH}$ respeitando-se os limites da normalidade até os 120 dias de armazenamento.

Serrano, Cofrades e Jiménez-Colmenero (2006) não observaram efeito do armazenamento congelado sob $\mathrm{o} \mathrm{pH}$ em amostras de bife de carne bovina reestruturada. Porém, Esguerra (1994) relatou que em bife reestruturado bovino houve aumento do $\mathrm{pH}$ com o armazenamento congelado do bife. De forma semelhante, Brewer e Harbers (1991) também observaram o mesmo efeito em carne suína moída congelada.

Os resultados encontrados neste estudo também são similares aos encontrados por Pellegrini et al. (2012) que estudaram o efeito do tempo de armazenamento sob as características físico-químicas da carne ovina e verificaram comportamento linear crescente para os valores de $\mathrm{pH}$, sendo que para cada dia de estocagem o valor de $\mathrm{pH}$ elevou-se em 0,0006\%.

De acordo com Allen, Russell e Fletcher (1997), há uma correlação positiva entre $\mathrm{pH}$ e armazenamento, indicando um aumento do $\mathrm{pH}$ em filés de peito de frangos com o armazenamento, assim como relatado por Yang e Chen (1993).

$O$ tipo de tratamento influenciou $(\mathrm{P}<0,05) \circ \mathrm{pH}$ somente aos 60 dias de armazenamento, em que o tratamento com óleo de canola apresentou menores valores $(5,57)$. Segundo Serrano, Cofrades e Jiménez-Colmenero (2006) a adição de óleo de nozes causou aumento nos valores de $\mathrm{pH}$ das amostras de bifes reestruturados crus e cozidos.

Tabela 5 - Médias e erros-padrão dos resultados das análises físico-químicas da carne reestruturada crua.

\begin{tabular}{llccc}
\hline \hline \multicolumn{1}{c}{ Tratamento } & $\begin{array}{c}\text { Umidade } \\
(\mathrm{g} / 100 \mathrm{~g})\end{array}$ & $\begin{array}{c}\text { Lipídios } \\
(\mathrm{g} / 100 \mathrm{~g})\end{array}$ & $\begin{array}{c}\text { Proteínas } \\
(\mathrm{g} / 100 \mathrm{~g})\end{array}$ & $\begin{array}{c}\text { Cinzas } \\
(\mathrm{g} / 100 \mathrm{~g})\end{array}$ \\
\hline \hline 1_Controle & $68,43^{\mathrm{bc}} \pm 0,83$ & $10,42^{\mathrm{b}} \pm 0,6$ & $15,65^{\mathrm{a}} \pm 0,23$ & $2,71^{\mathrm{a}} \pm 0,04$ \\
2_Canola & $62,88^{\mathrm{a}} \pm 0,83$ & $13,05^{\mathrm{a}} \pm 0,6$ & $14,32^{\mathrm{b}} \pm 0,23$ & $2,68^{\mathrm{a}} \pm 0,04$ \\
3_Antioxidante & $69,31^{\mathrm{c}} \pm 0,83$ & $9,89^{\mathrm{b}} \pm 0,6$ & $15,74^{\mathrm{a}} \pm 0,23$ & $2,77^{\mathrm{a}} \pm 0,04$ \\
4_Canola_Antioxidante & $65,04^{\mathrm{ab}} \pm 0,83$ & $13,98^{\mathrm{a}} \pm 0,6$ & $14,48^{\mathrm{b}} \pm 0,23$ & $2,74^{\mathrm{a}} \pm 0,04$ \\
\hline abc Médias na mesma coluna seguidas de letras iguais & não diferem \\
significativamente $(\mathrm{P}>0,05)$.
\end{tabular}


A adição de óleo de canola afetou a composição centesimal dos bifes reestruturados (Tabela 5). A adição de óleo de canola aumentou $(P<0,05)$ os valores de gordura e reduziu $(P<0,05)$ os valores de umidade (na mesma proporção em que a gordura foi aumentada) e teor de proteína. $O$ teor de cinzas não foi influenciado $(P>0,05)$ pela adição de óleo de canola. Os mesmos resultados foram encontrados por Serrano, Cofrades e Jiménez-Colmenero (2006) e Serrano et al. (2007). A composição centesimal das amostras de carne reestruturada foi consistente com as formulações utilizadas na elaboração dos produtos cárneos reestruturados neste estudo, onde a carne foi substituída pelo adição de óleo (Tabela 1).

\subsection{PERDAS DE PESO}

As perdas durante o descongelamento no presente estudo foram inferiores a $1 \% \quad(P>0,05)$. Independentemente da sua composição, bifes reestruturados apresentaram baixos teores de perda ao descongelamento $(<1 \%)$, semelhantes resultados foram encontrados por outros autores para produtos similares (RAHARJO et al., 1995; JIMÉNEZ COLMENERO et al., 2003; SERRANO; COFRADES; JIMÉNEZ-COLMENERO, 2006; SERRANO et al., 2007; CESTARI, 2007).

As perdas durante 0 descongelamento e cocção afetam o custo de fabricação de carne reestruturada. O controle dessas perdas é importante devido às mudanças nos resultados de rendimento de cocção por afetar a composição centesimal do produto, e essas mudanças estão diretamente correlacionadas às características sensoriais do produto final grelhado. A umidade é perdida durante e após o processo térmico, com isto o rendimento do produto e outros atributos de qualidade como maciez, textura, e sabor, são afetados negativamente (PIETRASIK, 2003).

Em relação a perdas por cocção, houve influencia dos tratamentos e tempo de armazenamento $(P<0,05)$ sobre esta característica avaliada. 
Tabela 6 - Médias e erros-padrão dos resultados de perdas por cocção da carne reestruturada

\begin{tabular}{|c|c|}
\hline & Perdas Cozimento (\%) \\
\hline \multicolumn{2}{|l|}{ Tratamentos } \\
\hline 1_Controle & $21,45^{\mathrm{ab}} \pm 1,42$ \\
\hline 2 Canola & $18,54^{\mathrm{ab}} \pm 1,48$ \\
\hline 3_Antioxidante & $16,34^{b} \pm 1,42$ \\
\hline 4_Canola_Antioxidante & $23,66^{a} \pm 1,54$ \\
\hline \multicolumn{2}{|l|}{ Tempos (dias) } \\
\hline 0 & $13,44^{b} \pm 1,24$ \\
\hline 60 & $24,35^{a} \pm 1,43$ \\
\hline 120 & $22,21^{a} \pm 1,11$ \\
\hline Interações & Ns \\
\hline
\end{tabular}

Em relação ao tipo de tratamento, a maior perda foi verificada nos bifes reestruturados, formulados com antioxidante mais canola $(23,66 \%)$, diferindo $(P<0,05)$ do bife reestruturado somente com antioxidante, o qual apresentou menores perdas $(16,34 \%)$, porém não deferiram dos tratamentos controle e com óleo de canola. Houve diferença $(P<0,05)$ entre o tempo de armazenamento, sendo que o tempo 0 resultou em menor perda (13,44\%) e o tempo 60 e 120 dias não diferiram entre si, apresentando as maiores perdas de cocção $(24,35 \%$ e $22,21 \%$, respectivamente).

Os valores médios para perda de cocção apresentados na tabela 6 foram inferiores àqueles observados na literatura, que variam entre 31\% a 35\% (LENNON et al., 2006), demonstrando que o teor de $1 \%$ de transglutaminase foi efetivo em ligar a água do produto.

Carne reestruturada com sal, tripolifosfato e diferentes ligantes apresentam perdas de cocção muito variáveis de acordo com a literatura. No trabalho de Raharjo et al. (1995) o tratamento com $0,5 \% \mathrm{NaCl}$ e $0,5 \%$ STPP apresentou perdas entre $30-34 \%$, quando utilizaram $0,5 \% \mathrm{Na}$-alginato e $0,5 \% \mathrm{Ca}$-lactato as perdas variaram de $25-33 \%$. Já Shao et al. (1999), com teores de $1,5 \% \mathrm{NaCl}$ e $0.5 \%$ STPP obtiveram perdas de cocção em torno de $20 \%$, enquanto Colmenero et al. (2003) em reestruturados contendo $0,5 \% \mathrm{NaCl}$ e $0,5 \%$ STPP, entre $19 \%$ (no tratamento com $2 \% \mathrm{NaCl}$ ) e $27 \%$ (no tratamento com $1 \% \mathrm{NaCl}$ ). 
Segundo Lee, Hendricks e Cornforth (1998), carnes tratadas com tripolifosfato de sódio possuem superior força de ligação, rendimento de cocção e umidade.

Youssef e Barbut (2009) testaram a substituição da gordura bovina por óleo de canola em produto cárneo com 14 a 15\% de proteína e obtiveram maiores perdas de gordura no cozimento do produto com óleo de canola, provavelmente devido às diferentes características físicas deste óleo. Já os mesmos autores posteriormente, Youssef e Barbut (2011), relataram que a perda de cocção é inversamente relacionada com o teor em gordura, obtendo maiores perdas de cocção no tratamento controle, em comparação com emulsões à base de carne preparada com óleo de canola. Por outro lado, Townsend et al. (1971) relataram que salsichas preparadas com óleo vegetal apresentaram maior perda de cocção, em relação àqueles produtos preparados com gordura animal. Paneras e Bloukas (1994) relataram que a substituição de gordura suína com óleo não teve nenhum efeito sobre o rendimento de cozimento em salsichas com baixo teor de gordura preparados com $12,5 \%$ de proteína.

Segundo Serrano, Cofrades e Jiménez-Colmenero (2006) as perdas de cocção diminuíram à medida que a proporção de nozes aumentou em reestruturados bovinos, sendo mais altas para amostra controle (34\%). Este comportamento, já relatado (JIMÉNEZ-COLMENERO et al., 2003; COFRADES et al., 2004), pode estar relacionado com a perda de humidade (e aumento do teor de gordura) e diluição da proteína da carne em produtos com mais nozes adicionado.

No presente estudo, nos tratamentos sem óleo de canola o nível de proteína mais elevado parece ter ajudado a estabilizar o produto, ocorrendo uma menor perda de cocção. Isto pode ter sido devido à presença de algumas células ininterrupta de gordura, o que permitiu outras proteínas musculares reterem a água e proporcionou maior imobilização de gordura (SCHUT, 1978). Outra explicação também poderia ser dada para maior perda de exsudado na cocção dos bifes com adição de óleo de canola, devido a mobilidade do óleo durante o aquecimento, resultando em maior pressão interna dentro dos glóbulos de gordura da carne, e esta pressão superou a resistência do filme de proteína, causando mais possibilidades para à ruptura do filme protéico a fim de expandir durante o processo de aquecimento. De acordo, com os resultados obtidos por Lee, Carroll e Ardollahi (1981), que descobriram que a mobilidade de gordura é inversamente relacionada 
com a dureza de gordura e aumenta à medida que a gordura amolece; atingindo um máximo a $0 \%$ de conteúdo de gordura sólida.

Stika et al. (2007) observaram que a formulação de bifes reestruturados com a utilização de agente saborizante reduziu a perda de cocção, enquanto que somente a adição do antioxidante propil galato não resultou em efeito no processo. Os mesmos autores observaram que o tempo de armazenamento tem efeito sobre a perda de cocção, onde durante o primeiro mês de armazenamento não houve alteração, contudo houve aumento após 3 e 6 meses. Chastain et al. (1982) também relataram que o rendimento de cozimento de carne suína reestruturada foi reduzdo conforme o armazenamento congelado progrediu ao longo de 20 semanas. Isto implicou na ruptura física da estrutura celular ou possível desnaturação de proteínas durante o armazenamento congelado. Em contraste, Reverte, Xiong e Moody (2003) relataram que o rendimento de cozimento de bifes reestruturados de carne bovina não foi alterado durante 6 meses de estocagem.

$O$ efeito do armazenamento congelado sobre a perda na cocção (e sobre outras propriedades físico-químicas) depende das características dos produtos e condições de armazenamento. Muitos autores relataram maiores perdas de cocção em produtos cárneos congelados com aumento do tempo de armazenamento congelado (JACOBS; SEBRANEK, 1980; BHATTACHARYA; HANNA; MANDIGO, 1988a; MCMILLIN et al., 1991). Já Serrano, Cofrades e Jiménez-Colmenero (2006) observaram que o armazenamento congelado não afetou a perda de cocção de produtos reestruturados.

\subsection{DETERMINAÇÃO DA OXIDAÇÃO LIPÍDICA}

Houve interação $(P<0,05)$ entre os tratamentos, em função do tempo de armazenamento para valores de TBARS (Tabela 7).

A oxidação lipídica é uma das principais causas da deterioração da qualidade especialmente de produtos cárneos armazenados e podem ser acelerados por vários fatores, tais como aumento da insaturação, presença de oxigénio (favorecida por desintegração estrutural), sal, etc. As mudanças na qualidade são manifestadas por mudanças desfavoráveis no sabor, cor, textura e 
valor nutritivo, e possível produção de compostos tóxicos. A ruptura da integridade da membrana muscular por mecanismos como corte e mistura, alteram a compartimentalização celular, facilitando a interação de agentes pró-oxidantes com ácidos graxos insaturados, resultando na geração de ácidos graxos livres e a propagação de reações oxidativas (GRAY; GOMAA; BUCKLEY, 1996). Alterações na composição induzidas pela adição de óleo de canola e eritorbato de sódio podem afetar a sensibilidade de produtos cárneos à oxidação lipídica.

Tabela 7. Médias e erros-padrão dos resultados do valor TBARS (mg malonaldeído/ $\mathrm{kg}$ de amostra) da carne reestruturada

\begin{tabular}{ccccc}
\hline \multirow{2}{*}{$\begin{array}{c}\text { Tempo } \\
\text { (dias) }\end{array}$} & 1_Controle & 2_Canola & $\begin{array}{c}\text { 3_Antioxidant } \\
\text { e }\end{array}$ & $\begin{array}{c}\text { 4_Canola_ } \\
\text { Antioxidante }\end{array}$ \\
\hline \hline $\mathbf{0}$ & $0,044^{\mathrm{cf}} \pm 0,2$ & $0,087^{\mathrm{df}} \pm 0,2$ & $0,060^{\mathrm{bf}} \pm 0,2$ & $0,094^{\mathrm{bf}} \pm 0,2$ \\
$\mathbf{3 0}$ & $0,059^{\mathrm{cf}} \pm 0,2$ & $0,053^{\mathrm{df}} \pm 0,2$ & $0,049^{\mathrm{bf}} \pm 0,2$ & $0,076^{\mathrm{bf}} \pm 0,2$ \\
$\mathbf{6 0}$ & $4,517^{\mathrm{bf}} \pm 0,2$ & $4,104^{\mathrm{af}} \pm 0,2$ & $0,680^{\mathrm{ag}} \pm 0,2$ & $0,838^{\mathrm{ag}} \pm 0,2$ \\
$\mathbf{9 0}$ & $5,587^{\mathrm{af}} \pm 0,2$ & $2,992^{\mathrm{b} \mathrm{g}} \pm 0,2$ & $1,056^{\mathrm{ah}} \pm 0,2$ & $1,053^{\text {a h }} \pm 0,2$ \\
$\mathbf{1 2 0}$ & $4,838^{\mathrm{bf}} \pm 0,2$ & $2,387^{\mathrm{c} \mathrm{g}} \pm 0,2$ & $0,946^{\text {a h }} \pm 0,2$ & $1,066^{\text {a h }} \pm 0,2$
\end{tabular}

${ }^{a-\bar{d} \text { Médias na mesma coluna seguidas de letras iguais não diferem }}$ significativamente $(P>0,05)$.

$\mathrm{f}$-h Médias na mesma linha seguidas de letras iguais não diferem significativamente $(P>0,05)$.

Ao analisar os resultados da tabela $7 \mathrm{em}$ linhas pode-se observar que para os tempos 0 e 30 dias não houve diferença $(P>0,05)$ entre os tratamentos. Já para os tempos 60, 90 e 120 dias, houve diferença $(P<0,05)$ entre os tratamentos, onde na ausência do antioxidante tiveram resultados maiores para TBARS, indicando que a adição do antioxidante eritorbato de sódio retardou efetivamente a oxidação lipídica nos bifes reestruturados. O tratamento com canola (2) também diferiu do tratamento controle (1) nos tempos de 90 e 120 dias, onde o tratamento com canola apresentou menores valores de TBARS, sugerindo que o óleo de canola apresentou efeito antioxidante. 
Os resultados analisados em colunas demonstram que a oxidação lipídica aumentou conforme progrediu o período de congelado em todos os tratamentos. Observando-se um aumento significativo $(P>0,05)$ aos 60 dias de armazenamento. Resultados similares foram encontrados por diversos autores, que concluíram que os valores de TBARS da carne reestruturada congelada aumentam durante longos períodos de armazenamento (LAMKEY; MANDIGO; CALKINS, 1986; AKAMITTATH; BREKKE; SCHANUS, 1990; REVERTE; XIONG; MOODY, 2003).

$O$ efeito do antioxidante explica a interação significativa $(P<0,05)$ entre tratamento $\mathrm{x}$ tempo de armazenamento em bifes reestruturados (STIKA et al., 2007). Reverte, Xiong e Moody (2003) observaram efeito antioxidante similar utilizando propil galato em carne de novilhos.

O gráfico que representa essa interação para o valor TBARS consta da figura 8.

Figura 8. Interação tratamento $x$ tempo de armazenamento em função do TBARS da carne reestruturada crua

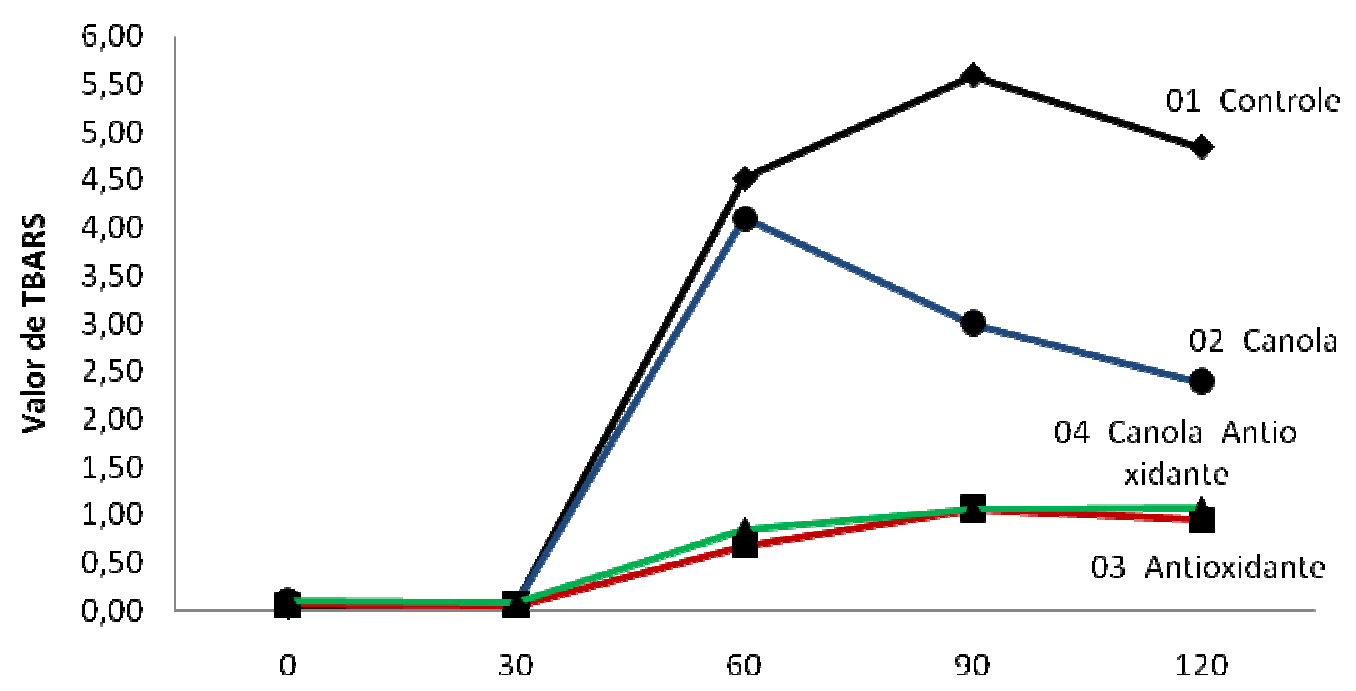

Antioxidantes fenólicos sintéticos como eliminadores de radicais livres têm sido usados para controlar as reações de oxidação de lipídios nos alimentos (CHASTAIN et al., 1982). Os metais de transição tais como o ferro e o cobre e a porção heme desempenham um papel importante na peroxidação da membrana de ácidos graxos poliinsaturados de alimentos musculares (KELLER; KINSELLA, 1973). O fosfato exerce efeito antioxidante devido à sua capacidade para quelar os 
íons metálicos pró-oxidativos (LAMKEY; MANDIGO; CALKINS, 1986; ARGANOSA et al., 1991). Esta ação do fosfato pode estar envolvida na inibição da peroxidação lipídica em carne crua e cozida, resultando em menor formação de TBARS. A carne vermelha possui alto teor de ferro e de gordura, podendo proporcionar substratos para a peroxidação lipídica (SOUCI, FACHMANN, KRAUT, 1989). Os produtos da peroxidação podem também ser mutagênico e carcinogênico (JANERO, 1990; HALLIWELL; CHIRICO, 1993). No presente estudo, a adição de tripolifosfato de 0,3\% em todas as amostras foi aparentemente incapaz de inibir a oxidação de lípidos após 60 dias de armazenamento. Akamittath, Brekke e Schanus (1990) relataram que o efeito pró-oxidativo do sal e de outras substâncias, tais como peróxido metamioglobina ativado presente no músculo bovino, superaram o efeito protetor do tripolifosfato em bifes ao longo de períodos de armazenamento prolongados.

De acordo com os resultados do presente estudo, sugere-se que os bifes reestruturados formulados exclusivamente com carne bovina com ou sem adição de óleo de canola e armazenado congelado durante mais de 60 dias devem conter antioxidantes, além da adição de tripolifosfato, para minimizar a oxidação de lípidios e neutralizar o efeito pró-oxidante do sal adicionado.

McCarthy et al. (2001) estudaram o uso de vários antioxidantes em carne suína e concluíram que o antioxidante mais efetivo contra a oxidação lipídica foi a catequina oriunda do chá, um antioxidante natural.

Serrano, Cofrades e Jiménez-Colmenero (2006) testaram diferentes níveis de nozes em bifes reestruturados e observou que a oxidação lipídica foi maior em bifes reestruturados com adição de nozes do que nas amostras controle, um efeito que pode ter sido relacionado com o teor de gordura das nozes. Resultados semelhantes foram encontrados por Serrano et al. (2007), que concluíram que as nozes contêm grandes quantidades de ácidos graxos insaturados (KRISETHERTON, 1999; NUS; RUPERTO; SÁNCHEZ-MUNIZ, 2004) que são suscetíveis à oxidação.

Rhee et al. (1988) estudaram a utilização de 10 a $20 \%$ de óleo de canola na alimentação de bovinos sobre a oxidação lipídica do músculo, os resultados obtidos embora não tenham sido diferentes entre os tratamentos, indicam uma tendência a maiores valores de TBARS para os músculos de animais alimentados com 10 a $20 \%$ de óleo de canola. Os autores explicam que essa tendência pode ser devido 
as maiores porcentagens de ácidos graxos poliinsaturados presentes nas dietas dos animais.

Kim, Godber e Prinaywiwatkul (2000) elaboraram e avaliaram bolos de carne reestruturados contendo fibra de arroz e óleo de arroz. Os autores constataram que os bolos com fibra de arroz ou com óleo do arroz apresentaram estabilidade oxidativa maior durante o armazenamento do que os bolos de carne sem esses componentes.

O quelante e a atividade de tamponamento do fitato e fosfato podem também contribuir para a estabilidade da cor da carne crua reestruturada porque a oxidação da mioglobina é conhecida por ser acelerada pela presença de radicais livres ou pela carne com baixo pH (GRAY; GOMAA; BUCKLEY, 1996).

Alguns autores propuseram uma relação inversa entre a oxidação lipídica e estabilidade da cor em carnes reestruturadas durante o armazenamento congelado (AKAMITTATH; BREKKE; SCHANUS, 1990). Essas alterações foram observadas no presente estudo onde ambos os fenômenos parecem indicar que a degradação da cor e oxidação de lipídios estão relacionadas.

\subsection{DETERMINAÇÃO DO COLESTEROL}

Nos dias atuais existe uma grande preocupação com os teores de gordura e/ou colesterol em carne e produtos cárneos, isto pode ser observado pelas diversas pesquisas citadas no presente estudo com o intuito de produzir alimentos com baixos teores de gordura.

O colesterol pertence ao grupo de lipídios e está presente predominantemente no reino animal. Na carne utilizada para a formulação do reestruturado, miolo da paleta, o teor de colesterol na literatura de cortes bovinos encontrados foi entre 45 a $62 \mathrm{mg} / 100 \mathrm{~g}$ (BRAGAGNOLO; RODRIGUEZ-AMAYA, 1995; COSTA et al., 2002). 
Tabela 8 - Médias e erros-padrão dos resultados de teor de colesterol $(\mathrm{mg} / 100 \mathrm{~g})$ da carne reestruturada

\begin{tabular}{lc}
\hline Tratamentos & $\begin{array}{c}\text { Teor de Colesterol } \\
(\mathbf{m g} / \mathbf{1 0 0 g})\end{array}$ \\
\hline \hline 1_Controle & $47,21^{\mathrm{bc}} \pm 0,85$ \\
2_Canola & $50,44^{\mathrm{ab}} \pm 0,85$ \\
3_Antioxidante & $53,97^{\mathrm{a}} \pm 0,85$ \\
4_Canola_Antixidante & $46,36^{\mathrm{c}} \pm 0,85$
\end{tabular}

a-c Médias na mesma coluna seguidas de letras iguais não diferem significativamente $(P>0,05)$.

A adição do óleo de canola e do antioxidante afetou significativamente $(P<0,05)$ o teor de colesterol na carne reestruturada crua. A adição do eritorbato de sódio mais $5 \%$ de óleo de canola (4) resultou em carnes com um teor de colesterol ligeiramente reduzido $(46,36 \mathrm{mg} / 100 \mathrm{~g})$, quando comparada com o tratamento contendo apenas antioxidante $(53,97 \mathrm{mg} / 100 \mathrm{~g})$. Os resultados encontrados ficaram próximos aos valores da carne bovina crua (45 a $62 \mathrm{mg} / 100 \mathrm{~g}$ ).

Estes resultados indicam que é possível melhorar o valor nutricional da carne bovina reestruturada, com a adição de óleo de canola, devido a presença de ácidos graxos poliinsaturados (PUFA). Por outro lado, a oxidação do colesterol é altamente influenciada pela composição de ácidos graxos, principalmente dos ácidos graxos insaturados. Os tecidos com maiores teores de PUFA promoveriam uma maior taxa de formação de radicais livres, acelerando a oxidação do colesterol (MARASCHIELLO; ESTEVE; GARCÍA-REGUEIRO, 1998; GALVIN; MORRISEY; BUCKLEY, 1998; ECHARTE; ANSORENA; ASTIASARÁN, 2003) e formação de óxidos de colesterol, que estão relacionados com a formação da aterosclerose, além de serem mutagênicos e cancerígenos (PEARSON et al. 1983; KUBOW, 1993). Este fato foi confirmado pelo menor teor de colesterol em (4) em comparação com (3) que, provavelmente, diminuiu devido à oxidação do colesterol.

No presente estudo, os teores de colesterol apresentaram valores aceitáveis (46,36 - 53,97mg de colesterol) visto que Ramires (2009) recomendou uma ingestão diária de $180 \mathrm{mg}$ de colesterol e a título de comparação com relação a outros produtos cárneos industrializados, observou-se que a lingüiça suína comercial grelhada apresentou $82 \mathrm{mg} / 100 \mathrm{~g}$ enquanto que o hambúrguer grelhado apresentou $59 \mathrm{mg} / 100 \mathrm{~g}$ de colesterol (UNIVERSIDADE DE CAMPINAS - 
UNICAMP, 2006).

\subsection{ANÁLISE MICROBIOLÓGICA}

Os resultados encontrados nas análises microbiológicas para matéria-prima e carne reestruturada no início do experimento ( 0 dias) e no final do armazenamento (120 dias) estão apresentados na tabela 9.

Tabela 9 - Resultados das análises microbiológicas da matéria-prima e carne reestruturada crua com 0 e 120 dias, em comparação aos limites da legislação

\begin{tabular}{|c|c|c|c|c|c|}
\hline Tratamento & $\begin{array}{c}\text { Tempo } \\
\text { (dias) }\end{array}$ & $\begin{array}{l}\text { Salmonella } \\
\text { SSP em } \\
25 \mathrm{~g}\end{array}$ & $\begin{array}{c}\text { Staphylococcus } \\
\text { aureus } \\
\text { coagulase } \\
\text { positiva } \\
\text { (UFC/g) }\end{array}$ & $\begin{array}{l}\text { Clostridium } \\
\text { Sulfito } \\
\text { Redutores } \\
\text { (UFC/g) }\end{array}$ & $\begin{array}{c}\text { Coliformes } \\
\text { Termotolerantes } \\
\text { (UFC/g) }\end{array}$ \\
\hline Limites Legislação & - & Ausência & $5 \times 10^{3}$ & $3 \times 10^{3}$ & $5 \times 10^{3}$ \\
\hline \multirow{2}{*}{ 1_Controle } & 0 & Ausência & $<1,0 \times 10^{1}$ & $<1,0 \times 10^{1}$ & $<1,0 \times 10^{1}$ \\
\hline & 120 & Ausência & $<1,0 \times 10^{1}$ & $<1,0 \times 10^{1}$ & $<1,0 \times 10^{1}$ \\
\hline \multirow{2}{*}{ 2_Canola } & 0 & Ausência & $<1,0 \times 10^{1}$ & $<1,0 \times 10^{1}$ & $<1,0 \times 10^{1}$ \\
\hline & 120 & Ausência & $<1,0 \times 10^{1}$ & $<1,0 \times 10^{1}$ & $<1,0 \times 10^{1}$ \\
\hline \multirow{2}{*}{ 3_Antioxidante } & 0 & Ausência & $<1,0 \times 10^{1}$ & $<1,0 \times 10^{1}$ & $<1,0 \times 10^{1}$ \\
\hline & 120 & Ausência & $<1,0 \times 10^{1}$ & $<1,0 \times 10^{1}$ & $<1,0 \times 10^{1}$ \\
\hline \multirow{2}{*}{ 4_Canola_Antioxidante } & 0 & Ausência & $<1,0 \times 10^{1}$ & $<1,0 \times 10^{1}$ & $<1,0 \times 10^{1}$ \\
\hline & 120 & Ausência & $<1,0 \times 10^{1}$ & $<1,0 \times 10^{1}$ & $<1,0 \times 10^{1}$ \\
\hline Matéria-prima & 0 & Ausência & $<1,0 \times 10^{1}$ & $<1,0 \times 10^{1}$ & $<1,0 \times 10^{1}$ \\
\hline
\end{tabular}

Os resultados apresentados na tabela 9 estão de acordo com os padrões exigidos pela legislação. Portanto, as amostras de bifes reestruturados foram consideradas adequadas para o consumo.

É importante destacar que somente após a verificação dos resultados referente a microbiologia das amostras é que procedeu-se a avaliação sensorial. 
A avaliação da cor foi realizada para detectar tendências a mudanças nos bifes causadas pela adição de óleo de canola e o armazenamento congelado. A cor da carne é um dos principais fatores pelo qual os consumidores julgam a sua aceitabilidade. A descoloração de produtos cárneos é um grande problema para a comercialização de produtos reestruturados de carne, uma vez que reduz a aceitabilidade do consumidor (CHEN; TROUT, 1991).

Não houve efeito $(P>0,05)$ de interação dos fatores (tratamento $X$ tempo de armazenamento) em relação aos parâmetros de cor avaliados, luminosidade $\left(\mathrm{L}^{*}\right)$, intensidade de amarelo $\left(b^{*}\right)$ e intensidade de vermelho $\left(a^{*}\right)$, descritos na tabela 10

Tabela 10 - Médias e erros-padrão dos resultados do perfil colorimétrico instrumental da carne reestruturada de acordo com os tratamentos

\begin{tabular}{|c|c|c|c|}
\hline & $\mathrm{L}^{*}$ & $\mathbf{a}^{*}$ & $\mathbf{b}^{*}$ \\
\hline \multicolumn{4}{|l|}{ Tratamento } \\
\hline 1_Controle & $25,76^{\mathrm{b}} \pm 1,42$ & $17,70^{a} \pm 1,23$ & $14,98^{b} \pm 0,66$ \\
\hline 2_Canola & $37,60^{a} \pm 1,35$ & $14,99^{a} \pm 1,17$ & $19,70^{a} \pm 0,63$ \\
\hline 3_Antioxidante & $26,06^{b} \pm 1,42$ & $19,68^{a} \pm 1,23$ & $15,92^{b} \pm 0,66$ \\
\hline 4_Canola_Antixidante & $33,65^{a} \pm 1,42$ & $18,35^{a} \pm 1,23$ & $18,59^{a} \pm 0,66$ \\
\hline \multicolumn{4}{|l|}{ Tempo (dias) } \\
\hline 0 & $36,30^{a} \pm 1,28$ & $15,47^{a} \pm 1,11$ & $20,88^{a} \pm 0,59$ \\
\hline 60 & $28,38^{b} \pm 1,32$ & $19,09^{a} \pm 1,15$ & $16,22^{b} \pm 0,61$ \\
\hline 120 & $27,62^{b} \pm 1,02$ & $18,48^{a} \pm 0,89$ & $14,79^{b} \pm 0,48$ \\
\hline Interações & Ns & ns & Ns \\
\hline \multicolumn{4}{|c|}{$\begin{array}{l}\text { Médias na mesma coluna seguidas de letras iguais não } \\
\text { significativamente }(P>0,05) ; n \text { ns: não significativa. }\end{array}$} \\
\hline
\end{tabular}

Os valores de luminosidade $\left(L^{*}\right)$ e intensidade de amarelo $\left(b^{*}\right)$ foram diferentes $(P<0,05)$ entre os tratamentos (Tabela 10). A carne reestruturada com adição de óleo de canola (tratamentos 2 e 4) apresentaram os maiores valores de $L^{*}(37,60$ e 33,65$)$ e $b^{*}(19,70$ e 18,59) e diferentes $(P<0,05)$ da carne reestruturada 
sem óleo de canola (tratamentos 1 e 3 ) que resultaram em menores valores de $L^{*}$ $(25,76$ e 26,06$)$ e $b^{*}(14,98$ e 15,92). No presente estudo, o aumento da luminosidade (croma $L^{*}$ ) nos produtos reestruturados com adição de óleo de canola, provavelmente está relacionado com o fato de os glóbulos de gordura do óleo de canola serem muito menores e assim refletirem mais luz (área de superfície maior) em comparação aos glóbulos de gordura bovina que são maiores. A tonalidade mais acentuada de $\mathrm{b}^{*}$ das carnes reestruturadas com óleo de canola provavelmente foi devido à cor mais amarelada do óleo de canola.

Não houve diferenças $(P>0,05)$ na avaliação da intensidade de vermelho e os resultados variaram entre 14,99 a 19,68. De acordo com os dados da literatura a intensidade do vermelho para o músculo Triceps brachii variam de 16,6 a 20,0 (LENNON et al., 2006), o que está de acordo com os resultados deste experimento, exceto para o tratamento 2, contendo somente óleo de canola. Lennon et al. (2006) compararam a cor da carne reestruturada com o músculo íntegro e relataram que não houve diferenças entre eles.

Os resultados encontrados neste experimento encontram-se semelhantes àqueles verificados por Youssef e Barbut (2009) que utilizaram $25 \%$ de óleo de canola na elaboração de produtos cárneos bovinos em comparação com a utilização de $25 \%$ de gordura bovina e obtiveram valores de $b^{*}$ mais altos para os tratamentos com óleo de canola $(14,81)$ em relação ao com gordura bovina $(13,68)$.

Serrano, Cofrades e Jiménez-Colmenero (2006) verificaram resultados semelhantes ao testar diferentes níveis de nozes em reestruturados bovinos, onde o tratamento contendo nozes aumentou a luminosidade e o amarelecimento, porém diminuiu o vermelhidão, fato que não foi observado no presente trabalho. Resultados semelhantes foram relatados por Jiménez Colmenero et al. (2003).

Youssef e Barbut (2011), ao substituir a gordura da carne com óleo de canola ou óleo de canola pré-emulsionado, obteve aumento na luminosidade em todos os níveis de gordura em comparação com o controle, onde os valores de luminosidade aumentaram com o aumento do teor de óleo de canola. No entanto, Paneras e Bloukas (1998) indicaram que salsichas com elevados teor de gordura foram mais escuras do que produtos com baixo teor de gordura produzidos com diferentes níveis de óleos vegetais.

$O$ efeito do tempo de armazenamento influenciou $(P<0,05)$ os cromas $L^{*}$ e $b^{*}$ (Tabela 10). $O$ tempo provocou uma redução $(P<0,05)$ dos valores de $L^{*}$ e $b^{*}$ 
(Figuras 9 e 10) na carne reestruturada aos $60(28,38$ e 16,22) e $120(27,62$ e 14,79) dias de armazenamento comparados ao $0(36,60$ e 20,88) dia de armazenamento. Estes resultados indicam que houve um escurecimento (menor valor de $L^{*}$ ) e redução da intensidade de coloração amarela (menor valor de $b^{*}$ ) ao longo da estocagem para todos os tratamentos.

Figura 9. Valores de $L^{*}$ do músculo triceps brachii em função do tempo de armazenamento

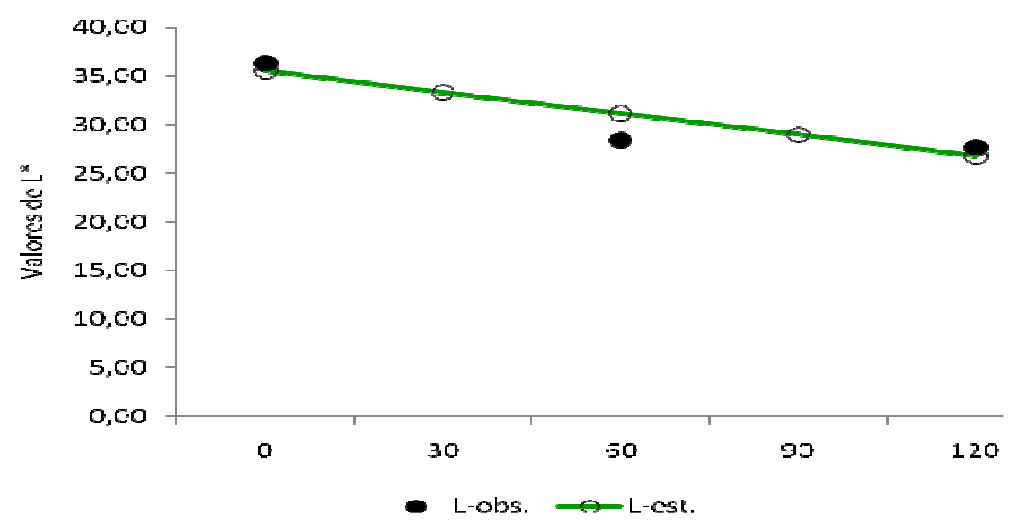

Figura 10. Valores de $b^{*}$ do músculo triceps brachii em função do tempo de armazenamento

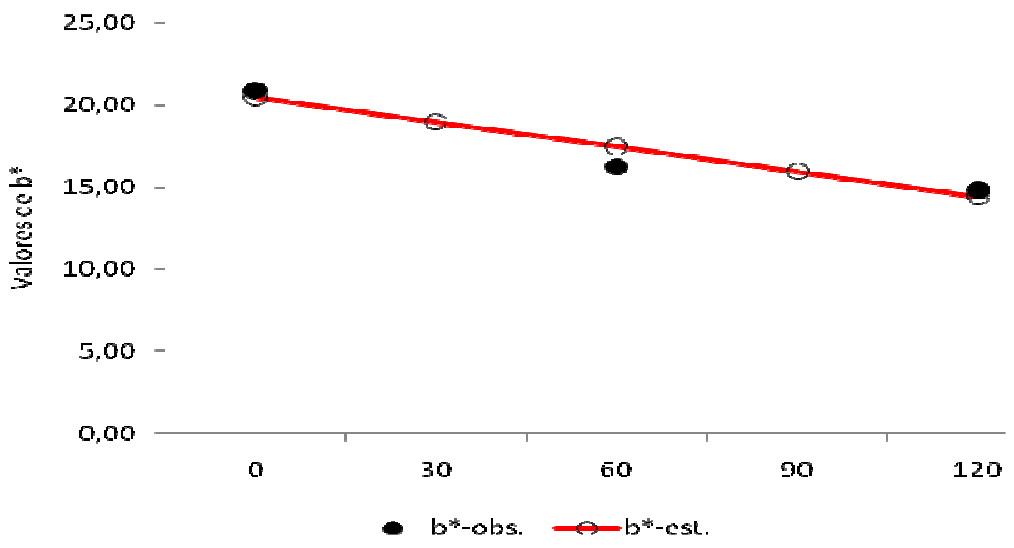

Uma vez que não houve interação $(P>0,05)$ entre os tratamentos e o tempo de armazenamento, concluiu-se que o antioxidante eritorbato de sódio foi ineficaz em retardar a oxidação do pigmento heme, isto é, a conversão de ferro ferroso para ferro férrico do complexo heme.

Segundo Serrano, Cofrades e Jiménez-Colmenero (2006) o processo de armazenamento congelado de bifes reestruturados não influenciou os parâmetros 
$L^{*}$ e $b^{*}$, mas afetou os valores de $a^{*}$, que foram reduzidos durante 0 armazenamento.

Stika et al. (2007) estudaram o efeito do antioxidante propil galato sobre o armazenamento congelado de reestruturado bovino e os autores relataram que a

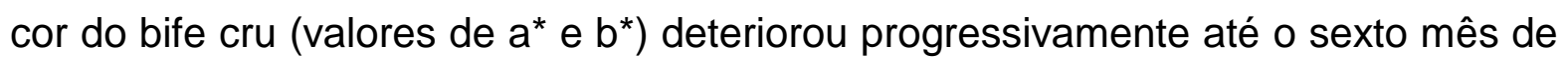
armazenamento.

Huffman et al. (1984) indicaram que a adição de sal em produtos reestruturado bovinos aumentou a descoloração da carne crua, e sugeriram que a adição de sal pode agir como um pró-oxidante, interagindo com o heme e reduzindo o pH do produto cárneo. Como demonstrado por Seideman et al. (1984), o sal pode também atuar como um pró-oxidantes e promover a oxidação do pigmento, reduzindo a tensão de oxigénio e diminuindo a capacidade de tamponamento da carne, aumentando assim o potencial para a oxidação de mioglobina.

Reverte, Xiong e Moody (2003) também estudaram o efeito da adição de propil galato em bifes reestruturados bovinos que observaram que 0 valor de $L^{*}$ (32) não foi afetado nem pela adição do antioxidante e nem pelo tempo de armazenamento. Da mesma forma, os valores de $a^{*} e b^{*}$ não foram influenciados pelo tratamento contendo antioxidante. No tentanto, os valores de $a^{*} \mathrm{e} b^{*}$ foram reduzidos após 3 ou 6 meses em todas as amostras, indicando que a descoloração ocorreu em bifes reestruturados.

McCarthy et al. (2001) estudaram o uso dos antioxidantes hidroxianosil butilato (BHA) e hidroxitolueno butilato $(\mathrm{BHT})$ em carne suína e estes foram muito eficazes na preservação da cor vermelha.

\subsection{ANÁLISE INSTRUMENTAL DE TEXTURA}

\subsubsection{ANÁLISE DE PERFIL DE TEXTURA}

A textura da carne reestruturada foi avaliada por meio da técnica denominada análise do perfil de textura ou TPA, onde foram calculados os 
parâmetros de dureza, elasticidade, coesividade, e mastigabilidade. Os resultados desta análise estão apresentados na tabela 11.

Tabela 11 - Médias e erros-padrão dos resultados dos parâmetros de textura da carne reestruturada avaliada através de TPA

\begin{tabular}{|c|c|c|c|c|}
\hline Tratamentos & Dureza $(\mathrm{N})$ & $\begin{array}{l}\text { Elasticidade } \\
(\mathrm{cm})\end{array}$ & Coesividade $^{\star *}$ & $\begin{array}{l}\text { Mastigabilidade } \\
\text { (N.cm) }\end{array}$ \\
\hline 1_Controle & $\begin{array}{c}306,41^{\mathrm{a}} \pm \\
7,84\end{array}$ & $0,84^{b} \pm 0,01$ & $0,52^{a} \pm 0,01$ & $133,75^{\mathrm{a}} \pm 5,50$ \\
\hline 2_Canola & $\begin{array}{c}267,41^{b} \pm \\
7,84\end{array}$ & $0,84^{b} \pm 0,01$ & $0,46^{b} \pm 0,01$ & $104,75^{b} \pm 5,50$ \\
\hline 3_Antioxidante & $\begin{array}{c}312,29^{\mathrm{a}} \pm \\
7,84\end{array}$ & $0,82^{b} \pm 0,01$ & $0,46^{b} \pm 0,01$ & $120,65^{\mathrm{ab}} \pm 5,50$ \\
\hline 4_Canola_Antioxidante & $\begin{array}{c}257,10^{\mathrm{b}} \pm \\
7,84 \\
\end{array}$ & $0,88^{a} \pm 0,01$ & $0,49^{\mathrm{ab}} \pm 0,01$ & $112,36^{\mathrm{ab}} \pm 5,50$ \\
\hline
\end{tabular}

O tipo de tratamento apresentou efeito $(\mathrm{P}<0,05)$ nos parâmetros de dureza, elasticidade, coesividade e mastigabilidade.

Os tratamentos com adição de óleo de canola (tratamentos 2 e 4) apresentaram os menores valores de dureza $(267,41 \mathrm{~N}$ e $257,10 \mathrm{~N})(\mathrm{P}<0,05)$ e os tratamentos controle e com antioxidante apenas, os maiores valores $(306,41 \mathrm{~N} \mathrm{e}$ $312,29 \mathrm{~N})$. Álvarez et al. (2012) estudaram as propriedades texturais de salsichas de porco contendo óleos de canola e oliva, nozes e farelo de arroz e observaram que a dureza e a gomosidade foram maiores em salsichas feitas com toucinho em comparação com salsichas feitas com óleo de canola ou óleo de oliva e canola. Este aumento na consistência macia observada em salsichas contendo óleos vegetais também tem sido relatado por Özvural e Vural (2008), quando toucinho foi totalmente substituído por diferentes óleos e misturas de óleo durante a produção de salsichas. Hand et al. (1987) verificaram que salsichas com baixos teor de gordura foram mais duras, quando comparadas ao grupo controle. Similar redução da dureza e gomosidade também foi relatada em hamburgueres formulados com óleo de abacate, girassol e oliva em substituição a gordura, quando o toucinho foi reduzido para 50\% (RODRÍGUEZ-CARPENA; MORCUENDE; ESTÉVEZ, 2011). Contudo, Youssef e Barbut (2011) descobriram que a substituição da gordura da carne por óleo de canola ou pré-emulsionado de óleo de canola aumentou os valores de dureza, como resultado da criação de glóbulos de gordura muito 
menores nos tratamentos com óleo de canola, concluindo que a redução do teor de gordura diminuiu a dureza dos produtos cárneos, pois há maior teor de humidade nestes tratamentos e a água proporciona uma menor resistência à compressão. Lawrie (1998), sugere que a composição e as características de gordura influenciam as propriedades texturais de produtos cárneos.

Cestari (2007) encontrou valores de dureza em bifes reestruturados com salmoura em torno de $282,37 \mathrm{~N}$ a $333,72 \mathrm{~N}$, valores estes maiores em relação aos encontrados neste trabalho em reestruturados com óleo de canola, mostrando que o aumento na quantidade de óleo em bifes reestruturados reduz a dureza.

A elasticidade foi maior $(P<0,05)$ para a carne reestruturada com adição de óleo de canola mais antioxidante. A coesividade foi maior $(P<0,05)$ para 0 tratamento controle, mas não diferiu do tratamento com óleo de canola mais antioxidante.

Nielsen, Petersen e Moller (1995) relataram que a transglutaminase aumenta a força de ligação e coesividade entre os fragmentos de carne suína reestruturada, com valores de 0,41 para coesividade. Essas características influenciam a dureza e suculência da carne devido às interações entre sal e transglutaminase, e conseqüente aumento da umidade e CRA.

Em estudos realizados por Youssef e Barbut (2011) concluíram que a coesividade tende a diminuir conforme o conteúdo de gordura aumenta, a elasticidade tende a aumentar quando o nível de gordura aumenta e isto pode ser explicado pelo alto teor de gordura/óleo proporcionando mais elasticidade (isto é, a água não contribui para a elasticidade) e a mastigabilidade tende a mostrar a mesma tendência crescente quando a gordura da carne ou óleo de canola aumentam. Contudo neste estudo, a mastigabilidade foi menor $(P<0,05)$ para 0 tratamento com óleo de canola $(104,75 \mathrm{~N} . \mathrm{cm})$.

Cofrades et al. (2004) também observaram que quantidades crescentes de extratos de nozes reduz a força de cisalhamento e valores de alongamento, indicando a formação de estruturas de carne mais suaves e menos coesiva. Estes resultados texturais em amostras contendo nozes pode ser atribuído a possíveis interferências desses ingredientes durante o processo de gelificação das proteínas da carne, limitando a capacidade de ligação entre os componentes de emulsão da carne. Paulson e Tung (1989) sugeriram que a adição de proteínas não cárneas provavelmente atuam apenas como um diluente, diminuindo as interações da 
proteína da carne e gelificação, e resultando em textura mais suave do produto. De acordo com Jiménez-Colmenero et al. (2003), as proporções crescentes de gordura em amostras contendo nozes poderia ser responsável pela redução da coesão entre as peças de carne, contribuindo para a textura mais suave nessas amostras. Youssef e Barbut (2009) também descobriram que a dureza em carne cozidas mostrou valores mais elevados quando o nível de proteína foi aumentado de $10 \%$ a $15 \%$. Além disso, a adição de ingredientes também reduz a proporção de água disponível para formação de gel entre os pedaços de carne, que pode de novo limitar os processos de ligação (FAROUK; HALL; SWAN, 2000).

\subsubsection{DETERMINAÇÃO DA FORÇA DE CISALHAMENTO}

A textura da carne reestruturada também foi determinada utilizando-se da técnica denominada força de cisalhamento e os resultados estão apresentados na tabela 12.

Tabela 12 - Médias e erros-padrão dos resultados dos parâmetros de textura da carne reestruturada avaliada por meio da força de cisalhamento

\begin{tabular}{lc}
\hline \hline \multicolumn{1}{c}{ Tratamentos } & Força (N) \\
\hline \hline 1_Controle & $125,76^{\mathrm{a}} \pm 4,26$ \\
2_Canola & $96,10^{\mathrm{b}} \pm 4,26$ \\
3_Antioxidante & $123,64^{\mathrm{a}} \pm 4,26$ \\
4_Canola_Antixidante & $109,62^{\mathrm{ab}} \pm 4,26$ \\
\hline
\end{tabular}

${ }^{\mathrm{ab}}$ Médias na mesma coluna seguidas de letras iguais não diferem significativamente $(P>0,05)$.

O tipo de tratamento influenciou os valores de cisalhamento $(P<0,05)$, onde os bifes reestruturados com óleo de canola (tratamento 2 e 4) apresentaram menores valores de força $(96,10 \mathrm{~N}$ e $109,62 \mathrm{~N})$.

Cestari (2007) utilizou a mesma metodologia que faz uso da célula de corte para medição de força de cisalhamento em reestruturados bovinos e obteve valores de $107,65 \mathrm{~N}$ a $149,23 \mathrm{~N}$. Resultados semelhantes entre $105,49 \mathrm{~N}$ e $169,87 \mathrm{~N}$ também foram encontrados por Olivo (1999). 


\subsection{ANÁLISE SENSORIAL}

O perfil do consumidor foi distribuído da seguinte forma: $51,81 \%$ dos consumidores do sexo feminino e $48,19 \%$ do sexo masculino; $15,66 \%$ dos consumidores com idade até 20 anos, $75,90 \%$ com idade entre 21 - 40 anos e $8,44 \%$ com idade entre $41-60$ anos; $3,61 \%$ dos consumidores participantes não possuem escolaridade, $25,30 \%$ com ensino fundamental, $54,22 \%$ com ensino médio e 16,87\% com ensino superior; $100 \%$ dos consumidores gostam de carne bovina, onde $83,13 \%$ consomem carne bovina uma ou mais vezes por semana e 16,87\% consomem 2 ou 3 vezes ao mês.

É possível observar na figura 11 que $33,74 \%$ dos provadores pertenciam à classe $C, 55,42 \%$ à classe $B$ e $10,84 \%$ à classe $A$, que segundo a ANEP (2001) citado por Almeida (2010), a classe $B$ corresponde a $21 \%$ da população brasileira e possuem uma renda média familiar mensal entre $R \$ 1700,00$ a 2800,00 , a classe $A$ corresponde a $6 \%$ da população brasileira e possuem uma renda média familiar mensal entre $R \$ 4700,00$ a 7800,00 e a classe $C$ corresponde a $36 \%$ da população brasileira com uma renda familiar mensal de $\mathrm{R} \$ 927,00$. Desta forma, a grande maioria dos consumidores que participaram da análise sensorial $(89,16 \%)$ possuem de baixo a médio poder aquisitivo.

Figura 11 - Distribuição da classe econômica dos consumidores que realizaram a análise sensorial

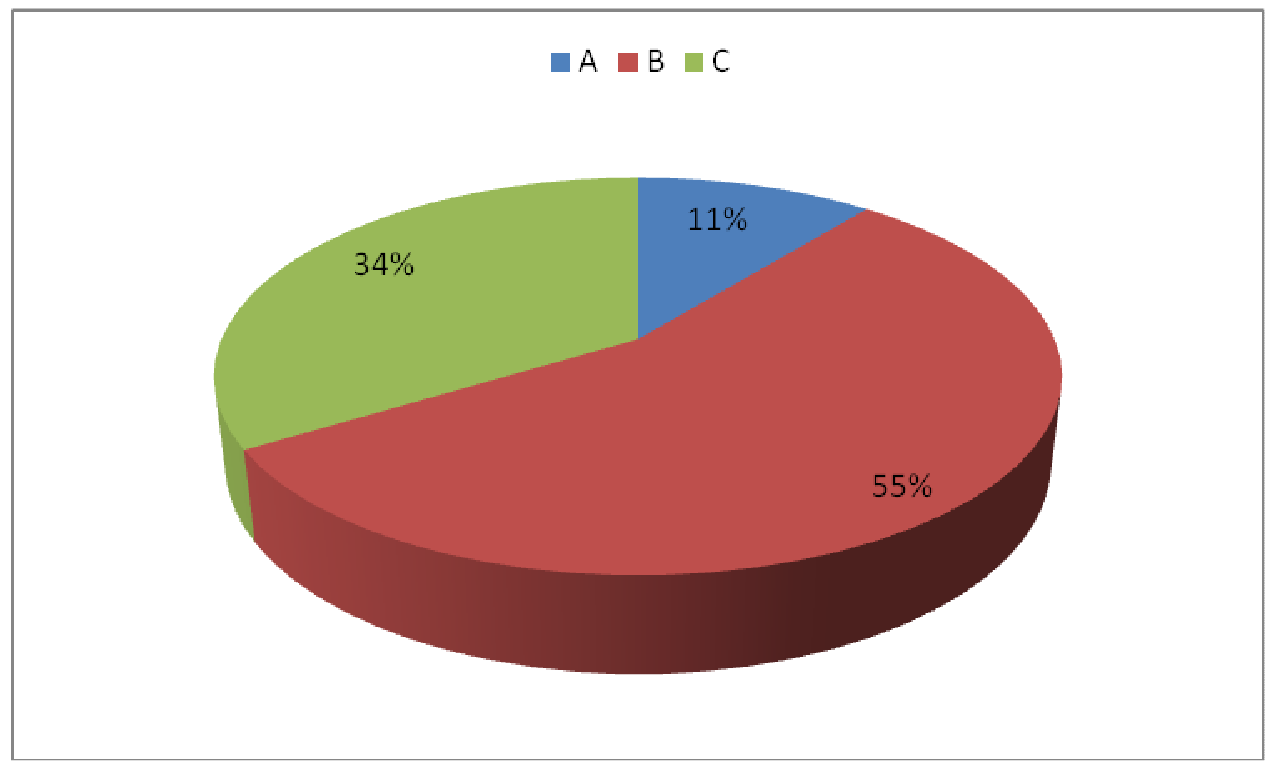


Em relação aos dados de aceitação dos quatro tratamentos de bifes reestruturados e em função dos três tempos de armazenamento do produto congelado não foram encontradas diferenças significativas $(P>0,05)$ nas médias de aceitação dos atributos de aroma, maciez e suculência (Tabela 13).

Tabela 13 - Médias e erros-padrão dos resultados da avaliação sensorial da carne reestruturada para os atributos aroma, maciez e suculência

\begin{tabular}{|c|c|c|c|}
\hline & Aroma & Maciez & Suculência \\
\hline "Tratamentos & & & \\
\hline 1 Controle & $7,65 \pm 0,11^{a}$ & $7,17 \pm 0,12^{a}$ & $7,24 \pm 0,13^{a}$ \\
\hline 2_Canola & $7,64 \pm 0,11^{a}$ & $7,35 \pm 0,12^{a}$ & $7,21 \pm 0,12^{a}$ \\
\hline 3_Antioxidante & $7,63 \pm 0,11^{a}$ & $7,23 \pm 0,12^{a}$ & $7,37 \pm 0,11^{a}$ \\
\hline $\begin{array}{c}\text { 4_Canola_Antioxidante } \\
\text { Tempo (dias) }\end{array}$ & $7,45 \pm 0,11^{a}$ & $7,20 \pm 0,12^{a}$ & $7,00 \pm 0,14^{a}$ \\
\hline 0 & $7,60 \pm 0,13^{a}$ & $7,42 \pm 0,15^{a}$ & $7,37 \pm 0,15^{a}$ \\
\hline 60 & $7,64 \pm 0,13^{a}$ & $7,19 \pm 0,16^{a}$ & $7,13 \pm 0,16^{a}$ \\
\hline 120 & $7,53 \pm 0,14^{a}$ & $7,11 \pm 0,17^{a}$ & $7,12 \pm 0,17^{a}$ \\
\hline Interações & Ns & Ns & Ns \\
\hline
\end{tabular}

No que diz respeito às médias dos valores de aceitação dos atributos avaliados, observou-se que para todos os atributos houve uma aceitação média, em torno de 7 (gostei moderadamente) a 8 (gostou muito) na escala hedônica. Portanto, os bifes reestruturados com adição de óleo de canola e eritorbato de sódio tiveram boa aceitação entre os consumidores que avaliaram os produtos, mesmo após 120 dias de armazenamento congelado. De acordo com as notas de aceitação, sugere-se que os bifes reestruturados podem ser mantidos em armazenamento congelado, sem quaisquer efeitos adversos sobre as principais características de qualidade.

Em relação aos resultados encontrados no presente estudo por meio das análises de força de cisalhamento e TPA observou-se que o óleo de canola melhorou a textura da carne reestruturada, porém esse efeito não foi percebido pelo grupo de consumidores que participaram da sensorial. Um dos motivos poderia ser o perfil dos consumidores, composto por grande número de pessoas de 
média e baixa renda, que constumam consumir carnes menos nobres, sendo assim menos exigentes quanto aos parâmetros avaliados.

Ao testar a adição de nozes em reestruturados, Serrano, Cofrades e Jiménez-Colmenero (2006), verificaram melhores resultados para a textura pelo painel sensorial, em relação ao controle. Resultados semelhantes foram relatados por Jiménez-Colmenero et al. (2003).

Segundo Stika et al. (2007), o antioxidante gaiato de propilo não influenciou a textura ou suculência de bifes reestruturados. Já, o tempo de armazenamento afetou os atributos sensoriais, em que observou-se que os escores de maciez e suculência diminuíram após 6 meses de congelamento dos produtos cárneos.

Posteriomente, Stika, Suman e Xiong (2008), concluíram que a inclusão de propil galato em reestruturados bovinos aumentou ligeiramente a suculência e aceitação global dos bifes em relação ao grupo controle. Porém, quando avaliadas as demais características sensoriais, os tratamentos foram similares, sugerindo que o antioxidante teve um benefício mínimo nas características sensoriais.

Segundo Robbins et al. (2002), bifes com injeção de cloreto de sódio/fosfato foram mais suculentos, quando comparados ao grupo controle, de acordo com uma equipe de provadores treinada, enquanto Robbins et al. (2003), aplicando os mesmo tratamentos do estudo anterior, verificaram que esses bifes foram mais macios e suculentos em relação ao tratamento controle, de acordo com a avaliação realizada por consumidores.

Houve interação $(\mathrm{P}<0,05)$ entre os tratamentos e 0 tempo de armazenamento congelado para os valores médios de aceitação do sabor sensorial (Tabela 14). 
Tabela 14. Médias e erros-padrão dos resultados da avaliação sensorial da carne reestruturada para o atributo de sabor

\begin{tabular}{|c|c|c|c|c|}
\hline \multirow{2}{*}{$\begin{array}{c}\text { Tempo } \\
\text { (dias) }\end{array}$} & \multicolumn{4}{|c|}{ Tratamentos } \\
\hline & 1_Controle & 2_Canola & 3_Antioxidante & 4_Canola_Antioxidante \\
\hline 0 & $7,72^{a f} \pm 0,21$ & $\begin{array}{c}7,33^{\text {af }} \pm \\
0,19\end{array}$ & $7,41^{\text {af }} \pm 0,20$ & $6,80^{\text {a g }} \pm 0,24$ \\
\hline 60 & $7,71^{\text {af }} \pm 0,22$ & $\underset{0,21}{7,43^{\text {af }} \pm}$ & $7,54^{a f} \pm 0,22$ & $7,30^{a f} \pm 0,25$ \\
\hline 120 & $7,06^{a f} \pm 0,24$ & $\begin{array}{c}7,65^{\mathrm{af}} \pm \\
0,22\end{array}$ & $7,04^{\mathrm{af}} \pm 0,23$ & $7,24^{a f} \pm 0,27$ \\
\hline
\end{tabular}

${ }^{\text {a-d Médias na mesma coluna seguidas de letras iguais não diferem }}$
significativamente $(P>0,05)$.

$\mathrm{f}$-h Médias na mesma linha seguidas de letras iguais não diferem significativamente $(P>0,05)$.

Ao analisar os resultados da tabela $14 \mathrm{em}$ linhas pode-se observar que apenas a carne reestruturada com adição de óleo de canola mais antioxidante ao dia zero de armazenamento apresentou média dos valores de aceitação menor $(P<0,05)$ para sabor, comparado aos demais grupos. No entanto, essa diferença no sabor não foi observada $(P>0,05)$ para os períodos 60 e 120 dias .

Observou-se também que não houve diferença $(P>0,05)$ no valor médio de aceitação do sabor, conforme progrediu o armazenamento dos produtos cárneos congelados, independente dos tratamentos testados $\mathrm{O}$ antioxidante eritorbato de sódio não influenciou o sabor dos bifes reestruturados, segundo os consumidores, ao longo do tempo. A falta de diferença na pontuação para o sabor ranço pelo consumidor é incompatível aos resultados encontrados neste estudo pela análise de TBARS, que indicam que houve um aumento $(P<0,05)$ na oxidação lipídica após os 60 dias de armazenamento. Sugere-se que, embora os valores de TBARS tenham sido diferentes ao longo do tempo de armazenamentos dos reestruturados, os consumidores não foram capazes de detectar esta diferença no painel sensorial, por meio da avaliação do sabor dos produtos.

De acordo com Stika et al. (2007), houve perdas de sabor e surgimento de "off flavor", se tornou mais intenso, à medida que bifes reestruturados foram congelados por 6 meses.

Por outro lado, Serrano, Cofrades e Jiménez-Colmenero (2006) observaram, por meio de teste sensorial com carne reestruturada, com adição de nozes, que 
não houve diferença para o sabor, não sendo detectado "off flavor" e que o congelamento $\left(-18^{\circ} \mathrm{C}\right)$ por até 92 dias não teve efeito sobre a qualidade sensorial dos bifes reestruturados. 


\section{CONCLUSÕES}

Os bifes reestruturados com adição de óleo de canola e eritorbato de sódio possuem propriedades físico-químicas e sensoriais aceitáveis, podendo ser comercializado como um produto de preparo rápido e possivelmente com maior valor agregado. Mais estudos precisam ser abordados no que respeita à utilização de óleo de canola em produtos cárneos.

\section{IMPLICAÇÕES}

A combinação do uso de cortes sem valor comercial, com a quantidade adequada de eritorbato de sódio, com o enriquecimento com óleo de canola e o armazenamento a $-18^{\circ} \mathrm{C}$ é de grande interesse para indústria, de modo a agregar valor e preservar as características qualitativas de produtos reestruturados de carne bovina.

Além dos métodos tradicionais, a indústria da carne disponibiliza um grande número de opções para modificar a composição qualitativa e quantitativa dos seus componentes para fins de saúde. O óleo de canola confere potenciais benefícios a saúde do coração. Ele pode ser mais prontamente ingerido se for incorporado em alimentos frequentemente consumidos de características adequadas, tais como produtos de carne reestruturada. A adição de óleo de canola alterou a composição dos bifes reestruturados, aumentou as perdas de cozimento, melhorou as características de textura, conferindo maior maciez, menor coesividade e menor mastigabilidade ao produto reestruturado. 


\section{REFERÊNCIAS}

ABNT. ASSOCIAÇÃO BRASILEIRA DE NORMAS TÉCNICAS. NBR 12806, Rio de Janeiro, 1993.

AKAMITTATH, J. G.; BREKKE, C. J.; SCHANUS, E. G. Lipid oxidation and color stability in restructured meat systems during frozen storage. Journal of Food Science, v.55, n.6, p.1513-1517, 1990.

ALLEN, C. D.; RUSSELL, S. M.; FLETCHER, D. L. The relationship of broiler breast meat color and $\mathrm{pH}$ to shelf-life and odor development. Poultry Science, v. 76, p.1042- 1046, 1997.

ALMEIDA, M. A. Transglutaminase e albumina de ovo em reestruturados cozidos congelados de frango. 2010, 92p. Dissertação (Mestrado) - Escola Superior de Agricultura "Luiz de Queiroz", Piracicaba, 2010.

ÁLVAREZ, D.; DELLES, R. M.; XIONG, Y. L.; CASTILLO, M.; PAYNE, F. A.; LAENCINA, J. Influence of canola-olive oils, rice bran and walnut on functionality and emulsion stability of frankfurters. LWT-Food Science and Technology, v. 44, p.1435-1442, 2011.

ÁLVAREZ, D.; XIONG, Y. L.; CASTILLO, M.; PAYNE, F. A.; GARRIDO, M. D. Textural and viscoelastic properties of pork frankfurters containing canola-olive oils, rice bran, and walnut. Meat Science, V.92, p.8-15, 2012.

AMSA. AMERICAN MEAT SCIENCE ASSOCIATION Research Guidelines for Cookery, Sensory Evaluation and Instrumental Tenderness Measurements of Fresh Meat. National Livestock and Meat Board, Chicago, IL, 1995, 48p.

ANJANEYULU, A. S. R., SHAMA, N. AND KONDAIAH, N. Evaluation of salt, polyphosphates and their blends at different levels on physicochemical properties of buffalo meat and patties. Meat Science, v.25, p. 293-306, 1989.

AOAC. ASSOCIATION OF OFICIAL ANALYTICAL CHEMISTS. Official methods of analysis. 16ed. Gaithersburg, 1998.

APPLE, J. K.; RAKES, L. K.; WATSON, H. B. Cooking and shearing methodology effects on Warner-Bratzler shear force values of pork. Journal of Muscles Foods, v. 10, p. 269-277, 1999.

ARGANOSA, G. C.; GODBER, J. S.; TANCHOTIKUL, U.; MCMILLIN, K. W.; SHAO, K.P. Processing ingredients affecting oxidative and textural stability of restructured beef roasts. Journal of Food Science, v.56, p.1480-1483, 1991. 
ASHRAF, M.; McNEILLY, T. Salinity tolerance in some Brassica oilseed. Critical Reviews in Plant Sciences, v. 23, n. 2, p. 157-174, 2004.

ATOUI, A. K.; MANSOURI, A.; BOSKOU, G.; KEFALAS, P. Food Chemistry, v. 89, p. 27-36, 2005.

AWAD, A.; POWRIE, W. D.; FENNEMA, O. Chemical deterioration of frozen bovine muscle at_4_C. Journal of Food Science, v.33, p. 227-235, 1968.

AWAD, A. B.; FINK, C. S. Phytosterols as anticancer dietary components: evidence and mechanism of action. Journal of Nutrition, v.130, p.2127-2130, 2000.

BAILEY, A. J. The basis of meat texture. Journal of the Science of Food and Agriculture, Chichester, v. 23, p. 995-1107, 1972.

BARBUT, S. Poultry products-formulations and gelation. Poultry products processing: an industry guide. Boca Raton: CRC Press, 2002. chap. 9, p.249287.

BARREIROS, A. L. B. S.; DAVID, J. M.; DAVID, J. P. Oxidative stress: relations between the formation of reactive species and the organism's defense. Química Nova, v.29, p. 113-123, 2006.

BAUBLITS, R. T.; POHLMAN, F. W.; BROWN, A. H.; JOHNSON, Z. B. Effects of sodium chloride, phosphate type and concentration, and pump rate on beef biceps femoris quality and sensory characteristics. Meat Science, v. 70, p. 205-214, 2005.

BAUBLITS, R. T.; POHLMAN, F. W.; BROWN JR, A. H.; YANCEY, E. J.; JOHNSON, Z. B. Impact of muscle type and sodium chloride concentration on the quality, sensory, and instrumental color characteristics of solution enhanced wholemuscle beef. Meat Science, v. 72, p.704-712, 2006.

BELL, J. M. Factors affecting the nutritional value of canola meal: a review.

Canadian Journal of Animal Science, v. 73, n. 4, p. 679-697, 1993.

BENDALL, J. The swelling effect of polyphosphates on lean meat. Journal of Science Food Agriculture, v.5, p.468, 1972.

BERNAL, W. V. W.; BERNAL, V. M.; GULLETT, E. A.; STANLEY, D. W. Sensory and objective evaluation of a restructured beef products. Journal of Texture Studies, v. 19, p. 231-248, 1988.

BERNTHAL, P. H.; BOOREN, A. M.; GRAY, J. I. Effect of reduced sodium chloride concentration and tetrasodium pyrophosphate on $\mathrm{pH}$, water-holding capacity and extractable protein of prerigor and postrigor ground beef. Meat Science, v. 29, p. 69-82, 1991. 
BHATTACHARYA, M.; HANNA, M. A.; MANDIGO, R. W. Effect of frozen storage conditions on yields, shear strength and color of ground beef patties. Journal of Food Science, v. 53, n. 3, p. 696-700, 1988a.

BHATTACHARYA, M.; HANNA, M. A.; MANDIGO, R. W. Lipid oxidation in ground beef patties as affected by time-temperature and product packaging parameters. Journal of Food Science, v. 53, n. 3, p. 714-717, 1988b.

BOURNE, M. C. Texture profile analysis. Food Technology, Chicago, v.32, $\mathrm{n}^{\circ} 2$, p.62-66, 1978.

BOURNE, M. C. Food texture and viscosity: concept and measurement. New York: Academic Press, 1982. 325p.

BRAGAGNOLO, N; RODRIGUEZ-AMAYA, D.B. Teores de colesterol em carne suína e bovina e efeito do cozimento. Ciência Tecnologia de Alimentos, v.15, p.11, 1995.

BRASIL. Agência Nacional da Vigilância Sanitária. Instrução Resolução RDC n¹2 de 02 de janeiro de 2001. Aprova o regulamento técnico sobre padrões microbiológicos para alimentos. Disponível em: $<$ http://eegis.

bvs.br/leisref/public/showAct.php?id=144\&word=produtos\%20c\%c3\%a1rneos.> Acesso em 15/05/2010.

BRASIL. Ministério da Agricultura e do Abastecimento. Instrução Normativa n.20 de 21 de julho de 1999. Oficializa os métodos analíticos físico-químicos, para controle de produtos cárneos e seus ingredientes - sal e salmoura. Disponível em: Disponível em:

<http://oc4j.agricultura.gov.br/agrolegis/do/consultaLei?op=viewTextual\&codigo=28 55.> Acesso em 15/01/2012.

BREWER, M. S.; HARBERS, C. A. Z. Effect of packaging on physical and sensory characteristics of ground pork in long-term frozen storage. Journal of Food Science, v. 56, n. 3, p. 627-631, 1991.

CAMARGO, P. J. C. C. Influência da transglutaminase (activa $\left.{ }^{\circledR} \operatorname{tg}-b\right)$ e de parâmetros de processo na textura de um reestruturado empanado de carne de peru. 1999. 100f. Tese (Mestrado em Tecnologia de Alimentos). Faculdade de Engenharia de Alimentos, Universidade Estadual de Campinas. Campinas, 1999.

CARMACK, C. F.; KASTNER, C. L.; DIKEMAN, M. E.; SCHWENKE, J. R.; ZEPEDA, C. M. G. Sensory evaluation of beef-flavor-intensity, tenderness, and juiciness among major muscles. Meat Science, v. 39, p. 143-147, 1995.

CESTARI, L. A. Carne bovina reestruturada com transglutaminase: desenvolvimento e determinações de cor e textura. 2007. 88f. (Dissertação de Mestrado). Universidade Estadual de Campinas, Campinas, 2007. 
CHASTAIN, M. F.; HUFFMAN, D. L.; HSIEH, W. H.; CORDRAY, J. C.Antioxidants in restructured beef/pork steaks. Journal of Food Science, v. 47, p. 1779-1782, 1982.

CHEFTEL, J.C.; CUQ, J.-L.; LORIENT, D. Proteinas alimentarias. Zaragoza: Acribia, 1989. p. 179-220; 291-335.

CHEN, C. M.; TROUT, G. R. Sensory, instrumental texture profile and cooking properties of restructured beef steaks made with various binders. Journal of Food Science, v. 56, n. 6, p. 1457-1460, 1991.

CHRISTIE, W. W. A simple procedure for rapid transmethylation of glicerolipids and cholesterol esters. Journal of Lipid Research, v. 23, p. 1072, 1983.

CIPOLLI, K. M. V. A. B. Efeito da marinação da estimulação elétrica e da desossa a quente sobre propriedades físicas, químicas, tecnológicas e sensoriais em M. Triceps brachii (coração da paleta) da raça Nelore. 2004. 152f. Dissertação (Mestrado em Tecnologia de Alimentos) - Faculdade de Engenharia de Alimentos. Universidade Estadual de Campinas. Campinas, 2004.

COFRADES, S.; SERRANO, A.; AYO, J.; SOLAS, M. T.; CARBALLO, J.; JIMÉNEZ COLMENERO, F. Restructured beef with different proportions of walnut as affected by meat particle size. European Food Resesearch and Technology, v. 218, p. 230-236, 2004.

COLMENERO, F. J.; SERRANO, A.; AYO, J.; SOLAS, M. T.; COFRADES, S.; CARBALLO, J. Physicochemical and sensory characteristics of restructured beef steak with added walnuts. Meat Science, v. 65, p. 1391-1397, 2003.

COMBS, G.F. The Vitamins: fundamental aspects in nutrition and health. San Diego, Califórnia, 1992, p.179-201.

CORNER, E.J.; BRUCE, V.M.; McDONALD, B.E. Accumulation of eicosapentaenoic acid in plasma phospholipids of subjects fed canola oil. Lipids., v.25,p.598-601, 1990.

COSTA, E. C.; RESTLE, J.; BRONDANI, I. L.; PEROTTONI, J.; FATURI, C.; MENEZES, L. F. G. Composição física da carcaça, qualidade da carne e conteúdo de colesterol no músculo longissimus dorsi de novilhos red angus superprecoces, terminados em confinamento e abatidos com diferentes pesos. Revista Brasileira de Zootecnia, v.31, n.1, p.417-428, 2002.

COULATE, T.P. Alimentos: Química de sus componentes. Editorial Acribia, Zagaroza - España; 1984.

COUNSELL, J. N.; HORNIG, D. H. Vitamin C (ascorbic acid). England: Applied Science, 1981. cap. 7 . 
CULLER, R. D.; PARRISH JUNIOR, F. C.; SMITH, G. C.; CROSS, H. R. Relationship of myofibril fragmentation index to certain chemical, physical and sensory characteristics of bovine longissimus muscle. Journal of Food Science, v. 43, p. 1177-1180, 1978.

D'OLIVEIRA, P. S; PRADO, I. N.; SANTOS, G. T. Efeito da Substituição do farelo de soja pelo farelo de canola sobre o desempenho de novilhas Nelore confinadas. Revista Brasileira de Zootecnia, v. 26, n. 3, p. 568-574, 1997.

DIMITRAKOPOULOU, M. A.; AMBROSIADIS, J. A.; ZETOU, F. K.; BLOUKAS, J. G. Effect of salt and transglutaminase (TG) level and processing conditions on quality characteristics of phosphate-free, cooked, restructured pork shoulder. Meat

Science, v. 70, p. 743-749, 2005.

DOBSON, B. N., MOISEEV, I. V., CORNFORTH, D. P., SAVELLO, P., WOOD, R. J. AND ANDERSON, R. Instrument for measuring bind strength of restructured and emulsion-type meat products. Journal of Texture Studies, v. 24, p. 303-3 10, 1993.

DRANSFIELD, E. Optimization of tenderization, ageing and tenderness. Meat Science, Barking, v. 36, p. 105- 121, 1994.

ECHARTE, M.; ANSORENA, D.; ASTIASARÁN, I. Consequences of microwave heating and frying on the lipid fraction of chicken and beef patties. Journal of Agriculture Food Chemistry, v. 51, n. 20, p. 5941-5, 2003.

ESGUERRA, C. M. Quality of cold-set restructured beef steak: effects of various binders, marination and frozen storage. Meat Industry Research Institute of New Zealand. Publication MIRINZ 945, 1994.

FAROUK, M. M.; HALL, W. K.;SWAN, J. E. Attributes of beef sausages, batters, patties and restructured roasts from two boning systems. Journal of Muscle Foods, v.11, p.197-212, 2000.

FELÍCIO, P. E. Qualidade da carne Nelore e o mercado mundial. 2000. Disponível em: <http:/www.fea.unicamp.br/lab/carnes/textos.htm> Acesso em: Janeiro de 2012.

FENNEMA, O.R.Química de los alimentos. Segunda edição, Editorial Acribia, Zagaroza - España, 2000.

FERNÁNDEZ-GINÉS, J.M.; FERNÁNDEZ-LÓPEZ, J.; SAYAS-BARBERÁ, E.; PÉREZ-ÁLVAREZ, J. A. Meat products as functional foods: A review. Journal of Food Science, v. 70, p. 37-43, 2005.

FERREIRA, V. L. P. Análise sensorial: testes discriminativos e afetivos. Campinas, SP.: SBCTA, 2000, 127p. 
FLORES, N. C.; BOYLE, E. A. E.; KASTNER, C. L. Instrumental and consumer evaluation of pork restructured with Activa TM or with Fibrimex TM formulated with and without phosphate. Food Science and Technology/LWT, v. 40, p. 179-185, 2007.

FORREST, J. C.; ABERLE, E. D.; HEDRICK, H. B; JUDG, M. D.; MERKEL, R. A. Fundamentos de ciência de la carne. Editorial Acribia, Zagaroza. España, 1979.

FRANCO, B. D. G. M.; LANGDRAF, M. Microbiologia dos alimentos. Editora Atenel, São Paulo: 2003.

FURUYA, V. R. B.; HAIASHI, C.; FURUYA, W. M. Farelo de canola na alimentação de Tilápia do Nilo (Oreochromis nilóticos L.) durante o período de reversão do sexo. Revista Brasileira de Zootecnia, v. 26, n. 6, p. 1067-1073, 1997.

GALDIOLI, E. M.; HAYASHI, C.; SOARES, C. M.; FURUYA, V. R. B.; FARIA, A. C. E. Substituição da proteína do farelo de soja pela proteína do farelo de canola em rações para alevinos de Curimbatá. Revista Brasileira de Zootecnia, v. 31, n. 2, p. 552-559, 2002.

GALVIN, K.; MORRISEY, P. A.; BUCKLEY, D. J. Cholesterol oxides in processed chicken muscle as influenced by dietary a-tocopherol supplementation. Meat Science, v.48, n. 1/2, p.1-9, 1998.

GERRARD, J. A. Protein-protein crosslinking in food: methods, consequences, applications. Trends in Food Science and Technology, v. 13, p. 391-399, 2002.

GHAVIMI, B.; ALTHEN, T. G.; ROGERS, R. W. Effects of tumbling at various speeds on some characteristics of restructured cured beef. Journal of Food Science, v. 52, n. 3, p. 543-544, 553, 1987.

GIESE, J. Developing low-fat meat products. Food Technology, v. 46, p. 100-108, 1992.

GIESE, J. Fats, oils, and fat replacers. Food Technology, v. 50, p. 78-83, 1996.

GRAY, J. I.; GOMAA, E. A.; BUCKLEY, D. J. Oxidative quality and shelf-life of meats. Meat Science, v.43, p. 111-113, 1996.

GRAY, J. I.; PEARSON, A. M. Rancidity and warmed over flavor. In: Advances in Meat Reseach, v. 3, New York, AVI Book, 1987.

GROMBACHER, A.; NELSON, L. Canola production. Lincoln: University of Nebraska, 1992. 
GRUNERT, K. G. What's in a steak? A cross-cultural study on the quality perception of beef. Food Quality and Preference, v.8, n.3, p.157-174, 1997.

GUSTAFSSON, I. B.; VESSBY, B.; OHRVALL, M.; NYDAHL, M. A diet rich in monounsaturated rapeseed oil reduces the lipoprotein cholesterol concentration and increases the relative content of $n-3$ fatty acids in serum in hyperlipidemic subjects. American Journal of Clinical Nutrition, v. 59, p. 667-674, 1994.

HAGERMAN, A.E., RIEDL, K.M., JONES, A., SOVIK, K.N., RITCHARD, N.T., HARTZFELD, P.W. and RIECHEL, T.L. High molecular weight plant polyphenolics (tannins) as antioxidants. Journal.of Agriculture.of Food Chemistry, v. 46, p. 1887- 1892, 1998.

HALLIWELL, B.; CHIRICO, S. Lipid peroxidation: its mechanism, measurement and significance. American Journal of Clinical Nutrition, v. 57, p. 715-725, 1993.

HAMMER, G. F. Processing vegetable oils into frankfurter-type sausages.

Fleischwirtschaft, v. 72, p. 1258-1265, 1992.

HAND, L. W.; HOLLINGSWORTH, C. A.; CALKINS, C. R.; MANDIGO, R. W. Effects of preblending, reduced fat and salt levels on frankfurter characteristics. Journal of Food Science, v. 52, p.1149-1151, 1987.

HARA, A.; RADIN, N. S. Lipid extration of tissues of low-toxicity solvent. Analytical Biochemistry, v. 90, p. 420-426, 1978.

HSU, S. Y.; YU, S. H. Comparisons on 11 plant oil fat substitutes for low-fat Kungwans. Journal of Food Engineering, v. 51, p.215-220, 2002.

HUIDOBRO, F. R.; MIGUEL, E.; BLÁZQUEZ, E. A comparison between two methods (Warner-Bratzler and texture profile analysis) for testing either raw meat or cooked meat. Meat Science, n.69, p.527-536, 2005.

HUFFMAN, D. L.; CORDRAY, J. C. Processing systems - particle reduction systems (grinding, flaking, chunking, slicing). In: International Symposium of Meat Science and Technology, Nebraska, p.229-233, 1982.

HUFFMAN, K. L.; MILLER, M. F.; HOOVER, S. C.; WU, C. K.; BRITTIN, H.C.; RAMSEY, C. B. Effect of beef tenderness on consumer satisfaction with steaks consumed in the home and restaurant. Journal of Animal Science, v. 74, p. 91-97, 1996.

HUFFMAN, D. L.; MCCAFFERTY, D. M.; CORDRAY, J. C.; STANLEY, M. H. Restructured beef steaks from hot-boned and cold-boned carcasses. Journal of Food Science, v. 49, p. 164-167, 1984.

IMMONEN, K.; RUUSUNEN, M.; HISSA, K.; PUOLANNE, E. Bovine muscle 
glycogen concentration in relation to finish diet, slaughter and ultimate $\mathrm{pH}$. Meat Science, v. 55, n. 1, p. 25-31, 2000.

JACOBS, D. J.; SEBRANEK, J. G. Use the prerigor beef for frozen ground beef patties. Journal of Food Science, v. 45, p. 648, 1980.

JANERO, D. R. Malondialdehyde and thiobarbituric acid-reactivity as diagnostic indices of lipid peroxidation and peroxidative injury. Free Radicals in Biology and Medicine, v. 9, p.515-540, 1990.

JIMÉNEZ COLMENERO, F.; SERRANO, A.; AYO, J.; SOLAS, M. T.; COFRADES, S.; CARBALLO, J. Physicochemical and sensory characteristics of restructured beef steak with added walnuts. Meat Science, v. 65, n. 4, p. 1391-1397, 2003.

JO, C.; AHN, D. U. Fluorometric analysis of 2-thiobarbituric acid reactive substances in turkey. Poultry Science, Savoy, v. 77, p. 475-480, 1998.

JUDGE, M.; ABERLE E. D.; FORREST, J. C.; HEDRICK, H. B.; MERKEL, R. A. Principles of meat science. Dubuque: Kendall/Hunt, p. 351, 1989.

KANG, I.J. et al. Gelation and properties of soybean glycinin in a transglutaminasecatalyzed system. Journal of Agriculture of Food Chemistry, v. 42, p.159-165, 1994.

KEETON, J. T. Formed and emulsion products. In; SAMS, A. R. (Ed.). Poultry meat processing. Boca Raton: Lewis Publishers, 2001, cap. 12, p.195-226.

KEETON, J. T. Low-fat meat products - Technological problems with processing. Meat Science, v. 36, p. 241-276, 1994.

KELLER, J. D.; KINSELLA, J. E. Phospholipid changes and lipid oxidation during cooking and frozen storage of raw ground Beef. Journal of Food Science, v. 38, p.1200-1204, 1973.

KIM, J. S.; GODBER, J. S.; PRINAYWIWATKUL, W. Restructured beef roasts containing rice bran oil and fiber influences cholesterol oxidation and nutritional profile. Journal of Muscle Foods, v. 11, p. 111-127, 2000.

KNIPE, C. L.; OLSON, D. G; RUST, R. E. Effects of selected inorganic phosphates, phosphate levels and reduced sodium chloride levels on protein solubility, stability and $\mathrm{pH}$ of meat emulsions. Journal of Food Science, v. 50, p. 1010-1013, 1985.

KOOHMARAIE. M. Postmortem proteolysis in Longissimus muscle from beef, lamb and pork carcasses. Journal Animal Science, v. 69, p. 617-624, 1991. 
KOOHMARAIE, M. Muscle proteinases and meat aging. Meat Science, Barking, v. 36, p. 93-104, 1994.

KRIS-ETHERTON, P. M. AHA science advisory. Monounsaturated fatty acids and risk of cardiovascular disease. American Heart Association. Nutrition

Committee. Circulation, v. 100, n. 11, p.1253-1258, 1999.

KRYGIER, K.; SOSULSKI, F.; HOGGE, L. Free, esterified and insoluble phenolic acids. 2. Composition of phenolic acids in rapeseed flour and hulls, Journal of Agriculture Food Chemistry,. v. 30, p. 334-336, 1982.

KUBOW, S. Lipid oxidation products in food and atherogenesis. Nutrition Reviews Journal, Hoboken, v. 51, n. 2, p. 33-40, 1993.

KURAISHI, C.; YAMAZAKI, K.; SUSA, Y. Transglutaminase: Its utilization in the food industry. Food Reviews International, v. 17, n. 2, p. 221-246, 2001.

KUTEMEYER, C.; FROECK, M.; WERLEIN, H. D.; WATKINSON, B. M. The influence of salts and temperature on enzymatic activity of microbial transglutaminase. Food Control, v. 16, p. 735-737, 2005.

KWON, J. S.; SNOOK, J. T.; WARDLAW, G. M.; HWANG, D. H. Effects of diets high in saturated fatty acids, canola oil, or safflower oil on platelet function, thromboxane B2 formation, and fatty acid composition of platelet phospholipids. The American Journal of Clinical Nutrition, v. 54, p. 351-358, 1991.

LAMKEY, J. W.; MANDIGO, R. W.; CALKINS, C. R. Effect of salt and phosphate on the texture and color stability of restructured beef steaks. Journal of Food Science, v. 51, p. $873-875,911,1986$.

LAWRIE, R. A. The eating quality of meat. IN R. A. LAWRIE (ED.), Meat Science, 6TH ED. CAMBRIDGE: WOODHEAD PUBLISHING, 1998.

LEE, B. J.; HENDRICKS, D. G.; CORNFORTH, D. P. Effect of Sodium Phytate, Sodium Pyrophosphate and Sodium Tripolyphosphate on Physico-chemical Characteristics of Restructured Beef. Meat Science, v. 50, n. 3, p. 273-283, 1998.

LEE, S.K.; MEI, L.; DECKER, E.A. Lipid oxidation in cooked turkey as affected by added antioxidant enzymes. Journal of Food Science, Chicago, v. 61, n. 4, p. 726728, July/Aug. 1996.

LEE, C. M.; CARROLL, R. J.; ARDOLLAHI, A. A microscopical study of structure of meat emulsions and its relationship to thermal stability. Journal of Food Science, v. 46, p. $1789-1796,1981$. 
LEHNINGER, A. L.; NELSON, D. L.; COX, M. M. The biosyntesis of lipids. In: LEHNINGER, A.L. (Ed.) Principles of biochemistry. 3.ed. New York: Worth Publishers, 2000, p. 770-817.

LEMOS, A. L. S. C. Ingredientes e aditivos no processamento de embutidos. In: Princípios do processamento de embutidos cárneos, ISBN 85-7029-056-X, p.11-27, 2002.

LENNON, A. M.; MOON, S. S.; WARD, P.; NEILL, E. E. O.; KENNY, T. Effects of enhancement procedures on whole and re-formed beef forequarter muscles. Meat Science, v. 72, p. 513-517, 2006.

LI, R.; CARPENTER, J. A.; CHENEY, R. Sensory and instrumental properties of smoked sausage made with Mechanically Separated Poultry (MSP) meat and wheat protein. Journal of Food Science, v. 63, n. 5, 1998.

LIVINGSTON, M.; BREWER, M. S.; KILLIFER, J.; BIDNER, B.; MCKEITH, F. Shelf life characteristics of enhanced modified atmosphere packaged pork. Meat

Science, 68, 115-122, 2004.

LUCHIARI FILHO, A. Pecuária da carne bovina. 1.ed. São Paulo: Luchiari Filho, 134p., 2000.

MADRUGA, M. S.; FIGUEIREDO, M. J.; NUNES, M. L.; LIMA, F. M. S. Teores de colesterol de lingüiças de frango light e tradicionais. Ciência e Tecnologia de Alimentos, Campinas, v. 24, p. 527-531, 2004.

MANCINI, R. A.; HUNT, M.C. Current research in meat color - Review. Meat Science, v. 71, p. 100-121, 2005.

MANDIGO, R. W. Processing Systems - Mixing, Temperature Control and Raw Materials. In: International symposium of meat science and technology, Nebraska, p.235-243, 1982.

MARASCHIELLO, C.; ESTEVE, E.; GARCÍA-REGUEIRO, J. A. Cholesterol oxidation in meat from chickens fed a-tocopherol and B-carotene-supplemented diets with different unsaturation grades. Lipids v. 33, n. 7, p. 705-13, 1998.

MARQUEZ, E. J.; AHMED, E. M.; WEST, R. L.; JOHNSON, D. D. Emulsion stability and sensory quality of beef frankfurters produced at different fat or peanut oil levels. Journal of Food Science, v. 54, p. 867-870, 1989.

MARSH, B. B. The basis of quality in muscle foods: symposium the basis of tenderness in muscle foods. Journal of Food Science, v. 42, n. 2, p. 295- 297, 1977. 
MATTSON, F. H.; GRUNDY, S. M. Comparison of effects of dietary saturated, monounsaturated, and polyunsaturated fatty acids on plasma lipids and lipoproteins in man. Journal of Lipid Research, v. 26, p. 194-202, 1985.

McCARTHY, T. L.; KERRY, J. P.; KERRY, J. F.; LYNCH, P. B.; BUCKLEY, D. J. Evaluation of the antioxidant potential of natural food/plant extracts as compared with synthetic antioxidants and vitamin E in raw and cooked pork patties. Meat Science, v.57, p.45-52, 2001.

MCMILLIN, K. W.; BIDNER, T. D.; FELCHLE, S. E.; DUGAS, S. M.; KOH, K. C. Flavor and oxidative stability of ground beef patties as affected by source and storage. Journal of Food Science, v. 56, n. 4, p. 899-902, 1991.

MEILGAARD, M.; CIVILLE, G.V.; CARR, B.T. Sensory evaluation techniques, Boca Raton, CRC Press 1999. 281p.

MILLER, A. J.; ACKERMAN, S. A.; PALUMBO, S. A. Effects of frozen storage on functionality of for processing. Journal of Food Science, v. 45, p. 1466-1471, 1980.

MOLINS, R. A. Phosphates in food, Inc. Boca Raton, . CRC Press, 1991, 261p.

MOISEEV, I. V.; COMFORTH, D. P. Sodium hydroxide and sodium tripolyphosphate effects on bind strength and sensory characteristics of restructured beef rolls. Meat Science, v. 45, p. 53-60, 1997.

MOTOKI, M.; KUMAZAWA, Y. Recent research trends in transglutaminase technology for food processing. Food Science and Technology Research, v. 6, n. 3, p. 151-160, 2000.

MOTOKI. M.; SEGURO, K. Transglutaminase and its use for food processing Review. Trends in Food Science and Technology, v. 9, p. 204-201, 1998.

MOZAFFARIAN, D.; ASCHERIO, A.; HU, F. B.; STAMPFER, M. J.; WILLETT, W. C.; SISCOVICK, D. S. Interplay between different polyunsaturated fatty acids and risk of coronary heart disease in men. Circulation, v. 111, p. 157-164, 2005.

MUHAMMAD, S.; KHALIL, I. A.; KHAN, S. Fatty acid composition of rape and mustard oilseed cultivars. Khyber Science Journal, v. 4, n. 1, p. 29-36, 1991.

NACZK, M.; AMAROWICZ, R.; PINK, D.; SHAHIDI, F. Insoluble condensed tannins of canola and rapeseed hulls. J. Agric. Food Chemistry, v. 48, p. 1758-1762, 2000.

NACZK, M.; NICHOLS, T.; PINK, D.; SOSULSKI, F. Condensed tannins in canola hulls. J. Agric. Food Chemistry, v. 42, p. 2196-2200, 1994. 
NARDIN, T. R. F.; GRANER, M.; VERRUMA-BERNARDI, M. R. Produtos de emulsão (fiambres) elaborados com carne de poedeiras leves (leghorn) de descarte e óleos vegetais. Science Agriculture. v. 56, n.2, p 210-252, 1999.

NIELSEN, G. S.; PETERSEN, B. R.; MØLLER, A. J. Impact of Salt, Phosphate, and temperature on the Effect of Tansglutaminase (F XIIla) on the Texture of Restructured Meat. Meat Science, v. 41, n. 3, p. 293-299, 1995.

NONAKA, M. Improvement of the pH-solubility profile of sodium caseinate by using $\mathrm{Ca} 2+-$ independent microbial transglutaminase with gelatin. Food Hydrocolloids, v. 11, p. 347-349, 1997.

NONAKA, M. Sodium caseinate and skim milk gels formed by incubation with microbial transglutaminase. Journal Food Science, v. 57, p. 1214-1218, 1992.

NUS, M.; RUPERTO, M.; SÁNCHEZ-MUNIZ, F. J. Nuts, cardio and cerebrovascular risks. A Spanish perspective. Archivos Latinoamericanos de Nutricion, v.54, n. 2, p.137-148, 2004.

NYDAHL, M.; GUSTAFSSON, I. B.; OHRVALL, M.; VESSBY, B. Similar effects of rapeseed oil (canola oil) and olive oil in a lipid-lowering diet for patients with hyperlipoproteinemia. Journal of American College of Nutrition, v. 14, p. 643$651,1995$.

OHTSUKA, T.; UMEZAWA, Y.; NHIO, N.; KUBOTA, K. Comparison of deamidation activity of transglutaminases. Journal of Food Science, v. 66, p. 25-29, 2001.

OLIVO, R. O mundo do frango. Criciúma, Ed. autor, 2006, 680 p.

OLIVO, R. Carne PSE em frangos.1999. 88f. Tese (Doutorado). Faculdade de Ciências Farmacêutica - Universidade de São Paulo, São Paulo, 1999.

OMONI, A. O.; ALUKO, R. E. Trends in Food Science and Technology, v.16, p.344-347, 2005.

OSAWA, C. C.; FELÍCIO, P. E.; GONÇALVES, L. A. G. Teste de TBA aplicado a carnes e derivados: métodos tradicionais, modificados e alternativos. Química Nova, v XY, p.1-9, 2005.

ÖZVURAL, E. B.; VURAL, H.. Utilization of interesterified oil blends in the production of frankfurters. Meat Science, v. 78, p. 211-216, 2008.

OWENS, C. M. Coated poultry products. In: SAMS, A. R. Poultry meat processing. Boca Raton: Lewis Publishers, 2001, p. 227-242, cap. 14. 
PANERAS, E. D.; BLOUKAS, J. G. Vegetable oils replace pork backfat for low-fat frankfurter. Journal of Food Science, v. 59, p. 725-728, 733, 1994.

PAULSON, A. T.;TUNG, M. A. Microstructure and texture of meat emulsions supplemented with plant proteins. Food Microstructure, v.8, p.41-51, 1989.

PENFIELD, M. P.; SWANSON, R. B.; MITCHELL, D. S.; REIMANN, M. J.; DORKO, C. L. Restructured reindeer steaks: effect of flake size, phosphate, and salt on sensory properties. Journal of Food Science, v. 57, n. 1, p. 252-253, 255, 1992.

PEARSON, A. M.; GILLETT, T. A. Processed meats. 3.ed. New York: Chapman \& Hall, 1996, 448p.

PEARSON, A. M.; DUTSON, T. R. Restructured Meat and Poultry Products. Advances in Meat Research Westport, Connecticut: AVI Publishing Co., 1987, 519p.

PEARSON, A. M.; GRAY, I. J.; WOLZAK, A. M.; HORENSTEIN, N. A. Safety implications of oxidized lipids in muscle foods. Food Technology, v. 37, n. 7, p. 121-130, 1983.

PELLEGRINI, L. G.; PELLEGRINI, L. F. V.; PELEGRIN, A. C. R. S.; PIRES, C. C. Efeito do tempo de armazenamento sob as características físicoquímicas da carne ovina. Synergismus Scyentifica UTFPR, v. 7, n. 1, 2012.

RASHCHI, F.; FINCH, J. A. Polyphosphate: a review. Their chemistry and application with particular reference to mineral processing. Minerals Engineering, v. 13, n. 10-11, p. 1019-1035, 2000.

PEREIRA, N. R.; TARLEY, C. R. T.; MATSUSHITA, M.; SOUZA, N. E. Proximate composition and fatty acid profile in Brazilian poultry sausages. Journal of Food Composition and Analysis, v. 13, p. 915-920, 2000.

PIETRASIK, Z. Binding and textural properties of beef gels processed with $\mathrm{k}$ carrageenan, egg albumin and microbial transglutaminase. Meat Science, v. 63, $p$ 317-324, 2003.

RAHARJO, S.; DEXTER, D. R.; WORFEL, R. C.; SOFOS, J. N.; SOLOMON, M. B.; SHULTS, G. W. Quality characteristics of restructured beef steaks manufactured by various techniques. Journal of Food Science, v. 60, n. 1, p. 68-71, 1995.

RAMIRES, J. A. F. Viva com mais saúde. São Paulo: Instituto Phorte Educação, 2009, $480 \mathrm{p}$.

RESENDE, A. L. S. S. Viabilidade técnica, qualidade nutricional e sensorial de produtos a base de carne de Tilápia (Oreochromis niloticus). 2010. 100f. 
Dissertação (Doutorado), Universidade Federal Rural do Rio de Janeiro. Rio de Janeiro, 2010.

REVERTE, D.; XIONG, Y. L.; MOODY, W. G. Properties of restructured beef steaks from grass- and grain-fed cattle as affected by antioxidant and flavoring agents.

Meat Science, v. 65, p. 539-546, 2003.

RHEE, M. S.; WHEELER, T. L.; SHACKELFORD, S. D.; KOOHMARAIE, M. Variation in palatability and biochemical traits within and among eleven beef muscles. Journal of Animal Science, v. 82, n. 2, p. 534-550, 2004.

RHEE, K. S.; ZIPRIN, Y. A.; ORDONEZ, G.; BOHAC, C. E. Fatty acid profiles of the total lipids and lipid oxidation in prok muscles as affected by canola oil in the animal diet and muscle location. Meat Science, v. 23, p.201-210, 1988.

RIVISK, E. Sensory properties and preferences. Meat Science, v. 36, p. 6777,1994 .

ROBBINS, K.; JENSEN, J.; RYAN, K. J.; HOMCO-RYAN, C.; MCKEITH, F.; BREWER, M. S. Enhancement effects on sensory and retail display characteristics of beef rounds. Journal of Muscle Foods, v. 13, p. 279-288, 2002.

ROBBINS, K.; JENSEN, J.; RYAN, K. J.; HOMCO-RYAN, C.; MCKEITH, F. K.; BREWER, M. S. Consumer attitudes towards beef and acceptability of enhanced beef. Meat Science, v. 65, p. 721-729, 2003.

RODRÍGUEZ-CARPENA, J. G.; MORCUENDE, D.; ESTÉVEZ, M. Avocado, sunflower and olive oils as replacers of pork back-fat in burger patties: Effect on lipid composition, oxidative stability and quality traits. Meat Science,. v.10, 2011.

ROLAN, T. L.; DAVIS, G. W.; SEIDEMAN, S. C.; WHEELER, T. L.; MILLER, M. F. Effects of blade tenderization and proteolytic enzymes on restructured steaks from beef bullock chucks. Journal of Food Science, v. 53, p. 1062-1064, 1110, 1988.

ROMANELLI, P. F.; CASERIL, R.; FILHO, J. F. L. Processamento da carne do jacaré do Pantanal (Caiman crocodilus yacare). Ciência e Tecnologia de Alimentos, Campinas, v. 22, n.1, 2002.

ROWGHANI, E.; ARAB, M.; NAZIF, S. Effect of canola oil on cholesterol and fatty acid composition of egg-yolk of laying hens. International Poultry Science, v. 6, n. 2, p. 11-114, 2007.

RUBENSAM, J. Estudos sobre atividade de calpastatina em carne bovina e obtenção de anticorpo anti GST- calpastatina. 1999. 154p. Dissertação (Mestrado em Veterinária) - Faculdade de Veterinária, Universidade Federal do Rio Grande do Sul, Porto Alegre, 1999. 
RUIZ, C. F.; HIGGINBOTHAM, D.A.; CARPENTER, J.A.; RESURRECCION, A.V.A.; LANIER, T.C. Use of chuck muscle and their acceptability in restructured beef/surimi steaks. Journal Animal Science, v. 71, p. 2654-2658, 1993.

SALDANHA, T.; MAZALLI, M. R.; BRAGAGNOLO, N. Avaliação comparativa entre dois métodos para determinação docolesterol em carnes e leite. Ciência e Tecnologia de Alimentos, v. 24, n. 1, p. 109-113, 2004.

SCHAAKE, S. L.; MEANS, W. J.; MOODY, W. G.; BOYLE, E. A.; AARON, D. K. Boning methods and binders affect bind and sensory characteristics of structured beef. Journal of Food Science, v. 58, n. 6, p. 1231-1236, 1993.

SCHUT, J. Basic meat emulsion technology. In Proceedings of the meat industry research conference. American Meat Institute Foundation, v. 1, p. 1-15, 1978.

SEGURO, K. Microbial transglutaminase and e-( -glutamyl)lysine crosslink effects on elastic properties of kamaboko gel. Journal of Food Science, v. 60, p. 305-311, 1995.

SERRANO, A.; LIBRELOTTO, J.; COFRADES, S.; SA'NCHEZ-MUNIZ, F. J.; JIMÉNEZ-COLMENERO, F. Composition and physicochemical characteristics of restructured beef steaks containing walnuts as affected by cooking method. Meat Science, v. 77, p. 304-313, 2007.

SERRANO, A.; COFRADES, S.; JIMÉNEZ-COLMENERO, F. Characteristics of restructured beef steak with different proportions of walnut during frozen storage. Meat Science, v. 72, p. 108-115, 2006.

SERRANO, A.; S. COFRADES, S.; JIMÉNEZ-COLMENERO, F. Transglutaminase as binding agent in fresh restructured beef steak with added walnuts. Food Chemistry, v. 85, p. 423-429, 2004.

SEIDEMAN, S. C. Utilization of meat and non-meat replacements in restructured products. In: International Symposium of Meat Science and Technology, p.245254, 1982.

SEIDEMAN, S. C.; CROSS, H. R.; SMITH, G. C.; DURLAND, P. R. Factors associated with fresh meat color: A review. Journal of Food Quality, v. 6, p. 211237, 1984.

SGARBIERI, V.C.; Proteínas em alimentos protéicos. São Paulo, Editora Varela, 1996.

SHACKELFORD, S. D.; WHEELER, T. L.; KOOHMARAIE, M. Slice shear force protocol for longissimus, 2003. USDA - ARS U.S. Meat Animal Research Center, disponível em: <www.marc.usda.gov.htm >acesso em 30/01/2012. 
SHAO, C. H.; AVENS, J. S.; SCHMIDT, G. R.; MAGA, J. A. Functional, sensory, and microbiological properties of restructured beef and emu steaks. Journal of Food Science, v. 64, n. 6, 1999.

SHIMP, L. A. Tips on food grade phosphates. Engineering, v. 1, p. 106, 1983.

SMITH, J. J. Functionality of ingredients in restructured products. In: International Symposium of Meat Science and Technology, Nebraska, p.255-264, 1982.

SMITH, G. C., JOHN, H., CARPENTER, Z. L., MATTIL, K. F. AND CATER, C. M. Efficacy of protein additives as emulsion stabilizers in frankfurters. Journal of Food Science, v. 38, p. 849-855, 1973.

SOFOS, J. N. Use of phosphates in low-sodium meat products. Food Technology, v. 40, n.9, p. 52-68, 1986.

SORENSEN, G.; \$ JORGERSEN, S. S. A critical examination as some experimental variables in the 2-thiobarbituric acid (TBA) test for lipid oxidation in meat products. Zeitschrft fur Lebensmittel Untersuchung und forschung, v. 202, p. 205-210, 1996.

SOUCI, S. W.; FACHMANN, W.; KRAUT, H. Food Composition and Nutrition Tables, 1989190, 4th edn. Weissenchaftliche Verlagsgellschaft mbH, Stuttgart, Germany, 1989.

STIKA, J. F.; XIONG, Y. L.; SUMAN, S. P.; BLANCHRD, S. P.; MOODY, W. G. Frozen storage stability of antioxidant-treated raw restructured beef steaks made from mature cowS. Meat Science, v. 77, p. 562-569, 2007.

STIKA, J. F.; SUMAN, S. P.; XIONG, Y. L. Frozen storage stability of vacuumpackaged precooked restructured steaks manufactured from mature cow beef. LWT - Food Science and Technology, v. 41, p.1535-1540, 2008.

STONE, H.; SIDEL, J. L. Affective testing. In: Sensory evaluation practices. 2 ed. California: editora, p.84, 94, 1992.

SZCZESNIAKI, A. S.; TORGESON, K.W. Methods of meat texture measurement viewed from background of factors affecting tenderness. In C.O. CHICHESTER, E. M. MRAK \& G. F. STEWART (eds.). Advances in food research. New York and London: Academic press, p. 33-165, 1965, v. 14, p. 33-165.

SWERN, D. Composition and characteristics of individual fats and oils. In D. Swern (Ed.), Bailey's industrial oil and fat products (3 ed.). New York: Interscience Publishers, 1964, p. 165- 248, cap. 6.

TARLADGIS, B. G.; WATTS, B. M.; YOUNATHAN, M. T. A distillation for the quantitative determination of malonaldehyde in rancid foods. Journal of the 
American Oil Chemist's Society. v. 37, p. 44-48, 1960.

TÉLLEZ-LUIS, S.; URESTIS, R. M.; RAMÍREZ, J. A.; VÁZQUEZ, M. Low-salt restructured fish products using microbial transglutaminase as binding agent. Journal of the Science of Food and Agriculture, v. 82, p. 953-959, 2002.

TERRA, N. N.; BRUM, M. A. R. Carne e seus derivados: técnicas de controle de qualidade. São Paulo: Nobel, 1988. 119 p.

TEYE, G. A.; WOOD, J. D.; WHITTINGTON, F. M.; STEWART, A.; SHEARD, P. R.. Influence of dietary oils and protein level on pork quality 2 . Effects on properties of fat and processing characteristics of bacon and frankfurter-style sausages. Meat Science, v. 73, p. 166-177, 2006.

TOMM, G.O, Tecnologia para Cultivo de Canola no Sudoeste de Goiás. CARAMURU, v. 34. p, 2004.

TOMPKIN, R. B.; CHISTIANSEN, L. N.; SHAPARIS, A. B.. Antibotulinal role of isoascorbate in cured meat. Journal of Food Science, v. 43, p. 1368-1370, 1978.

TOWNSEND, W. E.; ACKERMAN, S. A.; WITNAUER, L. P.; PALM, W. E.; SWIFT, C. E. Effects of types and levels of fat and rates and temperatures of comminution on the processing and characteristics of frankfurters. Journal of Food Science, v. 36, p. 261-265, 1971.

TRINDADE, M. A.; NUNES, T. P.; CONTRERAS-CASTILLO, C. S.; FELÍCIO, P. E.. Estabilidade oxidativa e microbiológica em carne de galinha mecanicamente separada e adicionada de antioxidantes durante período de armazenamento a -18 ${ }^{\circ} \mathrm{C}$. Ciência e Tecnologia.de Alimentos, Campinas, v. 28, p. 1, p. 160-168, 2008.

TROUT, G. R.; SCHIMIDT, G. R. Effect of phosphate type and concentration, salt level and method of preparation on binding in restructured beef rolls. Journal of Food Science, v. 49, p. 687-694, 1984.

TROUT, G.R. Biochemistry of lipid and myoglobin oxidation in post mortem muscle and processed meat products: effect on rancity. In: International Congress of Meat Science and Technology, 49, Brazilian Congress of Technology, 2, 2003. Campinas. Brazilian Journal of Food Technology. v. 6, p. 50-55, 2003. Edição especial.

UNIVERSIDADE DE CAMPINAS. Tabela brasileira de composição de alimentos. 2. ed. Campinas: NEPA-UNICAMP, 2006. 113p

VAN-HEKKEN, D. L., STRANGE, E. D. Functional properties of dephosphorylated bovine whole casein. Journal of Dairy Science, v. 76, n. 5, p. 3384-3391, 1993.

VELHO, J. P.; BARCELLOS, J. O. J.; LENGLER, L.; ELIAS, S. A.; OLIVEIRA, T. E. 
Disposição dos consumidores porto-alegrenses à compra de carne bovina com certificação. Revista Brasileira de Zootecnia, v. 38, n. 2, p. 399-404, 2009.

VYNCKE, W. Direct determination of the thiobarbituric acig value in trichloracetic acid extracts of fish as a measure of oxidative rancidify. Fatte Seifen

Anstrichmittel, v. 72, p. 1084-1087, 1970.

VYNCKE, W. Evaluation as direct thiobarbituric acig value in trichloracetic acid extraction method for determining oxidative rancidify in mackerel. Fatte Seifen Anstrichmittel, v. 77, p. 239-240, 1975.

XIONG, Y. L. Role of myofibrillar proteins in water-binding in brine-enhanced meats. Food Research International, v. 38, p. 281-287, 2005.

ZORBA, Ö.; KURT, S. The effects of different plant oils on some emulsion properties of beef, chicken and turkey meats. International Journal of Food Science and Technology, v. 43, p. 229-236, 2008.

WATANABE, A.; DALY, C. C.; DEVINE, C. E. The effects of ultimate $\mathrm{pH}$ of meat on tenderness changes during ageing. Meat Science, v. 42, p. $67-78,1996$.

WESTPHALEN, A. D.; BRIGGS, J. L.; LONERGAN, S. M. Influence of pH on rheological properties of porcine myofibrillar protein during heat induced gelation. Meat Science, v. 70, p. 293-299, 2005.

WHEELER, T. L.; SHACKELFORD, S. D.; KOOHMARAIE, M. Shear force procedures for meat tenderness measurement. Roman L. Hruska U.S. Marc. USDA, Clay Center, NE, 2001.

YAN, G. Enhancement of microbial transglutaminase production by Streptoverticillium mobaraense: application of a two-stage agitation speed control strategy. Process Biochemistry., v. 40, p. 936-968, 2005.

YANG, C. C.; CHEN, T. C. Effects of refrigerated storage, pH adjustment, and marinade on color raw and microwave cooked chicken meat. Poultry Science,v. 72, p. 355-362, 1993.

YOKOYAMA, K.; NIO, N.; KIKUCHI, Y. Properties and application of microbial transglutaminase. Apply Microbial Biotechnology, v. 64, p. 447-454, 2004.

YOUSSEF, M. K.; BARBUT, S. Effects of protein level and fat/oil on emulsion stability, texture, microstructure and color of meat batters. Meat Science, v. 82, p. 228-233, 2009.

YOUSSEF, M. K.; BARBUT, S. Fat reduction in comminuted meat products-effects of beef fat, regular and pre-emulsified canola oil. Meat Science, v. 87, p. 356-360, 2011. 
YOUNG, L. L.; LYON, C. E.; SEARCY, G. K.; WILSON, R. L. Influence of sodium tripolyphosphate and sodium choride on moisture-retention and textural characteristics of chicken breast meat patties. Journal of Food Science, v. 52, p. 571-579, 1987. 


\section{ANEXO 1}

Ficha de teste sensorial

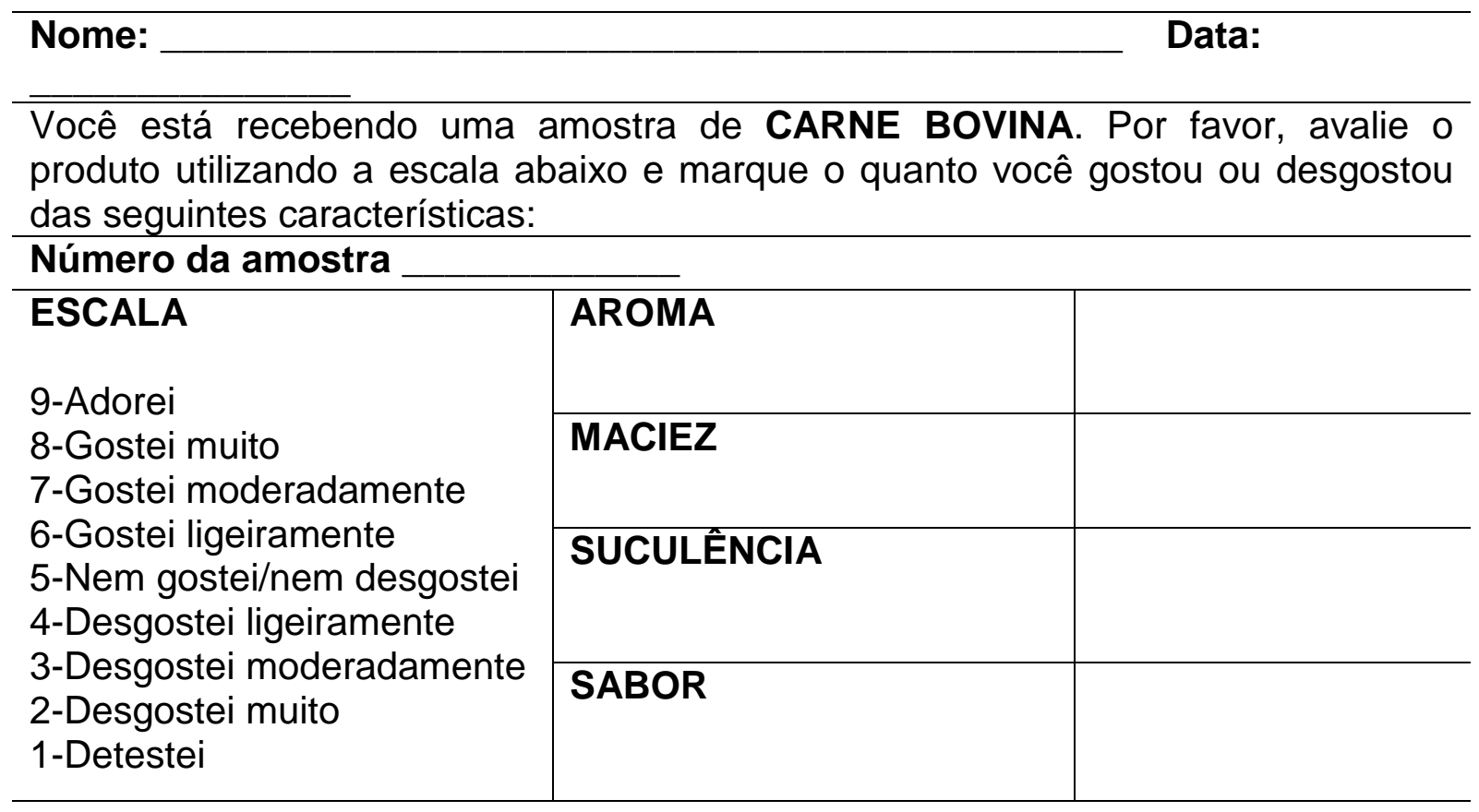

